
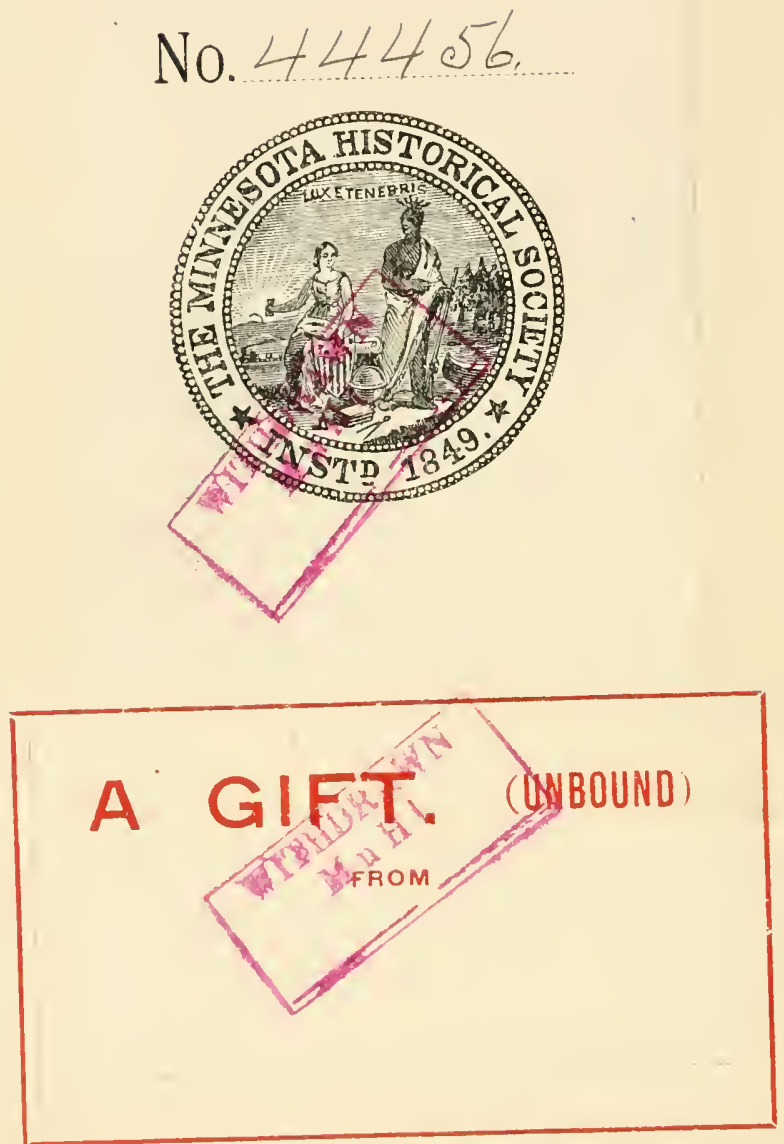


2. $257=$

SFILF

USL

$0 c / 11968917$ 
Digitized by the Internet Archive in 2008 with funding from Microsoft Corporation 
A RGENTINE REPUBLIC

MINISTRY OF AGRICULTURE

Immigration Department

The Immigration Offices

\author{
AND \\ Statistics from 1857 to 1903 \\ - - - \\ I N F OR MATION \\ FOR THE \\ Universal Exhibition of St. Louis (U. S. A.)
}

The Head Offices are situated in Alsina Street N.o 624 Buenos Aires, where information can be obtained either verbally or by correspondence in different languages by those who wish to establish themselves in the

Argentine Republic

\title{
BUENOS AIRES
}

Printing Establishment of the Argentine Weather Bureau

1904 



\section{Duties of the Immigration Department subject to which immigrants can avail themselves of the benefits of the Im- migration Law}

The Immigration Department under the control of the Ministry of Agriculture, has the direction of all relating thereto in the Argentine Republic, and is organized to correspond to the special services related to it, which are ruled by the organic' Law of $16^{\text {th. }}$ October $1 S 76$.

\section{MaNaging STAFF in BUENOS AIRES}

The managing staff is composed of a Chief and a head clerk, and further more the Secretary's Department, Archives, Accountants Department, Treasury, Statistics, Interpreters office for verbal information and foreign correspoudence, Disembarking office, Labour and Forwarding office, Immigration Hotel, Hospital and Medical service, and Post and Telegraph office, all of which are established in Buenos Aires.

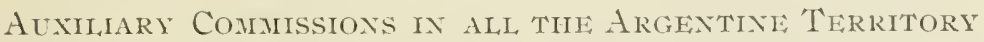

To attend the requirements of the service in the Interior, there are 42 Auxiliary Commissions established in the principal cities and towns of importance.

(Articles 6, 7 and 8 , Chapter III of the Law.) 


\section{ARChives}

In the Archives of the Department, a careful Register is kept of all administrative papers, studies, observations and documents of ships transporting immigrants, and a list of all those entered since the year 1857 ,

\section{Accountant's and Treasury Departinents}

The Accountant's Department and the Treasury have under their charge the financial part of the administration and keep account of all amounts spent in lodging and transport of immigrants and their baggage, payment of wages to employés and other expenses (Article 3 paragraph I3.)

\section{STATISTICS}

The Statistical Office keeps minute statistics of the immigrants arriving in the country, classifying annually and monthly the arrivals and departures of steamers, stating date, flag, number of passengers and immigrants with a summary of the immigration movement; steamers inspected, ports of procedure, classification of immigrants according to nationality, profession, sexe, age; monthly, anuually and quinquennially; sexagenarians entered; births and deaths on board, immigrants entered at the Hotel and settling of immigrants in the interior.

\section{INTERPRETERS OFFICE}

In the Interpreters office there are employés who speak several languages; verbal information is given to all immigrants who ask for it. It provides information regarding lands offered for sale and has charge of the foreign correspondence.

\section{LABOUR AND FORWARDING OFFICE}

The Labour and Forvarding Office receives inquiries for workmen from all parts of the country, and, according to such inquiries, undertakes the placing of the immigrants who come to the Hotel, asking for lodging and employment. This office provides the imnigrants with the information they 


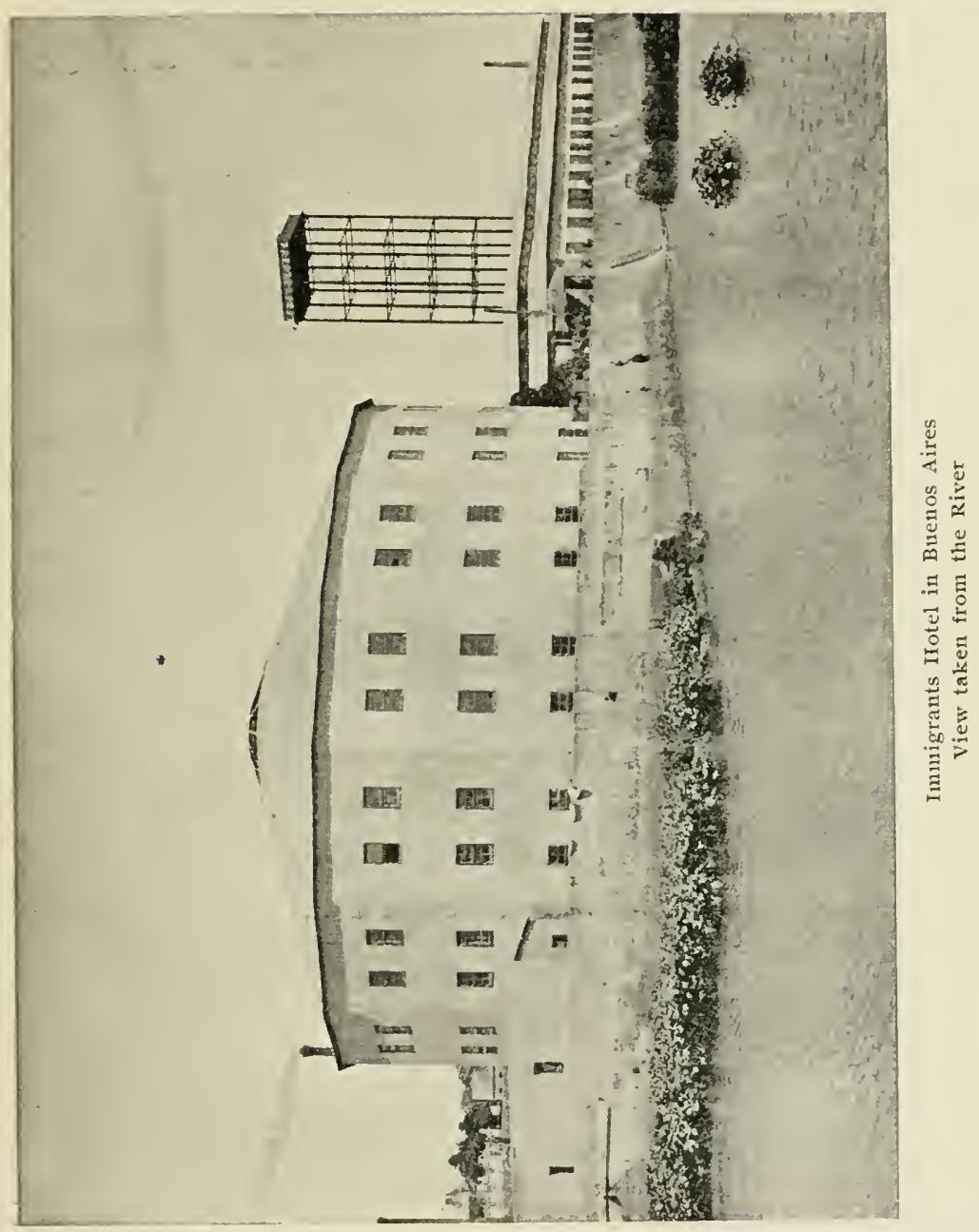


solicit about the different districts of the country, means of communication, wages etc. It undertakes the forwarding of the immigrants and their distribution in the regions to which they desire to be sent, and all other work connected with these services. (Articles 9, IO and II and 48 to 54 of the Law.)

\section{LANDING SUPERINTENDENTS}

The Disembarking Office consits of Inspectors who go on board the vessels to receive and classify the immigrants, and see if the ships have complied with the conditions of the Law regarding ressels carrying immigrants, and also to impede the entry of those which said Law prohibits (Chapter VI, Articles Is to 37 and the Regulation agreed upon of $4^{\text {th. Narch } 1880 .)}$

\section{IMMIGRANTS HOTEL OR HOME:}

Those who avail themselves of the benefits of the Law, are lodged in the Immigrants Hotel whilst work is procured for them, which is done immediately.

The Hotel is provided with the accommodation and service necessary to meet this requirement.

It has separate dormitories for each sex, ample dining rooms, lavatories, and a police service to contribute in maintaining order and also a corps of firennen to prevent conflagrations. (Chapter VIII of the Law, Articles 42 to 47 .)

\section{HOTEL INTERPRETERS}

The Hotel is provided with interpreters of all languages, to mediate between the immigrants, and the Hotel employés and the Labour and Forwarding Office.

\section{Medical Assistancli}

Sick immigrants and nembers of their fanilies are attended at all hours by the Medical staff of the Hotel, which is further more provided with an Infirmary supplied with all the most necessary medicanents. 


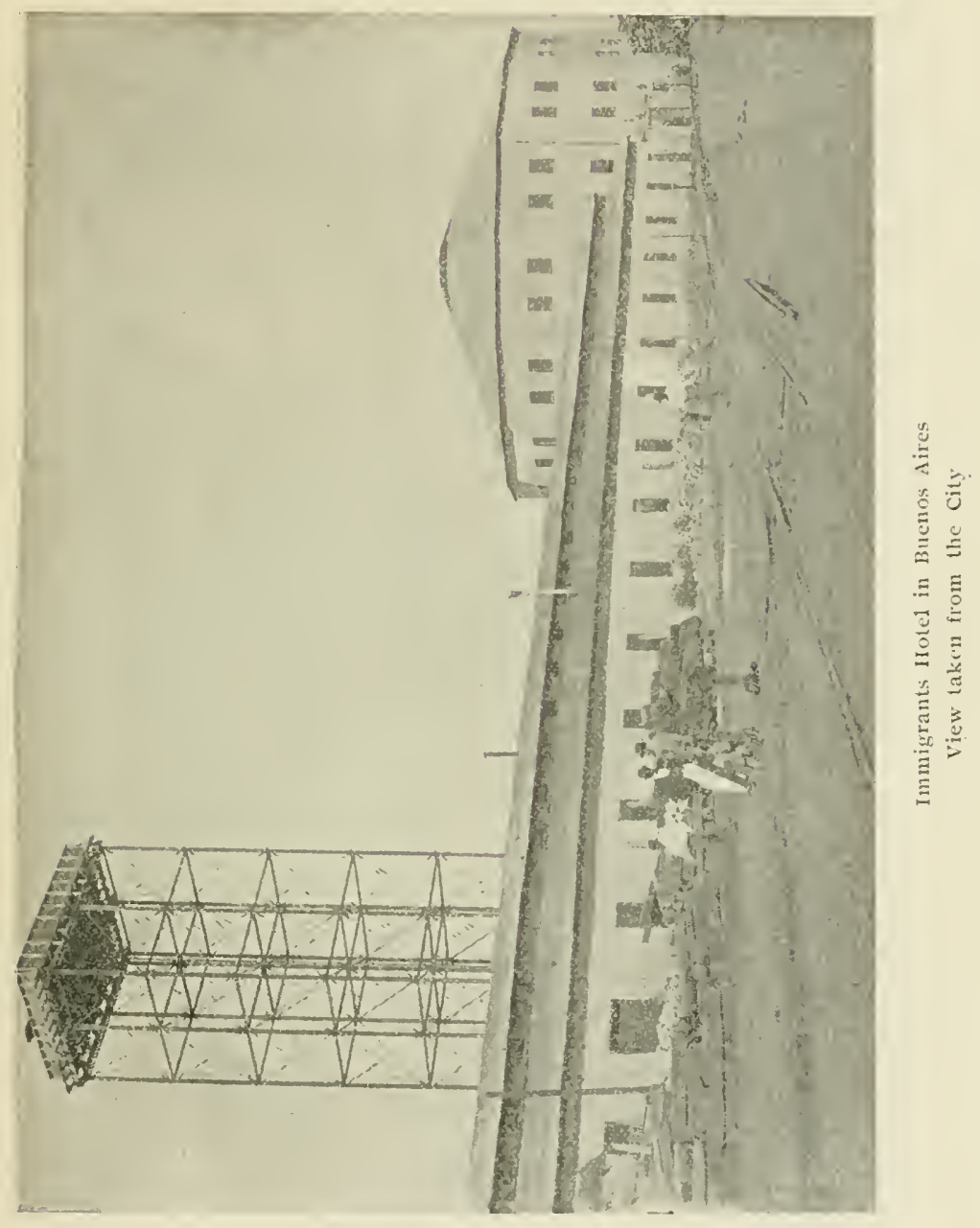




\section{Customs SeRvice}

To facilitate the despatch of immigrants baggage, the Custom House has an office in the Hotel which carrys out all the corresponding operations.

By means of this organization, which meets all the exigencies of the immigration in the Argentine Republic, the immigrants are given all the advantages accorded by the Immigration Law hereunder transcribed.

\section{ARTICLES OF THE IMMIGRATION LAW IMPOR'TANT FOR IMMIGRAN'TS TO KNOW} CONCERNING THE LABOUR OFFICES

Art. 9.-The Immigration-Office in Buenos Aires and the Commissions at their various head quarters shall, whenever it may be necessary, have placed under their direct control a Labour and Employment-Office to be served by such a number of clerks as may be fixed in the Budget.

Art. 10.- These Offices are bound and empowered:

I. To attend to such applications of teachers, artisans, journeymen or workmen as may be sent in to them.

2. To secure advantageous terms for the employment of inmigrants, and to see that such employment be given by people of good repute.

3. To intervene at the request of the immigrants in such agreements as to work as said immigrants may make, and to see to their strict observance on the part of masters.

4. To write down in a special register the number of the procured employments, mentioning the date, the sort of work, the conditions of the contract, and the names of the persons that niay have intervened in it.

Art. I1.-At such places where there are no EmploymentOffices, the duties incumbent on these shall be carried out by the Commissions of In111igration. 


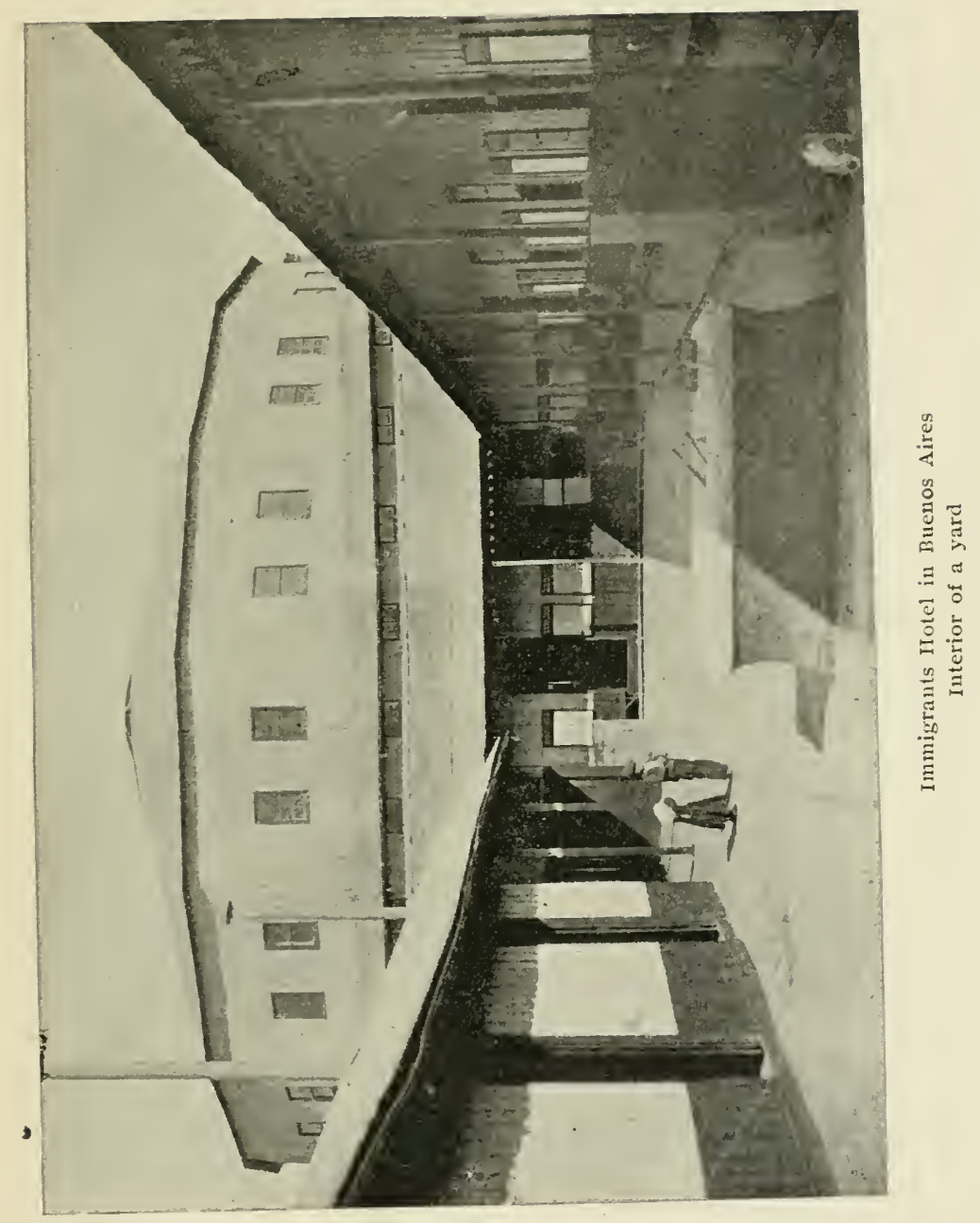




\section{CHAPTER V.}

Art. 12. - By the effects of this Law, every foreigner under sixty years of age, whether he be a journeyman, artisan, labonrer, tradesman or teacher, who proves his morality and capacities, shall be considered an immigrant, on arriving in the Republic, to establish himself in it, either in a steamer or sailing vessel, paying his own $2^{\text {nd. }}$ or $3^{\text {rd. class }}$ passage, or having it paid by the State, the Provinces, or by private societies protecting immigration and colonisation.

Art. I5.- Those persons to whom these conditions apply and who do not desire to profit by the advantages offered to the immigrants, shall let it be known to the captain of the ship at the moment of their embarking, when he will note it in the ship's register, or communicate it to the maritine authorities of the landing port: in this case, those persons shall be considered as simple travellers.

This disposition is not meant for those immigrants who may come engaged in this capacity for the colonies or other places in the Republic.

Ari. I4.-Every immigrant on giving sufficient proof of his good conduct and fitness for any occupation, art or usefull trade, will be entitled, on his arrival to the following special privileges:

I. To be boarded and lodged at the expense of the $\mathrm{Na}$ tion during the time fixed by articles 45,46 and 47 .

2. To have employment given him in such calling or trade as there nuay be in the country, and which he may prefer.

3. To be transported at the expense of the Nation to such locality in the Republic as he mar select for his residence.

4. To import free of chuty articles for personal use, clothing, furniture for domestic purposes, agricultural implements, tools, utensils, instrunents of such arts and tracles as they niay exercise, and one fowling piece to each adult immigrant, of such value as may be fixed by the Iixecutive.

Art. 15,-The dispositions of the preceding article sliall 


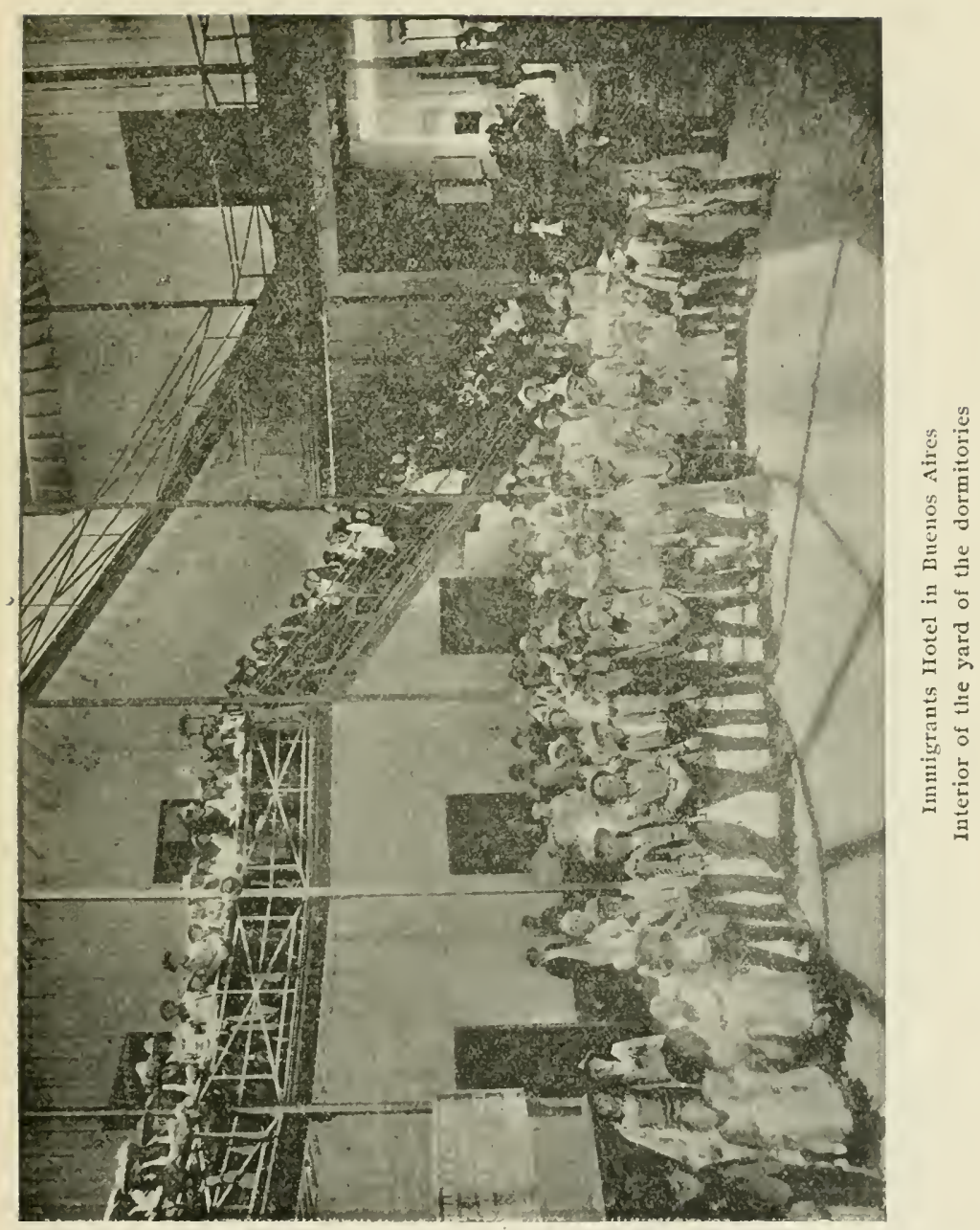


be extended as far as they can be applied, to the wives and to the children of the immigrants, if grown up, provided they can give proof of their morality and industrious aptitudes.

Art. 16. - The good conduct and industrious capacities of the immigrants can be proved by certificates given by the Consuls or Inmigration Agents of the Republic abroad, or by a certificate frowl the authorities of the immigrant's residence, legalized by the said Consuls or Immigration Agents. of the Republic.

\section{CHAPTER VIII.}

\section{CONCERNING THE LODGING AND BOARDING OF THE} IMIIGRAN'TS

Art. 42.- In the cities of Buenos Aires, Rosario, and at all such others where, owing to the number of immigrants, it may be necessary, there shall be a house for their temporary lodgment.

Art. 44.-At such places where there should not be any houses for the accommodation of immigrants, the respectiveCommissions shall proceed to board and lodge the same in public hotels or in other suritable ways.

Art. 45.-Imnigrants shall be entitled to suitable board and lodging, at the expense of the Nation, for five days after landing.

Art. 46.-In case of serious illness which should render it impossible for them to remove to another habitation, at the expiration of the said five days, the expense of the succeeding board and lodging shall continue to be met by the State, as long as the said illness continues.

Except in such cases, the continuance of immigrants at the Establishment for more than five days shall be at their own expense, at the rate of half a national gold dollar a day for every person more than 8 years old, and 25 cents for every child under that age.

Art. 47.-The regulations contained in the preceding articles do not include immigrants having contracts with the Goverment in connection with the Colonies. All such will be entitled to board and lodging free of charge until trans-ported to their destination. 


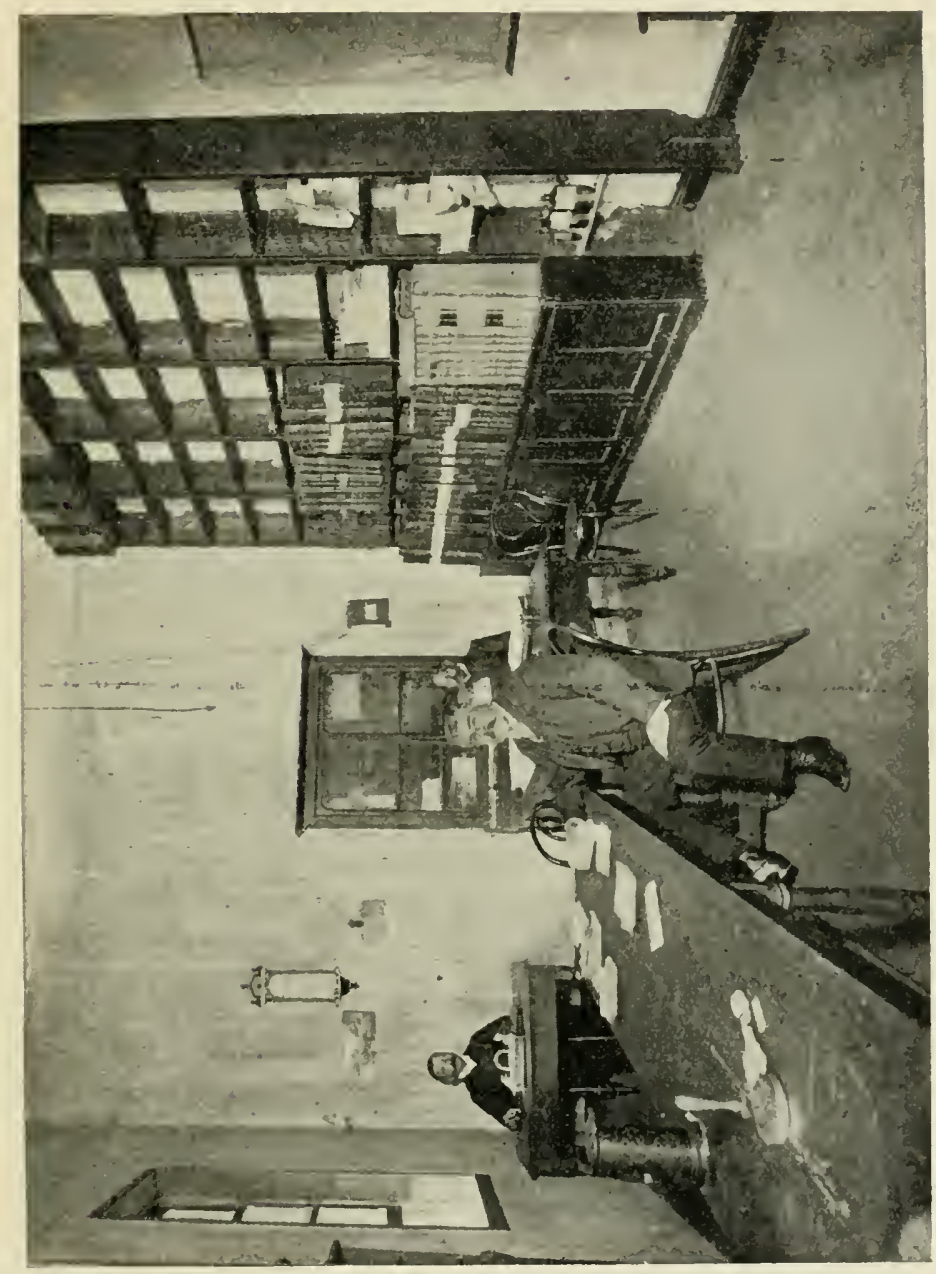

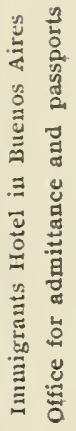




\section{CHAPTER IX.}

. CONCERNING THE TRANS ORT TO THE PROVINCES AND THE EMPLOYIENT OF THE IMMIGRAN'TS

Art. 48.-The Employment-Offices or the InmigrationCommissions in their stead, shall use their best endeavours to provicle immigrants with employment in such art, trade or calling as the may prefer.

Art. 49.-Such employment shall be procured if possible within five days after the immigrant's arrival, and on as favourable terms as possible.

Art. 50.-The Employment-Offices or the InmigrationCommissions in their stead shall, at the request of the interested parties, intervene in such contracts for employment as they may make, with a view to securing their fulfillment for the immigrant.

Art. 51.-Any immigrant who should prefer to fix his residence in any of the interior Provinces of the Republic, or at any of its Colonies, will be at once transported with his family and luggage to such place, as he may select, free of all charge.

Art. 52.-In case of an immigrant going to the Provinces, he will be entitled on arrival at his destination, to be lodged and boarded for ten days by the Immigration-Commission. At the expiration of this time, he shall pay half a national gold dollar a day for every person over 8 years old, and 25 cents for every child under that age, except in case of illness, when he would continue to be maintained at the expense of the Government as long as the said illness lasts.

Art. 54. - The immigrants can on no pretence whaterer, profit by the privileges granted by the preceding articles, to pass through the territory of the Republic to a foreign conntry, under penalty of repaying all the expenses that have been occasioned for their passage, landing, board, lodging and transport. 


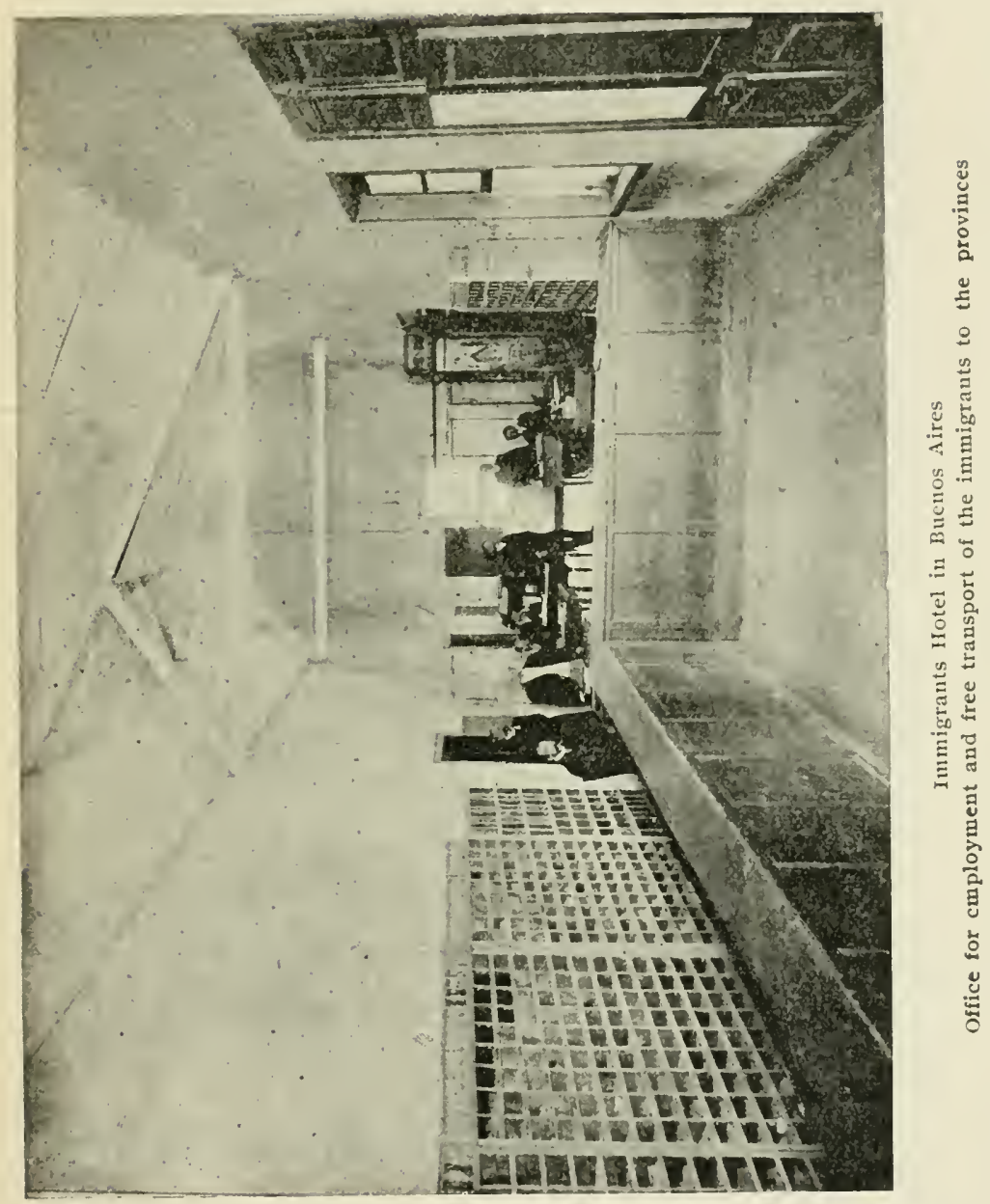




\section{Reception of immigrants in the Argentine Republic.}

THE IMIIGRANT INSPECTION AND ITS REASON

Each ship that arrives in the conntry bringing inmi-

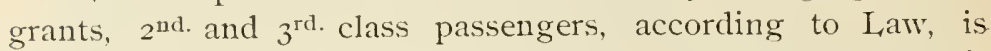
visited and inspected by a Commission comprising the Inmingration Inspector, Board of Health doctor and Coast Guard officer, who examine the hygiene and healthiness of the ship, accommodation, provisioning during the voyage, supply of medicines, and as to whether a doctor or chemist is carried; if or no a greater number of passengers were carried than the accommodation allows; if the measurements of the deck, sparedeck and of the berths are in accordance with the Law; if there is sufficient ventilation, supply of firehose and cooking utensils, life belts and life boats; if there are passengers with contagious diseases; if passengers have been embarqued at ports where there is an epidemic; if any part of the cargo is inflamable or unhealthy, and, finally, receive any protest of the passengers of bad treatment and obtain from the Captain the documents he should deliver, showing cognoscence of the Immigration Law, and any incidents that have happened on the royage. This is done in the interest of the immigrants.

RECEIVING THE IMMIGRAN'TS

The imuigrants are carefully questioned and classified to find ont their trades and means, note being taken of those who do not wish to come under the Inmigration Law, their passports then being stamped «passenger only», as also are stamped «former resident». the passports of those who come under that heading.

Once the passports revised by the officials, tlose immigrants admited nuder the Law, are handed over to the receiving officials of the Imnigrants Hotel who attend to then, placing them in trans, which take then to the Hotel. The baggage is taken on trucks to the same place by the Hotel porters. 


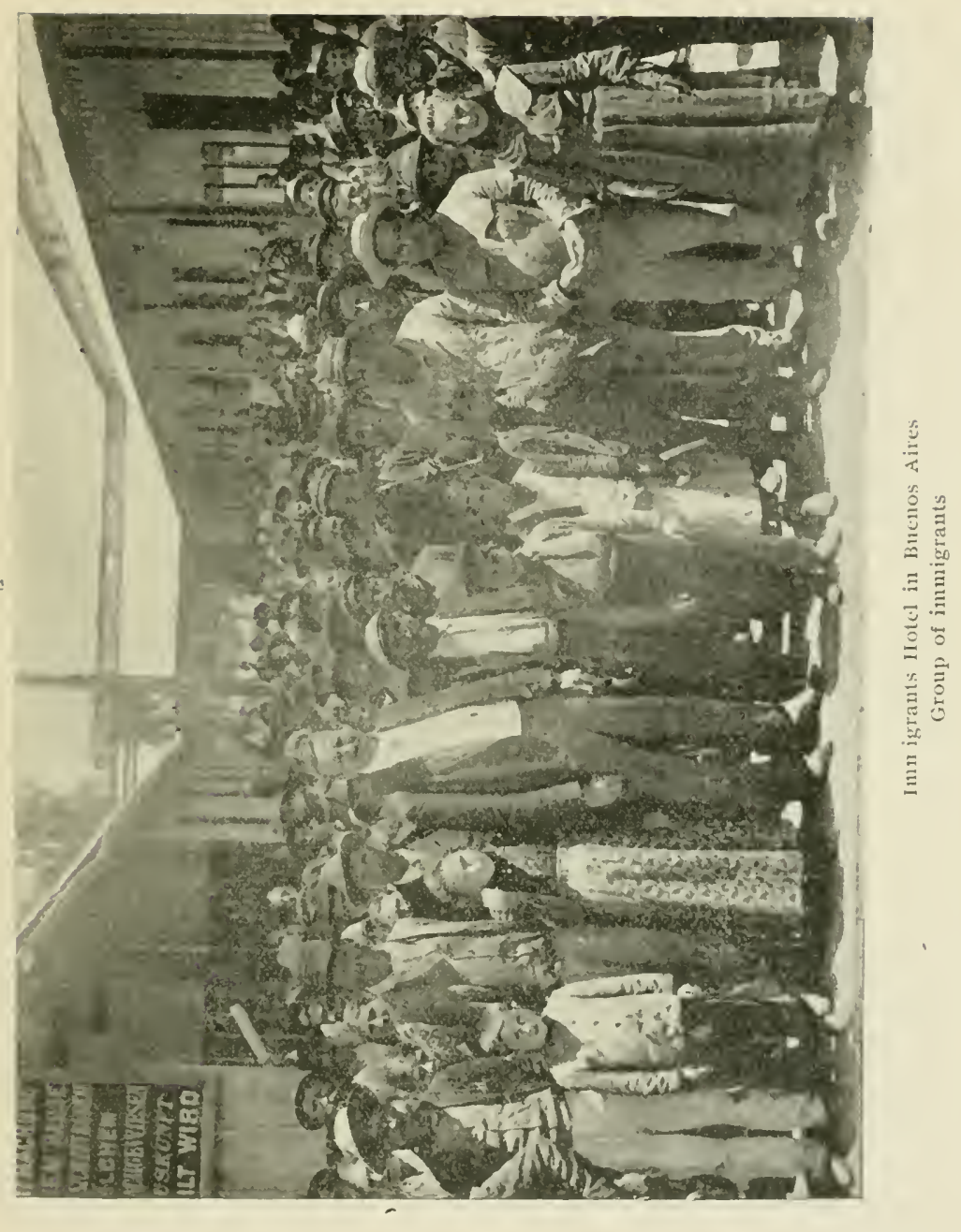


FREE LODGING

Arriving at the Hotel, the names of the immigrants are entered in the Hotel register and they are given a lodging ticket valid for five days, which can be prolonged in case of sickness. The immigrants are comfortably lodged, the women and children in separate rooms to the men. The baggage is taken by the Hotel porters to a deposit where it is revised by the Custom House Officers, specially.

\section{FREE BOARD}

The rations given to the inmmigrants are of the best, and in the following proportions per day, per adult: meat 600 grams, bread 500 grams, potatoes, carrots or cabbage (alternately) I 5o; rice, maccaroni, or beans (alternately) Ioo; sugar 25 and coffee 10 grams; $111 \mathrm{ilk}$ is given to the children. 'The food is cooked by steam and is served by the Hotel attendants in a large dining room.

\section{MEDICAL ATTENDANCE}

There is an Infirmary in the Hotel where patients are carefully attended; children as well as adults can be vaccinated. There is a staff of doctors, students, sickuurses, and a chemist's fully equiped with medicines and disinfectants.

\section{GOVERNMENT EMPLOYMENT OFFICE}

On arrival, the immigrants are questioned as to what part of the country they wish to go, and are offered work by the Employment Office, in accordance with the inquiries for workmen received, full information of which, of wages paid and other conditions are carefully entered 11 in books kept for that purpose. If there are no enquiries for workmen in the particular trade of an immigrant looking for employment, this Office undertakes to find him work by either directing him to Works and Factories or by telegraphing enquiries to the Interior. Immigrants are warned, should they wish to go to any part of the country where there is no opening for one in their trade.

No persuasion is used to induce immigrants to go to any particular part of the country, it is left to them to decide: 


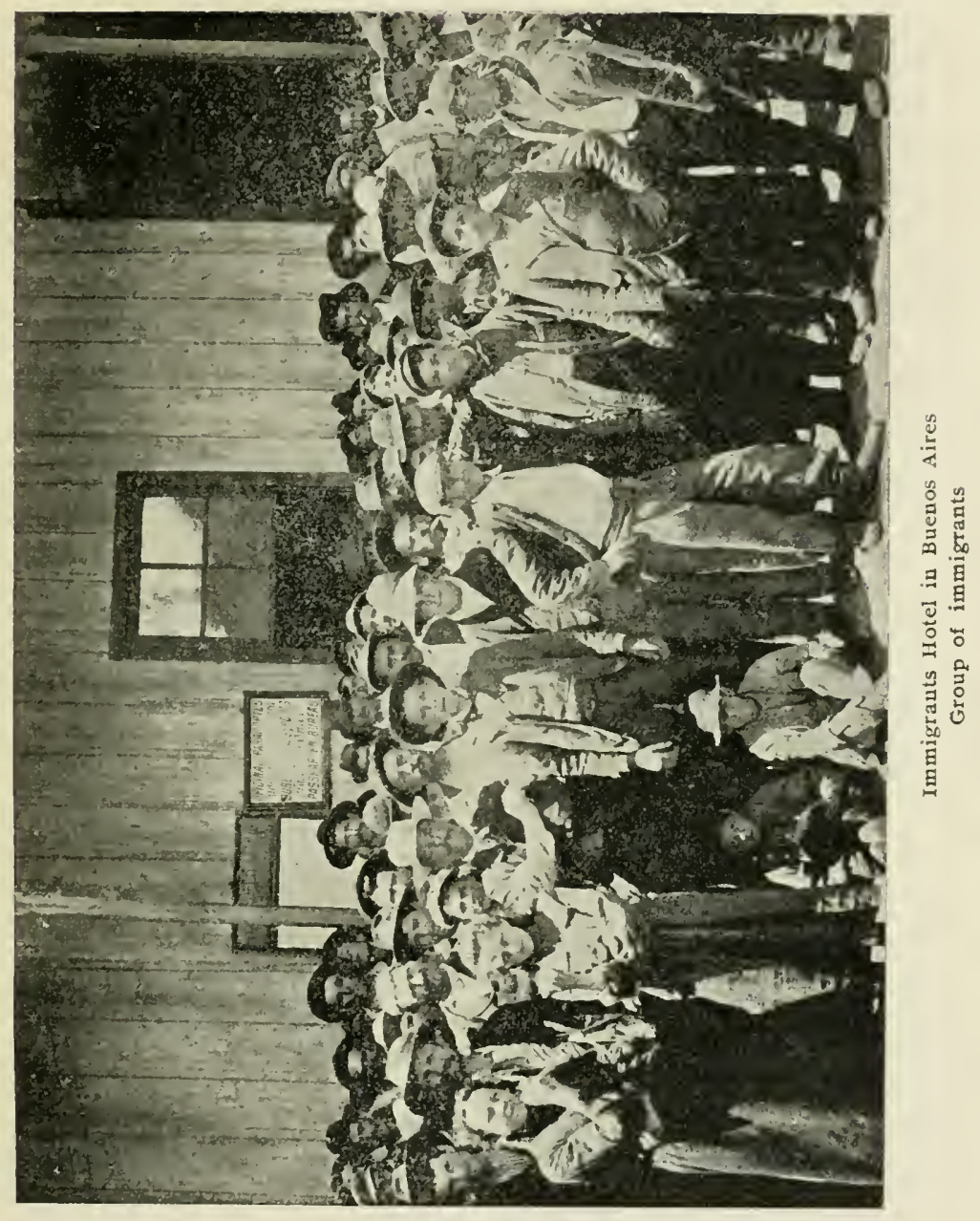


FORWARDING AND RECEINING FREE

The innmigrants placed up country or who wish to join their relations, are taken care of by forwarding Agents who remit their luggage properly labeled, note down the immigrants so forwarded, provide them with tickets and see them on to the train or river steamers.

ARRIVING AT THE PROVINCES AND POINTS OF DESTINATION

The immigrants who go to the Provinces or National Territories to be settled, are met on arrival of the train by the Secretary of the Branch Office, boarded and lodged for ten days until they are settled or leave for some fixed destination. If they should hove to change trains, they are looked after by this Officia! in the same way as in the Federal Capital, from the arrival of one train until the departure of the one in which they continue their journey.

POST AND TELEGRAPH OFFICE

For the better handing of the immigrants correspondence and in order that the Head Office and National Employment Office can transmit without delay, orders and instructions all over the Republic, there is a Post and Telegraph Office in the Innnigration Hotel.

\section{S'TATISTICAY, RE'TURNS}

The four following returns, summarize the Argentine Immigration morement from I 857 to 1903 .

In those relating to the entry and nationality of immigrants, the information corresponding to the years ruming from 1857 to 1903 is given, and in those which refer to their trades and forwarding to the interior, the information has been taken corresponding to the last decade, this lapse of time being sufficicntly demostrative. 


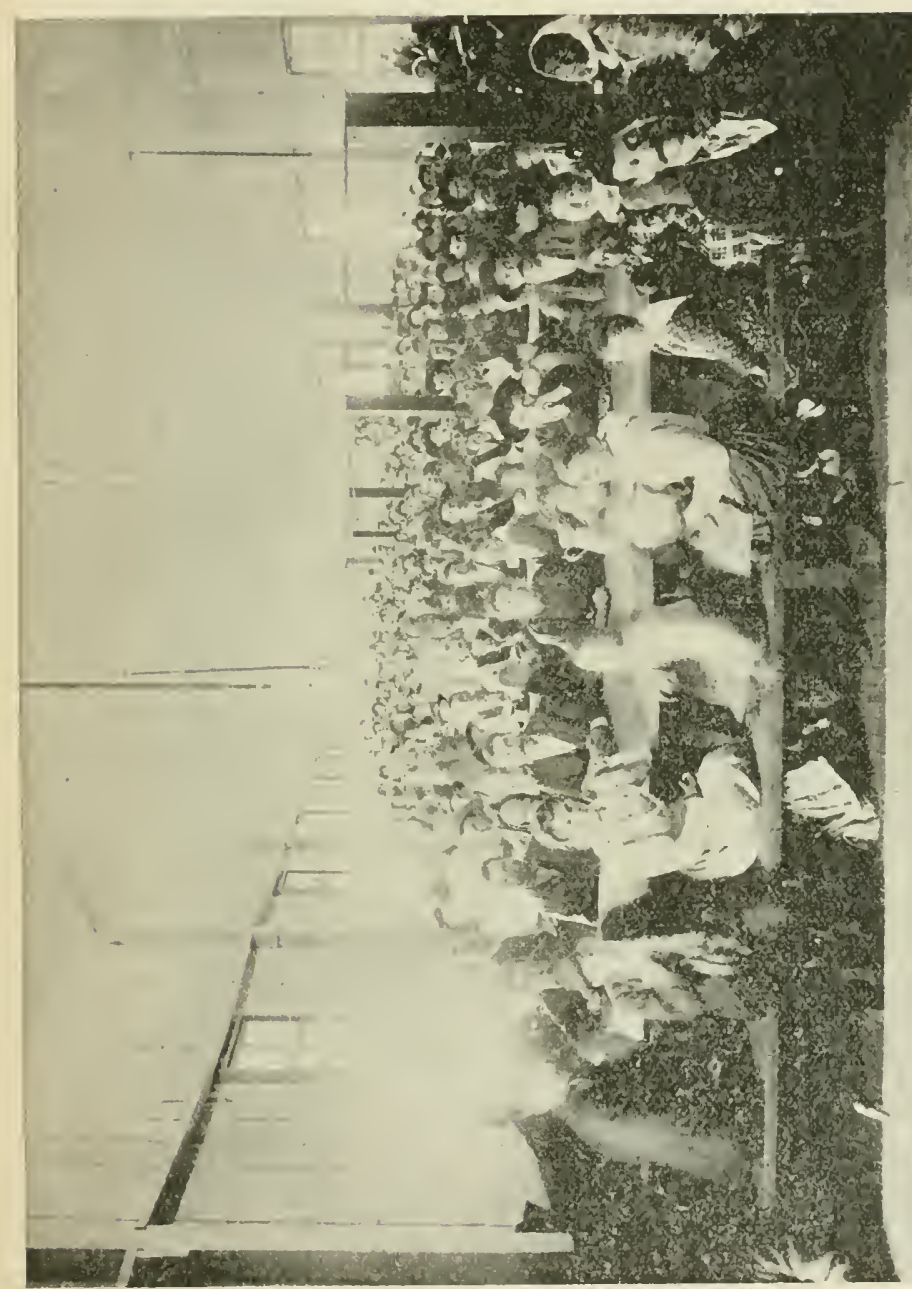

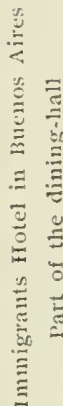




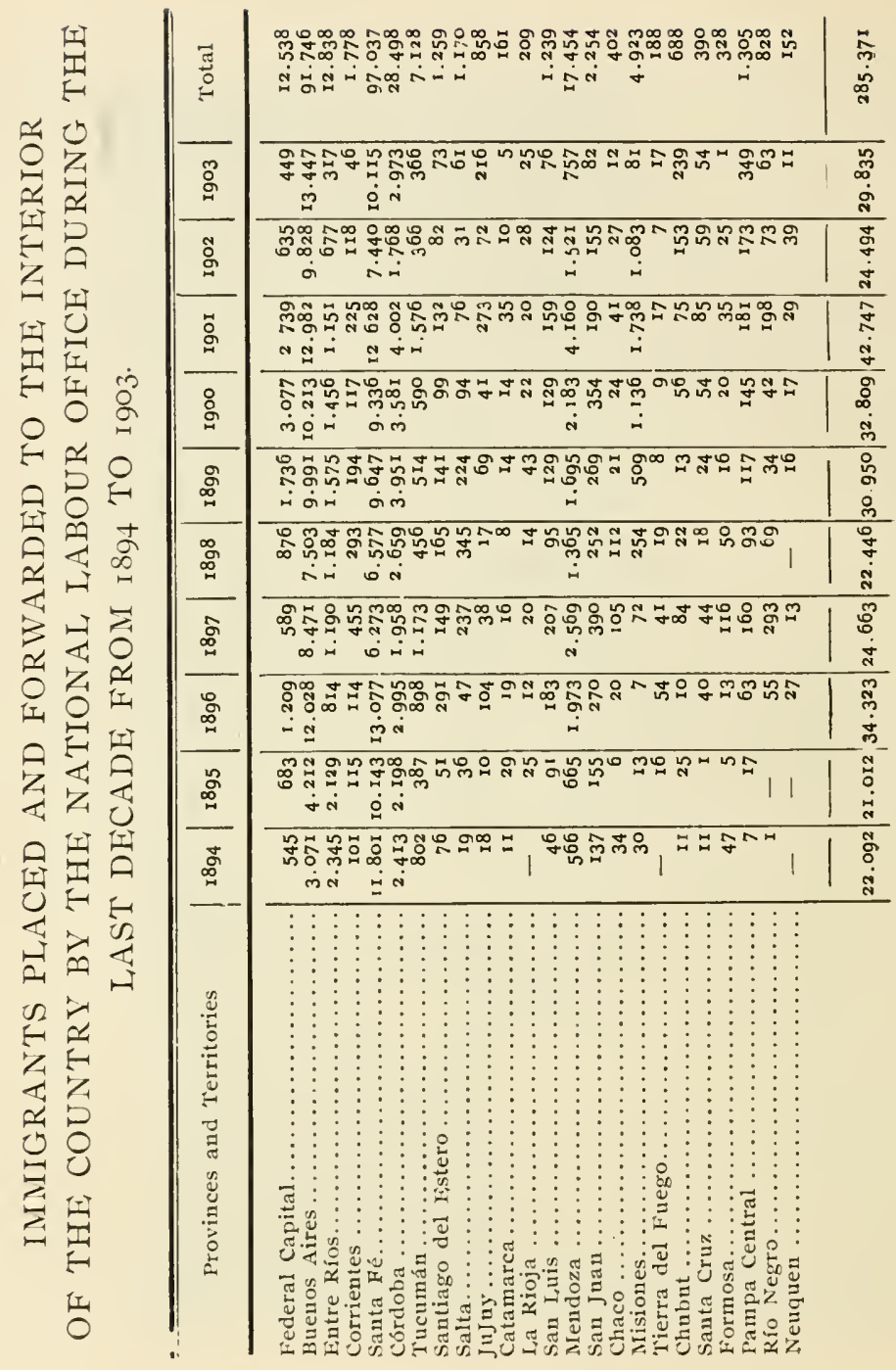




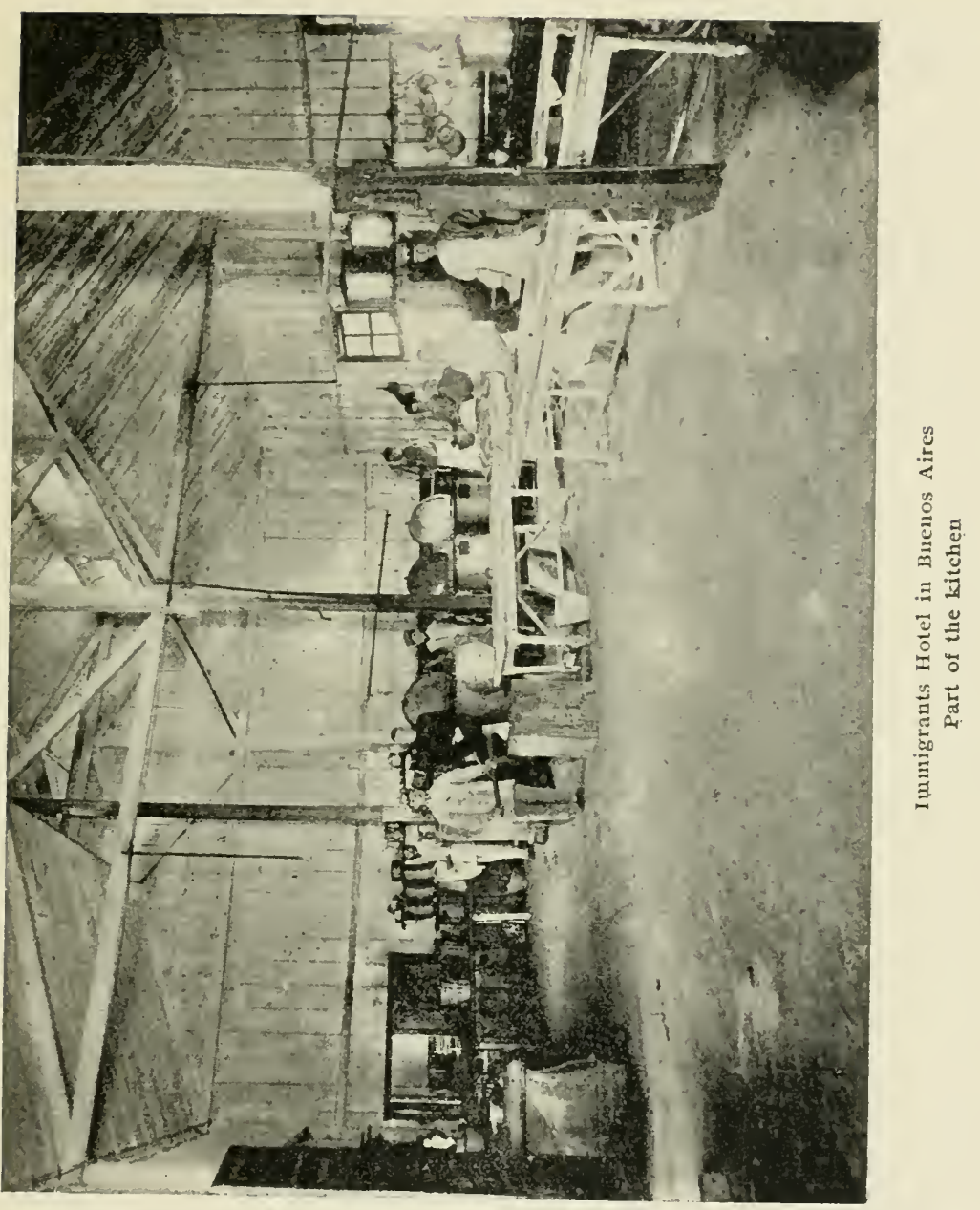




\section{IMMIGRATION FROM}

COUNTRIES BEYOND THE SEA AND MONTEVIDEO

I 857 to 1903 .

\begin{tabular}{|c|c|c|c|}
\hline Years & $\begin{array}{c}\text { Countries } \\
\text { beyond the sea }\end{array}$ & Nontevideo & Total \\
\hline 1857 & ' $4.95 \mathrm{I}$ & & $4.95 \mathrm{I}$ \\
\hline 1858 & $4.65^{8}$ & & 4.658 \\
\hline I 859 & 4.735 & & 4.735 \\
\hline I 860 & 5.656 & & 5.656 \\
\hline I S6 I & 6.301 & & 6.301 \\
\hline I 862 & 6.716 & & 6.716 \\
\hline I 863 & 10.408 & & 10.408 \\
\hline I 864 & 11.682 & & I I. 682 \\
\hline I 865 & II. 767 & & $\begin{array}{l}\text { I. } .767 \\
13.606\end{array}$ \\
\hline $\begin{array}{l}x 866 \\
x 867\end{array}$ & $\begin{array}{l}\text { I } 3.696 \\
\text { I } 3.22 .5\end{array}$ & 3,82 I & $\begin{array}{l}3.090 \\
17.046\end{array}$ \\
\hline I 868 & 25.919 & $3 \cdot 3$ I 5 & $29.23 t$ \\
\hline I 869 & $28.95^{8}$ & 8.976 & 37.934 \\
\hline 1870 & 30.898 & 9.069 & 39.967 \\
\hline$I S 7 I$ & I +.626 & 6.307 & 20.933 \\
\hline 1872 & 26.208 & 10.829 & 37.037 \\
\hline 1873 & $48.3^{82}$ & 27.950 & 76.3 .32 \\
\hline $\mathrm{IS}_{74}$ & 40.674 & 27.603 & 68.277 \\
\hline 1875 & I $8.53^{2}$ & 23.534 & 42.066 \\
\hline 1876 & I 4.532 & 16.4 .33 & $30.9^{6} 5$ \\
\hline 1877 & I +675 & 21.650 & 36.325 \\
\hline 1878 & 23.624 & 19.334 & 42.958 \\
\hline I 879 & 32.717 & $22 .+35$ & 55.155 \\
\hline I 880 & $26.6+3$ & I 5.008 & $+1.65 I$ \\
\hline I SS $\mathrm{r}$ & $3 I+43 I$ & 16.053 & $47.45+$ \\
\hline I 882 & $+1.0+1$ & 10.462 & 51.503 \\
\hline$x S_{3}$ & 52.472 & 10.771 & 63.243 \\
\hline 1884 & +9.623 & 28.182 & 77.805 \\
\hline $1 S_{5}$ & 80.6 I & 28.104 & 108.722 \\
\hline \multirow[t]{2}{*}{1856} & 65.655 & $27.46 \mathrm{I}$ & 9.3 .116 \\
\hline & 761.023 & 337.300 & 1.09 .323 \\
\hline
\end{tabular}




\begin{tabular}{|c|c|c|c|}
\hline Years & $\begin{array}{l}\text { Countries } \\
\text { beyoud the sea }\end{array}$ & Montevideo & Total \\
\hline $\begin{array}{l}\text { I } 8 S 7 \\
\text { I } S S S \\
\text { I } 889 \\
\text { I } S 90 \\
\text { I } S 9 \text { I } \\
\text { I } 892 \\
\text { I } 893 \\
\text { I } 994 \\
\text { I } 895 \\
\text { I } 896 \\
\text { I } 897 \\
\text { I } 89 S \\
\text { I } 899 \\
\text { I } 900 \\
\text { I } 9002 \\
\text { I } 903\end{array}$ & $\begin{array}{rr}761023 \\
98.598 \\
\text { (a) } 130.271 \\
\text { (a) } 218.744 \\
\text { (a) } 77.815 \\
28.266 \\
39.973 \\
52.067 \\
5+.720 \\
61.226 \\
\text { I02.673 } \\
72.978 \\
67.130 \\
8+.442 \\
84.851 \\
90.127 \\
57.992 \\
75.227\end{array}$ & $\begin{array}{r}337.300 \\
21.94+ \\
25.361 \\
+2.165 \\
32.779 \\
23.831 \\
.33 .321 \\
32.353 \\
25.951 \\
19.762 \\
32.532 \\
32.165 \\
28.060 \\
26.641 \\
21.051 \\
35.824 \\
38.085 \\
37.4+4\end{array}$ & $\begin{array}{r}1.095 .323 \\
\text { I } 20.842 \\
155.632 \\
260.909 \\
\text { I I } 0.594 \\
52.097 \\
73.294 \\
84.420 \\
80.671 \\
80.958 \\
135.205 \\
105.143 \\
95.190 \\
111.083 \\
105.902 \\
125.951 \\
96.080 \\
112.671\end{array}$ \\
\hline & $2.158 .+23$ & $8+6.57^{2}$ & $3.00+.995$ \\
\hline
\end{tabular}

(a) - With assisted passages.

General Total (including first class passengers) 3.685.430. 
TRADES OF FOREIGN IMMIGRANTS,

IN THE LAS'T TEN YEARS, FROM I 894 TO I 903.

\begin{tabular}{|c|c|}
\hline 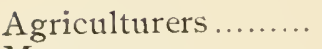 & \\
\hline Masons ... & 8.500 \\
\hline Upper cut & \\
\hline •. & \\
\hline hitects & \\
\hline tters. & \\
\hline rs .... & \\
\hline ers ........... & 1.33 \\
\hline men.. & \\
\hline$\ldots \ldots$ & \\
\hline ar & \\
\hline & \\
\hline male) & \\
\hline ..... & \\
\hline$\ldots \ldots$ & 30.99 \\
\hline ressmakers & 28.10 \\
\hline ... & 69 \\
\hline$\ldots$ & I 4 \\
\hline .... & $J$ \\
\hline lell ............. & \\
\hline n. & 0.75 \\
\hline ... & \\
\hline Dr & \\
\hline$\cdots$ & \\
\hline ....... & 1 \\
\hline ........ & \\
\hline n....... & \\
\hline ......... & \\
\hline ......... & \\
\hline rs $\ldots . .$. & 190 \\
\hline $\begin{array}{c}\mathrm{s} \\
\ldots \ldots \\
\ldots \ldots\end{array}$ & 113 \\
\hline $\begin{array}{l}\text { Eng } \\
\text { Glo }\end{array}$ & 7 \\
\hline .......... & 3.546 \\
\hline ....... & 54 \\
\hline & 3 \\
\hline$c$ & \\
\hline .... & I I 8.2 \\
\hline . ................. & \\
\hline & \\
\hline
\end{tabular}

Lithographers ...... 37

Marb!e-cutters ...... $\quad 59$

Sailors .............. $\quad 7.739$

Engine drivers ..... $\quad 445$

Mechanics............. 2.II3

Milliners ............. $6.05 \mathrm{I}$

Millers............... 605

Musicians ........... $\quad 796$

Miners.............. $\quad 1.272$

Physicians ........... 4I

Furniture makers... 92

Bakers ............... $\quad 2.382$

Stone cutters........ $\quad 1.208$

Painters .............. $\quad 926$

Laundresses .......... $\quad 8.749$

Fishermen........... I I 2

Teachers ............ I

Watchmakers....... $\quad 372$

Tailors............... 4.985 .

Without trade (children) ............. I I 3.433

Wilhout trade (women)............... 8.I I

Servants (male, fem.) 28.450

Hatters ................ 5O I

WVeavers (male, female) ............ 6.546

Typographers......... $4 \mathrm{~S}_{\mathrm{I}}$

Coopers ................ 316

Turners ............... 103

Dyers ................. 62

Harness makers..... 133

Viner, winemakers... $\quad 403$

Veterinaries .......... 33

Plasterers .............. $\quad 100$

Shoemakers .......... 6.094

Otlier trades ........ 8.430 


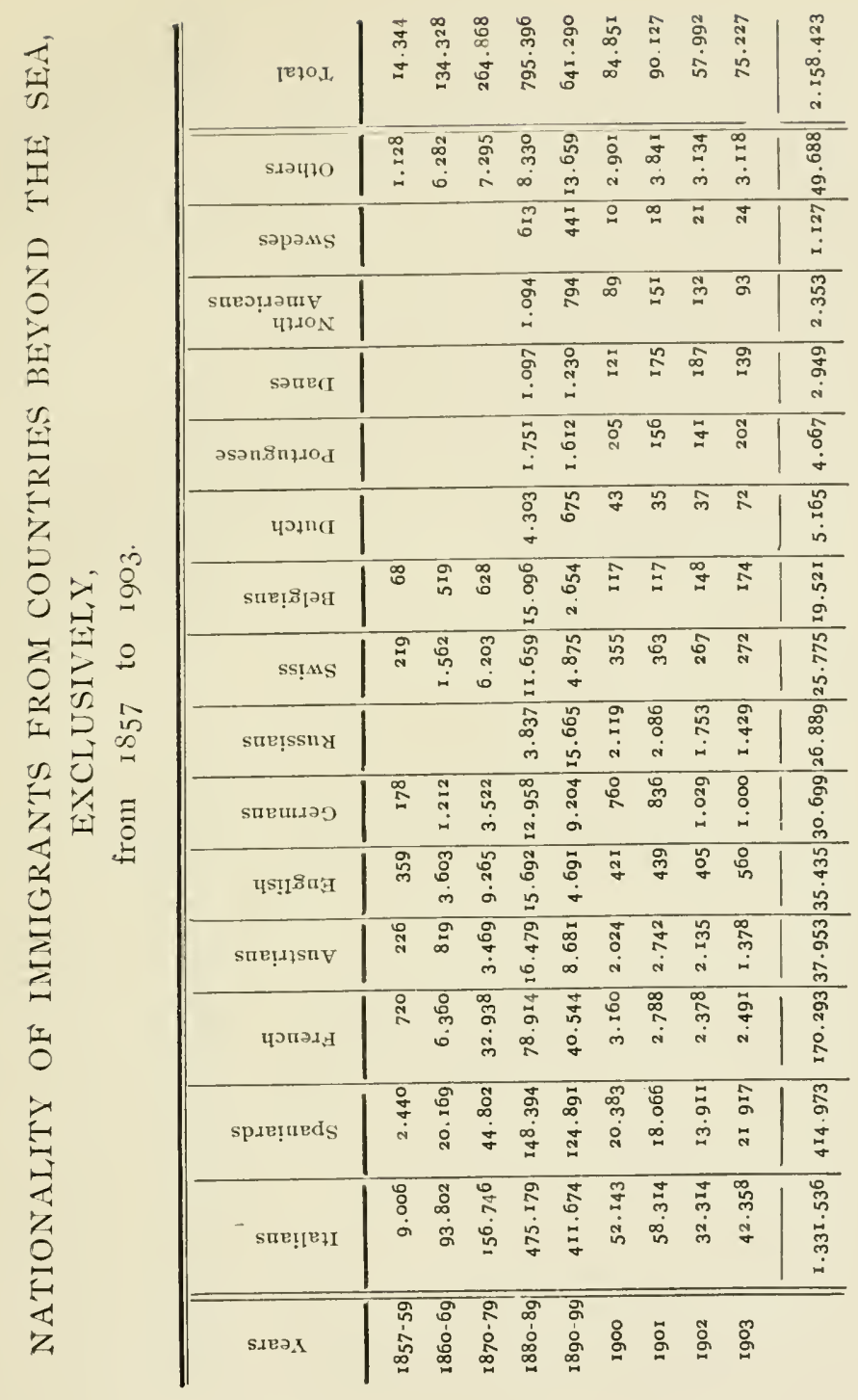





EXPOSITION DE SAINT-LOUIS

(ETATS-UNIS DE $N$. AMÉRIQLE)

\section{INDEX EXPLICATIF}

DES

\section{OBJETS EXPOSES}

PAR LE

\section{MINISI'ERE DES TRAVAUX PUBLIOS}

DE 1.1

RÉPUBLIQUE ARGENTINE
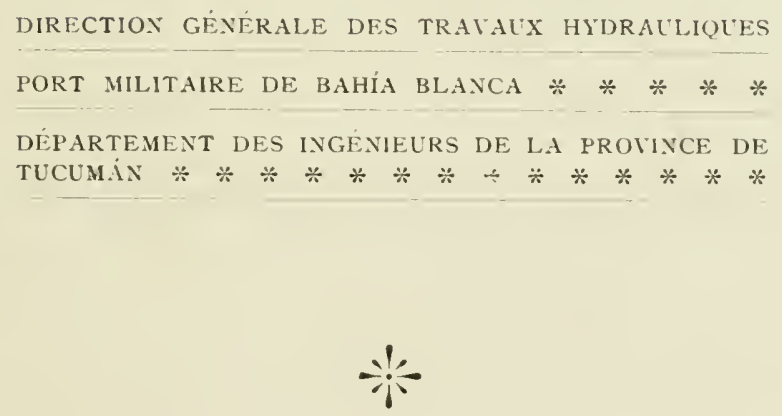

BUENOS AIRES

I57055-IMPRENTA, LITOGRAFIA Y ENCUADERNACIÓN DE JACOBO PEUSER

Calle San Martin 200, esquina Cangallo

1904 



\section{Avis au Lecteur}

Les objets exposés par le Ministère des Travaux Publies do la République Argentine et présentés par la Direction Direction Générale des Travaux Hydrauliques ent été classés en cinq groupes principaux:

I. - Río de la Plata.

II. - Río Paliaxí.

III. - Ríu Unuguir.

IV. - Port Militaire de Bahia Blanca.

T. Barrage de retence de la province de Tucumín. 



\section{I. - RÍO DE LA PLATA}

Ce grand plan, exécuté en relief. montre clairement tous les accidents du fond du Río de la Plita supérieur sur une étendue d'environ $3.500 \mathrm{~km} .^{2}$. On peut y étudier en déPlan- relief du

Supérieur. Echelle de $1: 40.000$ tail les nombreux canaux et bancs existants, ainsi que les nombreuses rivières qui forment le Delta du P'araná. La situation des signaux destinés il faciliter la navigation s'y trouve indiquée. Il comprend aussi les ports de Buenos Aires et La Plata, arec les camaux qui en permettent l'accès et leur balisage.

On a réuni en un album les six plans que nous allons décrire sommairement.

Atlas de plans
du Río de la Plata.

L’ne fois le relevé de la partie supérieure du Río de la Plata terminé, on a procédé à son balisage. Cette operation a constitué un de nos travaux les plus importants.

Les bouées indiquent nettenıent la route ì suivre afin d'éviter les échonements, avant si fréquents all grand préjudice du commerce en général. Les bouées lumineuses, dont la capacité est de j m. ${ }^{3}$, brûlent nuit et jour; la plupart soñt alimentées au gaz d'huiles minérales, les autres au gaz acétylène. le gav est transportó ì bord de bateaux balisenrs que l'en charge dans une usine spécialement construite dans ce but.

hans ce plan se trouvent condensés les résultats rles rele- Pa vés fitits par le personnel du Ministère des 'T'raviux l'ublics de la Nation jusqu'en 1908: il embrasse toute la partie sulan No 2.-Carte générale du Rio de la Plata. - Echelle de $1: 100.000$. générale du ba-
lisage lumineux
du Rio de la Pla-
ta. - Echelle de
I: 200.000 . (Année
1902). périenre du Río de la Plata.

Les relevés ont été faits arec une grande précision, moyennant de nombremx sondages et profils, ainsi que des ob- 
servations de marée soiquées. Une excellente triangulation s'étend sur toute la zone étudiée. Le plan contient en plus lindication de tous les signaux de narigation existants dans le fleure.

Plan No 3. - Côté Oriental du Rio de la Plata Supérieur.-Echelle. de $1:+0000$

Plan No t.- Rade de Buenos Aires. Echelle d e I: 100000. (Année 1703).

PJan No 5. - Pontón du Farallón. - F.chelle de I: +0.000 .

Plan No 6. - Nouveau Canal. -Echelle de 1: J0.000. (Année I903).

3. Modéle du bassin de carénage du Port de Bue nos Aires -
Echelle de I:ICO

4. Balisage d es canaux d'entrée au Port de But nos Aires.

5. Album photo. graphique:
Comme le problème de la navigation intérieure du Paraná et de l'Uruguay dépend de la viabilité des canaux du côté Oriental du Río de la Plata. on a établi un plan ì l'échelle de 1:40.000 permettant d'étudier parfaitement ces canaux dans tous leurs détails.

Ce plan comprend la zone du Río de la Plata s'étendant tout au long de la ville de Buenos tires: il donne la situation du Port et de ses canaux d’accès, avec leur balisage.

Ce plan comprend, avec tous les clétails, la zone de moindre profondenr de la route de navigation de plus grand calage du Río de la Plata, avec l'indication de son balisage et de la position de tout les rochers pouvant offrir quelque danger an navigateur ì l'approche du Farallón.

Ce canal fut balisé pour la première fois en 1892; depuis, le passage des bateaux et l'action du courant ont produit un approfondissement naturel de plus de 3 pieds. Il a aujourd'hni une profondeur de 19 pieds en basses eaux, et les bouées lumineuses qui le bordent en ficilitent considérablement la navigation.

Le port de Buenos Aires a deux bassins de carénage. Ce modele représente le plus grand, dans tous ses détails. On y peut voir le dispositif d'épuisement. l'installation des machines faisant fonctionner les pompes, ainsi que tous leurs détails de construction.

Ce plan indique dans tous les détails, la situation des signaux et bourées (lumineuses ou non) qui démarquent le passage de navires dans leur entrée an port de Buenos . Aires, ainsi que colle du Sémaphore, et en fin les différents types de signaux les plus généralement adoptés pour lo balisage.

On a remi dans ret album le's photographies de diffórents types de dragues adoptés diuns le pays, ainsi que des remorquen's et alutres embarcations appartenant an service du Ministire. Il contient encore quelques vues concernant d'importants travanx exéchtes ou en cours d'exícution, 
suffisants par enx-mêmes pour donner une idée de l'état davancement et de progrès des travaux publics dans la hépublique Argentine. Nous arons ajouté à la fin de la brochure un index du contenu de l’Album.

Celui-ci est le dernier des plans exécutés par la Direction 6. Plan du Port Générale des Travaux l’ublies. On pent y voir la disposition générale dı port et de ses camaux d'entrée, le port du Riachuelo, le Dock sud, etc. Sur les deux rives du Riachuelo se trouvent d'excellents quais en bois permettant l'amarrage des bateaux, notamment de ceux de cabotage. sur la rive nord il y a actuellenent en construction $1.200 \mathrm{~m}$. de nouveaux quais.

A lentrée du Canal Sud se trouvent les Ateliers du Ministère des Travaux Publics affectés ì la réparation des trains de dragage, et en g'énéral de toutes ses embarcations. Dans la Darse Nord sont installés les Iteliers et les Bassins de carénage du Ministère de la Marine.

Pour donner une idée plus exacte de limportance du port, i. Panoramas du on a ajouté trois panoramas du même, pris de différents Port de Buenos points de vue, et domnant une vue d'ensemble du mouvement des narires d'outre-mer et des petites embarcations.

On a réuni en un album les photographies des embarca- 8. Album phototions destinées á tous les services du ministère. Nous arons graphique des ajouté ì la fin de la brochure une liste des vues contenues dans l'. 116 mm.

\section{II. - RÍO PARANÁ}

L'importance des études réalisées ì l’occasion dı Concours I. Plan-relief du pour la construction du port sur la partie de ce fleure vis-ilvis la ville du Rosario, explique suffisamment la raison Rio Paraná en face de Rosario. - Echelle de d'être de ce plan.

On y a represcuté, de mètre en mìtre, les courbes de niveau du fond du fleuve, de façon ì faire ressortir la forme générale du lit et tout ses aceidents, tels que banes, camaux, ete.

Ce plan aỹant été dressé, comme le précédent, dans le 2. Plan-relief du but de compléter les cartes relevíes pour servir de base $\begin{gathered}\text { Ro } \\ \text { face de daá en } \\ \text { faná. }\end{gathered}$ à l'étude du port de la ville de Paraná, on l’il exécuté - Echelle de 
suivant le même système adopté pour le plan antérieur, en marquant de mètre en mètre les courbes de niveau. Il comprend toute la zone étudiée en vue du choix du meilleur emplacement rlu port projeté.

Tout le cours du Río Paraná, depuis Corrientes jusqu' à son embouchure, a été divisé en trois sections, nommées respectivement: Paraná Supérieur, Paraná Moyen et Paraná Inférieur. La première comprend la partie dı fleuve qui va de Corrientes à Santa Fe: la deuxième celle qui va de Santa Fe à Rosario; et enfin la troisième celle qui va de Rosario à l'embouchure du Guazú. Le pareours de ces différentes sections est d'environ 580, 160 et $420 \mathrm{~km}$.

Le dossier en question comprend une carte (en 16 feuilles, à l'échelle de 1: 20.000$)$ de la Section Rosario - Río de la Plata. Une feuille Index (it l'échelle de 1:100.000) indique la position relative des feuilles contenant le relevé total.

Ce relevé s'appuie sur une triangulation embrassant les deux rives, et dont les sommets devaient offrir les points de repère nécessaires pour établir les profils de sondages. Ceuxci ont été pris ì des distances variant depuis un maximum de $200 \mathrm{~m}$. (aux points de plus grande profondeur et de navigation plus aisée) jusqu' ì un minimum qui atteint $20 \mathrm{~m}$. (aux passes peu profondes). Les sondages de chaque profil sont très nombreux et d'autant plus rapprochés que les points sont plus intéressants; la position de chaque sondage est d’ailleurs rapportée ì des signaux situés sur la terre ferme. Deux marégraphes, à Rosario et ì San Pedro, et dix échelles fluvionétriques établies tout au long du fleuve et constamment observées pendant l'exécution des opérations, ont fourni les éléments nécessaires ì la réduction des hautenrs observées au zéro hydraulique. Hormis ces échelles fixes, on a toujours établi aux endroits les plus importants, tels que les passes des échelles provisoires qui ont rité observées pendant toute la période d'études.

Les plans contenus dans le dossier ont été exécutés sur ces dounées. Le fond du flenve se trouve représenté au moyen de courbes de nivean équidistantes de $1 \mathrm{~m}$. Sous forme d'annexe, nous ajoutons une liste détaillint tous les plans constituint le dossier. 
Ce dossier rontient, outre une fonille lndex ì l'áchelle de $1: 100.000$, 8 fenilles a l'échelle de $1: 100.000$ embrasDossier de plans du Paraná $\mathrm{Mo}$ sant le cours du fleuve Paraná depuis Rosario jusqu'à Sinta Fe, sur une étendue de $160 \mathrm{knt}$. Ces plans ont été exécutés exactenent sur le modèle de cenx du Paraná Inférieur déjà décrits. On a détaillé sous forme d’aimexe, tous les plans constituant le dossier.

On a ajouté dans cette planche les données concernant la construction des ouvrages projetés pour doter d'un port Carte murale du la ville de Rosario et dejá en cours d'exécution. Le ecentre de la feuille contient une planimétrie détaillée montrant la rue d'ensemble des travaux de correction, de dragage et autres projetés; et tout autour on a disposé artistement des vues et des coupes des ouvrages les plus importants, tels que les quais en maçonnerie ou en bois, les jetées en béton, ainsi que les diflerents types d'embarcation pour le dragage et le service du port.

Cet albam fait connâitre les points les plus importants du fleuve, ainsi que les traviux quon $y$ a éxecutés. Un Index tétaillé de toute les rues se trouve à la fin de la brochure.

\section{III. - RIO URUGUAY}

Le port de Concepción del Lruguay, situé à $18+\mathrm{km}$. de I. Plan-relier du l'embouchure de ce fleuve dans la I'lata, est le dernier que puisse atteindre la navigation d'outre-mer. 11 posséde Port de Concep-
ción d $: \cdot 1$ U u guay. . Echelle de $I: 1.500$ un grand môle approprié ì cette navigation, situé sur le bras principal du fleuve, et de un bassin de cabotago emplacé sur un bras secondaire, que l'on atteint par un canal d'aceìs dont l'entrée est défendue par un brise-lame en pierre.

Le plan signale tontes (es installations, ainsi que les accoidents dufoud du fleuve dans ce parage.

Là même se trouvent les bureaux de la C'ommission des Etudes et Travaux du Río Lruguay, dépendant de la Direction fićnérale des Travaux Hydrauliques. 
2. Dossier de plans du Río Uruguay.

Les 21 plans qui composent ee dossier contiennent : une reconnaissance du l'Uruguay Supérieur (depuis Concordia jusqu'à Santo Tomé ); un relevé de l'Uruguay Moyen ( de Concordia ì Concepción) et un autre de l'Uruguay Inférieur.

Ces plans généraux sont complétés par d'autres de détails,-concernant les passes difficiles pour la navigation, établis à l'échelle de 1:10.000 et incliquant les améliorations et balisages projetés ou en cours d'exécution.

Une liste détaillée de ces plans a été ajoutée en annexe à la fin de la brochure.

3. Dossier de plans des études du Rio Uruguay.

t. Mémoire descriptif.

5. Album photo-

Ce dossier comprend 15 planches contenant les données hydrauliques les plus importantes concernant le Río Uruguay, telles que des profils instantanés, des études de marée et de pentes, des tableaux graphiques avecles observations hydrométriques, des études de débits et de vitesses à différents endroits, etc.

En annexe, nous ajoutons un détail de tous ces plans.

A fin de compléter les renseignements concernant les études et les travaux du Río Uruguay, nous avons rédigé un mémoire descriptif exposant sommairement toutes les études ou projets entrepris en vue d'améliorer la navigation de ce fleuve.

Cet album, comme tous les autres, contient des vues de parages, de travaux, d'éléments de transport, de signaux de balisage, etc. Un détail de ses différentes planches a été ajouté en annexe.

\section{IV.-PORT MILITAIRE DE BAHÍA BLANCA}

1. Plan de l'estuaire de Bahia Blanca.
Ce plan montre la topographie et l'hydrographie de l'estuaire de Babía Blanea, ainsi que l'emplacement du Port Militaire (a Punta Alta), du Port Commercial du chemin de fer dus. (près de l'Arroyo Napostá), et enfin celui du Port Commercial du chemin de fer de B. B. et N. O. (sur l'Arroyo Galvín). Plus à l'intérieur de l'estuaire, il y a encore un môle destiné au frigorifique de C'uatreros. 
Le plan fait roir. par des teintes blenes qui angmentent d'intensité avec la profondeur de l'eau, que dans l'estuaire il n'y a pas moins de 32 pieds de profondeur en basses eaux I de l'Atlantique à Punta Alta, où se trouve le P'ort Militaire): il montre aussi que le mouillage de Puerto Belgrano (en face du Port Militaire) pent abriter la flotte la plus grande. In mouillage part un camal d'environ $20.000 \mathrm{~m}$. draguć jusqu'ì 21 p. en basses eanx et 3:2 p. en hautes eaux, qui permet aux bateaux d'entrer dans la darse du Port Militaire. L'n autre canal dragué à 18 p. en basses eaux et 29 p. en hautes eaux, permet aux bateaux marchands d'avancer jusqu'au Port Commercial du chemin de fer du S.

Ce plan comprend tous les ouvrages projetés en vue d'un futur lointain, ainsi que ceux actuellement en construction. qui suffisent amplement pour parer aux exigences de la marine nationale.

Ces ourrages. pour la plupart déji achevés, comportent un avant-port devant mettre à l'abri l'entrée ì la darse de marée où se trouvent amarrés les cuirassés et ayant $30 \mathrm{p}$. d'eall en basses eaux et $41 \mathrm{p}$. en hautes eaux ordinaires. De la darse de marée, les bateaux passent an grand bassin de carénage (le plus raste dans toute l'Amérique et pourant loger n'importe lequel des plus grands navires i flot actuellement, soit de guerre soit marchand): ou bien ils accostent contre le quai destiné all transbordement de l'armement, quai pourru de grues hydrauliques. une d'elles de $30 \mathrm{t}$. de puissance. Ce quai est le seul ourrage non encore acheré: mais on compte le terminer le milieu de l'année courante $(1904)$.

Tout autour de la darse de marée, du bassin de carénagge et du quai de transbordement, se trouvent les ateliers, le dépôt d'armements, les maisons pour employés, une promière section de l'Hôpital Taval déjì en état de loger 80 malades en conditions normales et 400 en cals de guerre: il y a aussi un service complet d'eaux courantes et d'écouts. l'éclairage électrique, le service des postes et télégraphes. En fin, on a formé une population florissante d'cuviron 1.500 îmes. Lì même où en septembre 1898 il n'y arait qu'un réritable désert. 

Carénage et de la darse attenante. Echelle de 1:2.000.

Profils nombreux des ouvrages les plus im. rtants.-Eche lle de I: ico

Disposition gूénérale de la jetée d'accostement - Echelle de $1: 200$
Ce plan contient les détails principaux du bassin de citrénage: largeur, 2.2. m.; largeur, $27 \mathrm{~m}$. à l'entrée; profondeur, $10 \mathrm{~m}$. sur le seuil en moyennes hautes eaux ordinaires. - Le plan indique le système de construction du bassin de carénage, entièrement construit en béton de ciment Portland, sable et caillou. Un revêtement en granit sur les parois vues lui donne l'aspect extérieur d'une con struction entièrement en granit.

Le bassin pent se vider en 2 heures et demie, au moyen de deux grandes pompes centrifuges de $400 \mathrm{HP}$. chacune, et il est pourvu de g'rues hydrauliques, éclairage électrique, conduites d'eanx courantes, etc. Il est fermé par une porte glissante pouvant s'ouvrir ou se fermor hydrau liquement en 3 minutes. Il a en outre deux portes flottantes pour les clôtures intermédiaires.

Ce plan contient les données principales concernant les ouvrages principaux, ci-après indiqués:

a) Canal d'entrée de $80 \mathrm{~m}$. de large au fond avec une profondeur d'eau de $32 \mathrm{p}$. en hautes eaux ordinaires et 21 p. en basses eaux.

b) Edifice des pompes, et portes du bassin.

c) Diagramme comparatif des plus grands navires relativement au bassin de carénage.

(l) Système de construction du bassin de carénage, et vue des travaux à différentes périodes.

e) Détails de la porte glissante fermant l'entrée du bassin de carénage.

Ce plan indique la situation du quai d'accostement par rapport au bassin de carénige, ainsi que le type normal du quai et les dispositifs adoptés pour les différentes parties ci-après indiquées :

и) Grues hydrauliques roulantes ì portail, avec grands dépôts dans la section réservée au transbordement d'armements et de matériaux divers.

b) Grue hydrutique fixe avec bras derricling, pouvant remuer jusqu'it 30 t. et avec voie forrée de sorvice pouvant transporter de grands canons ou des poids roonsidérłables. 
c) Elévateurs pour la décharge du charbon aux dépôts sur terre ou pour le charger ì bord, soit sur chalands soit sur wagons, après triage et pesige préalables.

Ces deux albums contiennent une collection des plans les plus inportants concernant la Station Navale, les Phares, les Sémaphores et autres installations. Elle comprend 120 planches de $0 \mathrm{~m} .65 \times 1 \mathrm{~m} .20$. On y voit des plans généraux, différentes études, le canal d'entrée, le bassin de carénage, l'édifice des machines et méeanique, les portes glissantes; les eonduits hydrauliques; des grues; la darse de marée, la jetée d'aceostement; la direction des eaux courantes, ainsi que leur dépôt et Station; les égouts; et enfin, divers edifices et projets.

Tous ces plans sont d'ailleurs détaillés dans l'annexe qui complète la brochure.

Cet album contient 62 vues de l'ensemble des travaux du 8. Album photoPort Militaire; elles font voir l'état des travaux et permettent graphique. de juger des services qu'ils rendent ì la marine de guerre. Ces vues sont détaillées une à une dans l'annexe déji mentionné.

\section{V. - BARRAGE DE RETENUE de la Province de Tucumán}

Le Département des Travanx Publies et Irrigation de la Province de Tucumán a projeté un gran barrage de retenue d'une capacité de près de $200.000 .000 \mathrm{~m}^{3}$., destiné à l'irriga1. Modéle en relief du barrage de Cadillal. tion de cette riche province. Le coût de cet ouvrag'e a été estimé à plus de $1.000 .000 \$ \mathrm{~m} / \mathrm{n}$. Le plan indique la disposition générale de l'ouvr'igee, ainsi que l'étendue du bassin de retenue.

L'anteur du projet est M. l'ingénien' Carlos Wauters, Directeur del Département de la province de T'ueumán.

Ce plan indique à une plus grande íchelle, l'ensemble des 2. Modè de r'enouvrages projotés pour la retenue et la déchiarge des ge de Cadillal. eatix. 



\title{
A N N E X E
}

\section{Index des Plans et Photographies contenues dans les différents dossiers et albums}

\author{
Annexe I. - RIO DE LA PLATA \\ 1。. - Album photographique de plans (I)
}

1. Vue générale des Ateliers du Ministère des T. P. (avril 1899).

உ. Vue générale des Ateliers du Ministère des T. P. ioctobre 1903).

3. Vue générale, y compris le Canal d'entrée (1903).

$4 .>\gg$ prise d'un signal du Canal Sud (1902).

5. 》 》 (décembre 1902).

6. Cale de radoub du Ministère (juillet 1899).

$7 . \gg \gg>\quad$ (janvier 1900 ).

8. > > $>$ (2) vues) (1900).

9. Ateliers et Jetée de défense du Canal Sud d'entrée.

$10 . ~ \gg$ du Ministère; chalet de la Direction (décembre 1902).

11. Vue en auvre des Ateliers primitifs (1897).

12. Moteur Compound de l'Atelier (juillet 1899).

13. Atelier d’ajnstage (juillet 1908).

$14 . \gg \gg(\gg)$

15. Petit Tour (1898).

16. Dynamo (septembre 1903).

17. Gran Moteur.

18. Petit 》

19. Atelier de Menuiserie (antêt 1903).

20. $>$ > (décembre 1902).

(I) Toutes ces rues photographiques se rapportent au Port de Buenos dires. 
21. Seie sans fin construite dans les Ateliers (décembre $1901)$.

2.). Poinconneuse et rabatteuse.

93. Grand Tour (1900).

24. Petit Martinet ì vapeur (1900).

25. Forge (1903).

26. Chaudronnerie (1902).

27. $\gg(1903)$.

28. $\gg$ Forge (1902).

29. Fonderie (1902).

$30 . \quad$ (1909).

31. Usine à gaz et Bouées prêtes à être chargées (Façade Nor'd).

32. Usine ì gaz (Façade Sud).

33. 》 》 Accumulateurs, dépôt d'eau et gazomètre.

34. Bouées lumineuses.

35. Usine à gaz. Môle et treuils pour la manouvre des bouées.

36. Bouées luminenses.

:77. Usine à graz. Moteurs compresseurs.

38. 》 》 Chaudière.

39. 》 》 Dépurateurs.

$40 . \gg \gg$ Fours.

41. Dépôt d'eau et Filtre.

4.). Sémaphore et Habitations du second Chef.

43. Refouleur.

44. Terrains du port, pendant leur remplissage.

t5. Matériel de remplissage arrivant sur place.

46. Terrains du port après le remplissage.

47. Entrée du Canal sud.-Jetée de défense.

$48 . \gg \geqslant$

59. I Vue de la Jetée de délense.

51. Jetée de l'entrće du port.

5.2. I Reconstruction des quais du Riachuelo.

54.

et vue du Port du Riachuolo.

55.

sti. Port du Riachuelo.

57 . 


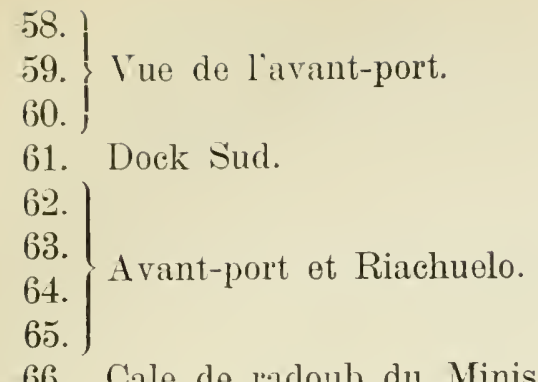

66. Cale de radoub du Ministère.

67. I Bassin $n^{\circ} 3$.

70. j Elévateurs de grains.

71. Service Hydrographique du Ministère de la M. ( Darse Nord ).

72. Bassin de carénage.

73. Pont du Riachuelo.

74. Edifice des Machines.

75 . Embarcations en réparation.

77. Vues à vol dooiseau des Travaux du port de la Capitale.

78. Jetée extérieure au Dock Sud.

79. Entrée aux Jetées de La Plata.

80. Dock Central (La Plata).

81. 》 》 》

82. Station Navale (Río Santiago, La Plata).

\section{2.. - Album photographique d'Embarcations}

1. Chaland pour le transport de matériaux.

2. Martinet à vapeur flottant.

3. Grue flottante et chaland pour transport de matériaux de dragage.

4. Martinet flottant et chaland pour matériel de dragage.

5. Chalands pour transport de matéril dragué.

6.

7. Chalands ave chabitations, pour le personnel des études. . 
9. Chaland avec habitation et Ponton Sémaphore.

10. Ponton Sémaphore.

11. $\gg$ et chaloupe pour les études.

12.

13.

14.

15. Chaloupes pour les études.

16.

17.

18.

19. Chaloupe et vapeur pour les études.

20.

21. Vapeur pour les études.

22.

23. Vapeur pour inspection et balisage.

24.

25.

26.

27. Remorqueurs.

08

29.

30. Chalands pour matériel dragué.

32. Chaland avec habitation pour les études.

33. 34 Chaland pour matériel dragué.

35.

36.

37.

38.

39

40.

41. Dragues.

42.

$+3$.

4.4.

45.

46.

47.

48. Drague et Refouleur. 
49. Excavateur et Refouleur.

50. Chaland perforateur et ehaland-pompe.

51. Grue flottante et Refouleur.

52. Drague.

\section{Annexe II. - RÍO PARANÁ}

\section{0.- Dossier de plans}

\section{Paraná Inférieur}

Feuille-Index: De Rosario à l'embouchure du Guazú.

1. Ville de Rosario et environs.

2. Passes Alvear et Paraguayo.

3. Villa Constitución et environs.

4. San Nicolás et environs.

5. Passes du Tonelero et de Las Hermanas.

6. Obligado et environs.

7. San Pedro et environs.

8. De San Pedro à Isla Grande.

9. Embouchure du Paraná de Las Palmas et environs.

10. Ile du Bizcaíno, Río Ibicuy, Zanja Mercadal et embouchure supérieure du Talavera.

11. Ile La Botija et embouchure inférieure du Talavera.

12. De l'ile du Dorado au Ceibo.

13. Passe du Portugués et environs.

14. Río Bravo et son embouchure.

15. Embouchure du Guazú et du Bravo.

\section{Paraná Moten}

1. Ville de Paraná et environs.

2. Ville de Santa Fe, Riaeho et partie du Paraná jusqu au Tragadero.

3. De Paso del Paracao aux îles de la Araña.

4. Des îles de la Araña à Taeuaní.

5. De Tacuaní ì los Reyes.

6. De l'embouchure de Los Reyes à l'île Los P'ájaros.

7. De l'île Los Pájaros à l'embouchure du Bobo.

8. De San Martín à Alberdi. 


\section{0. - Album photographique}

1. Puerto de Zárate.

2. Rosario. Vue de la ville et des môles nationaux.

3. I Rosario. Mouillage.

5. Train de dragage de la passe Paracao.

6. Spar buoys de la passe de la Paciencia. Bouées et balises d'alignement de la passe de Paracao.

7. Bajada Grande. Vue geénérale et môle.

8. Paraná. Salto del Calderón.

9. Paraná. Mouillage.

10. Paraná. Tieux port.

11. Paraná. Panorama depuis le Morro.

12. Paraná. Four à chaux et panorama.

13. Santa Fe. Vues de la ville et du môle.

14. Santa Fe. Installations de la Commision des Etudes, et coupe du Paraguayo.

15. Colastiné. P’ort et dépôt de bois en grume.

16. Colastiné. Vues du port.

17. Embouchure de la Piragua et établissement de Santa Elena.

18. La Paz (Tannerie). Tue de Esquina.

19. Tues de Esquina.

20. Port Reconquista. Môle de Goya.

21. Bella Vista.

2.. San Antonio Pilconayo.

23. Port de l'Assomption (République du Paraguay).

24. Mouillage et môle de Corrientes.

25. Corrientes. Vues du môlo et su Palais de Gouvernement.

-26. Corrientes. V'ues de la ville.

27. Ilot de pierre, ì l'aval de Itatí.

-8. V'ues de ltatí.

29. Eglise de Itatí. Groupe d'indieus «Palmas».

30. Vues de Humaití et envirous.

31. Humaitá.

32. Villa Pilar. Ile du Aquino.

33. Vues de Formosa.

34. Villa Franca. Śous-préfecture de Formosa. 
35. Vues de Formosa.

37. Guardia Angostura, près Villeta. Villeta.

38. Cerro Lambaré. Empedrado.

39. Colonie Urquiza. La Curtiembre.

40. Zanja Mercadal.

\section{Annexe III.-RÍO URUGUAY \\ 10. - Dossier de plans.}

1. Reconnaissance de l'Uruguay Supérieur depuis Concordia jusqu'à Santa Tomé.

2, 3, 4. Plans généraux du cour's moyen du fleuve, avec la configuration générale du lit et la position relative des points principaux.

5, 6, 7. Plans du cours inférieur du fleuve, montrant une topographie tout-à-fait différente des autres parties.

$A, A$. Plans de détail des passes du Corralito et du Yuquerí, situés immédiatement à l'aval du port de Concordia. (La première de ces passes est semée de bas-fonds de pierre).

$B$. Plan du coude Dayman. (Partie du fleuve fort régulière, de navigation aisée).

$C, C$. Passe de Hervidero. (Canal tortueux entre des bas-fonds de pierre, dont on projette la rectification ì une profondeur minima de 9 pieds).

D. Passe de Chapicuy. (C'est la passe la plus difficile qui entrave l'accès à Concordia; elle a donné lieu à des études sérieuses et à des projets de canalisation bien étudiés).

$E, F, G, H$ et $I$. Plans des passes de Guaviyú, Sombrerito, San José, Cancha Seca et Pepe Ají, avec fonds de sable et gravier.

$J$. Passe de Peruchoverne. (C'est la dernière des passes difficiles pour la navigation entre Concordia et Colón).

K. Passe de San Francisco. ( Elle a été canalisée sur une 
largeur de $100 \mathrm{~m}$. jusqu'aux 9 pieds de profondeur minima, en vue de faciliter l'accès au port de Colón). L. Plan du port de Paysandú, sur territoire de la Republique Orïentale. (C'est un bon port avec de grandes profondeurs, dont l'aecès se trouve entravé par la passe Almiron, située $7 \mathrm{~km}$. en l'aval).

11. Passe de Almiron. (Elle a une profondeur minima de

10 pieds et son amélioration reste à charge de la République Orientale de l'Uruguay.

N. Plan de la rade et port de Concepeción del Uruguay.

\section{2.. - Dossier de plans concernant les études.}

1. Profils instantanés de l'onde de marée, montrant la forme que prend la nappe d'eau du Río Uruguay sous l'influence des marées de l'Océan Atlántique se transmettant depuis $293 \mathrm{~km}$. de l'embouchure du fleuve pendant basses eaux.

2. Ciraphique de l'onde de marée montrant la forme de l'onde pour une marée ordinaire et pour une extraordinaire.

3. Profil en long de la nappe d'eau du Río Uruguay à liaval de Concordia, indiquant les pentes que prend la nappe d'eau du flenve à differentes périodes.

4. Graphique arec la référence des zéros des échelles hydrométriques, nivelés par l'étude des marées, faute d'un nivellement terrestre (en voie d'exécution).

5, 9. Graphique des observations hydrométriques enregistrées à Nueva Palmira, Fray-Bentos, Concepción del Uruguay, Nueva Escocia, Concordia et Paso de los Libres.

10, 11. Iiagrammes des vents et pluies enregistrées pendant les années 1900 et 1901 à Concepción del Uruguay.

12, 13. I)iagramme représentant la rariation du débit et des vitessos pour différentes périodes du fleuve aux stations de Concepción del Uruguay et de Nueval Escocia, ainsi que la correspondance des dilférentes hauteurs d'eau entre Concepción del Lruguay et Concordia. 
14, 15. Profils des vitesses aux stations de Concepción del Uruguay et Nueva Escocia, pour différentes hauteurs d'eau et conditions de courant.

\section{3.. - Album photographique}

1, 2. Types de balises indiquant l'axe du canal dragué aux passes de Banco Grande et Altos y Bajos. (Allumées pendant la nuit et portant une échelle donnant directement la profondeur minima du canal dragué.)

3, 4. Vues du môle d'outremer à Concepción del Uruguay, pendant une porte crûe dı fleuve.

5. Môle de Concepción del Uruguay, vu du côté d'amont.

6, 7 et 8. Navires en déchargè au môle de Concepción.

9. Accès au môle de Concepción du côté de terre, avec la vue des barraques du fluviographe (à droite) et du garde (à gauche).

10. Ir. pendant une forte crîe.

11, 12. Pont donnant accès au môle, pendant une forte crûe.

13. Partie supérieure du pont donnant accès au môle, et édifices fiscaux.

14. Entrée du canal d'accès au Port intérieur de cabotage de Concepción del Uruguay.

15, 16. Vue de ce canal d'accês.

17, 18. Dragues pour l'ecavation du canal d'accès.

19, 20. Dragues travaillant dans le port intérieur de cabotage de Concepción del Uruguay.

21, 22. Cale de radoub du Ministère (même port).

23,24 . Travaux d'amélioration et agrandissement de la cale ${ }^{*}$ de radoub (même port).

25. Drague travaillant dans le Río Uruguay.

26. Campement d'ingénieurs, pendant des études.

27. Bureaux de la Commission des Etudes et Travaux du Río Uruguay à Concepción del Uruguay.

28. Ateliers du Ministère (même port).

29. Vue du port actuel de Colón.

30. Vue du port actuel de Concordia.

31. Autre vue de Concordia, pendant les hautes eaux.

32. Vue d'un des nombreux rapides du Río Uruguay. 
Anexe IV. - PORT MILITAIRE DE BAHIA BLANCA

\author{
$1^{\circ}$.- Dossier de plans. \\ Plans gínéraux et Etudues diverses
}

1. Plan général des travanx maritimes pour la défense des côtes atlantiques de la République Argentine (Echelle de 1:2.500.000).

2. Plan hydrographique de Puerto Belgrano à Bahía Blanca (Plan général des travaux, à l'échelle de $1: 150.000)$.

3. Plan. Sondiages. (Echelle de 1:40.000).

4. 》 Puits et perforations. (Echelle de 1: 40.000).

5. 》 Id.

6. » Plan Topographique, hydrographique, geognostique et liydrognostique des environs de Punta Alta ì Puerto Belgrano (Échelle de 1:5.000).

7. P'rofils en travers strivant $\mathrm{AB}^{\prime}$ de la planche antérieure.

8. Id. suivant $A B^{\prime}$ id. id.

9. Id. 》 $\mathrm{C} \mathrm{C}^{\prime}$ id. id.

10. Id. en long suivant XY id. id.

11. Id. id. id. snivant $\mathrm{WZ}$ id. id.

12. Études hydrognostiques autour de Puerto Belgrano (sections).

13. Eléments d'étude du canal d'entrée.

14. I'lan de l'Arsenal de la Marine, réduit aux travaux nécessaires pour le futur port. (Echelle dle $1: 2.500$ ).

15. Plan de la Station Navale devant se transformer un jour en Arsenal de la Marine. Travaux les plus urgents. ( Eelielle de 1:2.500).

16. Plan général de construction de la Station Navale (Echelle de $1: 2.500$ )

17. Plan général de la station Navale (Echelle de 1:2.000). 
Canal d'entriée

18. Plan général des sondages du canal d'entrée et alvintport. (Echelle de 1:2.000).

19. Bouées diverses de signalement et d'amarrage.

20. Trépied de balisage.

\section{Bassin de Caliénage}

21. Bassin de carénage. Plan et sections. (Echelle de 1:200). 22. \ disposition des eouches de béton dans le plafond et les murs latéraux. (Echelle de 1:50).

\section{EDIFice des Machines}

23. Vue vers l'avant-port. (Eehelle de 1:50).

24. Côté et façade du compartiment des chandières. (Echelle de 1:50).

25. Plan et sections normales des mur's de quai. (Eclielle de 1:50).

26. Plan de l'installation des pompes centrifuges. (Echelle de $1: 100)$.

27. Détail de l'installation des pompes des infiltrations. (Echelle de 1:20).

28. Détail des moteur des pompes centrifuges. (Echelle de $1: 10$ ).

29. Détail des pompes centrifuges. (Echelle de 1: 10).

30. Détails des portes de la conduite d'écoulement. (Echelle de $1: 10$ ).

31. Détail des chandières. (Echelle de 1:10).

32. Tour pour accumulateur hydraulique. (Echelle de 1:10).

33. Dispositif d'ensemble de la machinerie hydraulique et de l'aceumulateur. (Echelle de 1 : 20).

34. Détails du moteur hydrodinamique.

35. Détails de l'aecumulateur hydraulique.

36. Porte glissante avec pont-levis et à mouvement hydraulique, avee diagramme (Dessin de projet).

37. Porte glissante. -- Plan, vue et section (Dessin d'exécution).

38. Id. Coupe en long et sections diverses (Id.) 
39. Id. Machinerie hydraulique de manoeurre (Id.)

40. Porte flottante (Dessin de projet).

41. Id. Vue longitudinale et transversale (Dessin d'exécution).

42. Id. Sections id. id. (Id.)

43. Id. Plans variés (Id.)

\section{Condute hydralligue, Grues, etc.}

44. Dispositif d'ensemble des grues, de la conduite hydraulique, voies ferrées, etc., relativement au mur d'accostement. (Echelle de 1:20).

45. Plan général des conduites de pression, de retour, et des eaux courantes relativement au bassin de carénage. (Echelle de 1:200).

46. Grue fixe de 30 tomnes.

47. Grue roulante de 5 tonnes.

48. Girue roulante de $1 \frac{1}{2}$ tonnes.

49. Treuil hydraulique de 5 á 10 tonnes.

50. Id. id. de 1 tonne.

\section{DARSE DE MARÉE}

51. Etat du dragage le 31 août 1903. (Echelle de 1:1.000).

52. Coupe et talus ouest du bassin à flot.

53. Détails des talus, échelles, poteaux d'amarrages, bouées, ete.

\section{QuAI D'ACCOSTEMENT}

54. Construction d'un cofferdam pour mettre à sec la zone destinée aul mur d'accostement.

5.). Plans, vues et sections.

56. P'ierre de taille, poteaux d'amarrage, anneaux pour gaffes, retc.

57. Conduites, poteaux, bittes et autres accesoires métalliques.

58. Suction normale et coupos diverses du quai d'accostement.

54. Puits de descente au tunnel des conduites. 


\section{$-\underline{9}-$}

60. Conduites de décharge des égouts.

61. Dispositif du mur d'aceostement, avec grues, et élévateurs de charbon.

Dérivation des faux courantes au Río Saute Grixile

62. Plan cadastral de Bahía Blanea.

63. Id. Topographie générale et profils en long. (Echelle de $1: 200.000)$.

64. Planimétrie du projet de la conduite (1 ${ }^{\mathrm{e}}$ sect.)

65. Id. id. id. (2 $\left.{ }^{\circ} \mathrm{id.}\right)$

66. Id. id. id. (3) ind. )

67. Id. id. id. (4 ${ }^{\mathrm{e}} \mathrm{i}$. $)$

68. Profil en long des embranchements au Port Nilitaire et au bourg de Puerto Belgrano.

69. Profil en long de puis l'origine jusqu'ì la ville de B. Blanea.

Dépôt et captation des Eaux couliantes

70. Vue et plan du dépôt d'eaux courantes, station téléoptique, etc. (Echelle de 1:25).

71. Détails de construction de la tour de surveillance. (Echelle de 1:20).

72. Galleries de prise des eaux courantes, et autres travaux de forage eompris dans l'enceinte du Port Militaire. (Echelle de $1: 5.000$ ).

73. Captage des eaux dans les dunes de l'Observatoire Magnétique.

74. Conduite de la distribution des eaux rourantes dans les différentes zones du Port Militaire.

T5. Installation des pompes des eaux courantes.

\section{Egiouts}

76. Plan et profil. (Echelle de 1:100).

77. Coupes diverses et regard. (Echelle de $1: 20$ ).

78. Chambre régulatrice. (Eehelle de 1:20).

79. Détails des chambres régulatrices et de la chambre de décharge (Dessin d'exécution.) 
80. Détails de la bouche de décharge á la mer. (Echelle de $1: 20) .{ }^{*}$ (Id.)

81. Plans et profils. (Id.)

82. Détails des chambres rég'ulatrices.

83. Détails des bouches de registre, etc.

\section{Edifices divers}

84. Hôpital de la marine. Plan d'un pavillon.

85. 1d. Cuisine, lavoir et autres services annexes.

86. Id. id. id.

87. Hôpital de la Marine, Sous-sol de l'annexe du pavillon $n^{\circ} 3$.

88. Id. Trottoir (Maęonnerie).

89. Appartements du Médecin en Chef de l'Hôpital.

90. Chalet $n^{0} 8$.

91. Chalet $n^{\circ} 8$ bis.

92. Edifices pour les bureaux et appartements.

93. Maison no 23, pour enployés.

94. Maison $n^{\circ} \bullet 4$, pour employés.

95. Edifice pour les Postes et Télégraphes. Tue et sections.

96. Id. id. id. Plans et détails.

97. Entrée principale de l'Arsenal de Marine.

98. Ecole Umberto I, érigée par suscription publique.

99. Cilve magnétique à Puerto Militar.

100. Cimetière, four à crémation, colombier, etc.

101. Caserne de l'Artillerie des Côtes. Plan général.

102. Id. id. Tues et coupes diverses.

103. Poudrières. Vues, plan et soctions.

104. Id. Détails des murs et fenêtres.

105. Id. Détails divers.

106. Dépôt de munitions.

707. Appartements pour les employés des poudrières et du dépôt de munitions.

(*) Les planches 79, 80 et 81 contiennent les modificalions introduites dans le projet pendant la construction. 


\section{Projets divers}

108. Cale pour grands navires à Rio Santa Cruz, transformable en bassin de carénage.

109. Station Navale ì Rio Santa Cruz.

110. Ligne télégraphique à la côte du Sud ( $1^{\mathrm{e}}$ section).

111. Id. id. $\left(2^{\mathrm{e}}\right.$ id $)$.

112. ld. id. $\left(3^{\mathrm{e}}\right.$ id $)$.

113. Id. id. (te id ).

114, 115. Chemin de fer stratégique. Pont provisoire sur le Arroyo Pareja.

116. Plan géneral des phares et sémaphores à établir le long des côtes Atlantiques.

117. Phares et sémaphores à l'entrée de Bahía Blanea.

118. Phare du Cap des Vierges.

119. Tour métallique pour les phares.

\section{2。.- Album photographique}

1. Plage de Punta Alta (avant les travaux).

2. Edifice des eaux courantes. Tour de surveillance.

3. Id. id. id. id.

4. Construction du radier en béton du Bassin de Carénage.

5. Revêtement en granit jusq'au premier gradin.

6. Id. id. id.

7. Entrée sud du Bassin, pendant la construction.

8. Id. Edifice des machines.

9. Pose des cales de quille et de carène.

10. Montage du bateau-porte intermédiaire.

11. Entrée sud, au moment de faire rentrer l'eall.

12. Entrée nord, et vue des ehantiers.

13. Enlèvement de la porte flottante et manoruvre de la porte glissante.

14. Chambre do recul de la porte glissante.

15. Darse, vis-ì-vis le bassin de carénage.

16. Darse d'entréo au bassin de carénage pendant la houle.

17. Houle contre la porte glissante. 
18. Entrée des eaux dans le bassin de carénage.

19. Vue du bassin pendant l'entrée du « San Martin 》.

20. Entrée du premier cuirassé dans le bassin.

21. Le «San Martin» coupant la guirlande.

2.9. L'entrée du bassin ouverte après l'entrée du «San Martin $»$.

23. Id.

fermée

id.

24. Porte flottante fermant la $3^{\mathrm{e}}$ section.

25. Cuirassé ì sec (poupe).

26. Vue d'ensemble du bassin et Edifice des machines.

2-T. Vue d'ensemble du bassin après la sortie d'un cuirassé.

28. Nôle provisoire à l'entrée du bassin de carénage.

29. Remorqueurs de la $1^{\text {e }}$ section du bassin de carénage.

30. Entrée du croiseur anglais «Cambrian» au bassin.

31. Cuirassé nord-américain «Iowa» entrant au bassin de carénage.

32. Id. dans le bassin de carénage, vu depuis l'entrée sud.

3\%. Id. id. vu depuis l'entrée nord.

34. Id. à sec dans le bassin de carénage.

35. Calage du cuirassé «Iowa» dans le bassin de carénage.

36. Poupe du «Iowa» et entrée sud du bassin de carénage.

37. L'ingénieur Villanueva (ancien Ministre de la Guerro et de la Marine, qui ordonna la construction du Port Militaire), au fond du bassin de carénage, en compagnie de l'Amiral Sumner du «lowa»

38. Chirassé « Iowa » à sec dans le bassin de carénage.

39. Poupe du cuirassé «Iowa» et Edifice des Machines.

40. Croiseur Newark» et yact 《Varuna», dans le bassin

4. Id dans le bassin de earénage.

t2. Id. vu de prone dans le bassin de carénage.

4.). Id. dans le bassin de carénage.

44. Mancuvres de l'équipage du eroiseur 《Newark».

45. Batean-école «Áarmiento» et cuirassé «Pneyrredón ».

46. Id. dans le bassin de carénage.

tr. Mur daccostement. Construction du revètement en granit.

4r. Id. En cenve.

49. Id. Comstruction du tunnel de la cunduite des eaux.

j). Id. Lin aeure. 
51. Edifice des eaux courantes, Tour de surveillance et Hîpital Naval.

52. Id. V'ue d'ensemble.

53. Château de serveillance, et première section de l'Hôpital Naval et Edifice des machines, etc.

54. Tue panoramique du Château de surveillance, de l'Hôpital Naval, de l'édifice des machines, etc.

5ว. Pavillon de l'Hôpital Naval.

56. Maison pour employés (juin 1899).

57. Id. (trois ans après les plantations).

58. École Humberto I.

59. Pont du Ch. de Fer de l'E. sur l'Arroyo Pareja. (en aval).

60. Id. id. (en amont.)

61. T'ue générale des travaux maritimes et mouillage de l'Escadre.

62. Phare de «Punta Mogotes». 


\section{-}


St. LOUIS EXHIBITION

(UNITED STATES OF N. AMERICA)

\section{ARGENTINE REPUBLIC}

MINISTERY OF PUBLIC WORKS

I)IRECTION GENERAL OF IIYDRAULIO WORIS

\section{PROYECT FOR IMPROVING}

\section{тü \\ NAVIGABILTTY OF THE RIVER URUGUAY \\ BETWEEN}

THE RIVER PLATE AND CONCORDIA

$\because+\frac{1}{i}$

BUENOS AIRES

157056 -IMPRENTA, LITOGRAFIA Y ENCUADERNACION DE JACOBO PEUSER

Calle San Martín esquina Cangallo

1904 



\section{Project for improving the navigability of the River Uruguay between the River Plate and Concordia}

\section{GENERAL REGIME OF THE RIVER}

Is this Commission has finished the survey of the River Uruguay between Concordia and Concepción del Uruguay and has further made a recognizance of the PRACTICABILITY OF THE PROJECT OF H. E. THE MINISTER. same between the latter town and its mouth, and though the studies of its regime only exist in outline, as the principal part of it, riz: - the precise levelling - by which the numerous observations of velocities of the current, as well as the relative propagation of the floods and tides can be coordinated with accuracy - has not yet been carried out, the Commission is however in a position to present to the superiority the results of the works carried out up to the present moment, which prove the practicability of the proyect of $\mathrm{H}$. E. the Minister ats described in the Memory presented to the H. Congress in 1899 .

The observations made at the different gauges, which this Commission has placed in the River Urugulay, not only have coroborated the vague opinion which existed APPROXIMATE LEVELIING WITH TIDE OBSERVATIONS that some tides were felt in the Port of concepcion del Uruguay, but have elosely shown the importance of the propagation of the tidal wave: not only as to the reconlarity with which they oceur, but also as to their amplitude.

'This circumstance - a direct levelling not existing has made it possible to utilise the tidal observations 
taken during a month in a period of low waters, which was noteworthy for its durition-from the end of December 1900 to the end of May, of the present year-to determinate approximately the general slope of the river.

To arrive at this result, the observations of February of this year have been selected because the river during this month did not undergo variations of importance in its discharge, the changes in height at the gauges between Nueva Palmira and the Estancia Humaitá being solely caused by the propagation of the tides.

Supposing the geometric place of the high tides to be a horizontal line, which may be admitted in the case of a river having a small slope, the average of the maxima observed at the gatges has been taken as ordinates in a downward direction and joining up the ends of the ordinates obtained in this manner, the relation of the zeros (planes of reference) at the different gauges has been found, which has allowed to refer them to that of Nueva Pahnira (which is $0.28 \mathrm{mts}$. below the zero plane of reference of the Riachuelo).

The result of this operation is that the zero of the gatuge of the Island of Sauzal, Banco Grande and Uruguay appear to be 40,53 and 54 centimetros respectively above that of the gauge of Nueva l'almira (Sheet $\mathrm{N}^{\circ}$. IV).

The average minimum for each gauge has also been taken and by locating the resulting heights with regard to the zeros of the ganges, the geometric place of the low tickes corresponding with the observed oscilations has been established, which mean amplitude in this manner has been determined lor each gauge.

By establishing the relation of the zero (plane of reference) at the rlfierent ganges erected as far as the Estancia Humaitá (in front of Culaviyu R. O.) as well as by a direct levelling over a distance of $14.350 \mathrm{mts}$. between the estancia Humaitá and Nueva Escocia, and by calculating the slope of the river supposing the existance of a mean velocity of $0.15 \mathrm{mts}$. between the latter platce and the foot of the Corralito Bar and by another lovelling of this Bar where there exists a difference in level of $0.40 \mathrm{mits}$, the general slope of the river Uruguay botweon Concordia and 
Palmira has been approximately determined and also by doing so it has been possible to draw its longitudinal section.

When the longitudinal section of this part of the river and the instantaneous sections of the maxima of the ordiINSTANTANEOUS SECTION OF THE PROPAGATION nary and extraordinary tides in every station has been drawn, the propagation of the tidal wave appears very distinetly.

From the eximination of this drawing results that at Nneva Palmira the first high tide is the strongest, the dillerence between both becoming less as they propagate in the river Uruguay, but it also happons that they are reduced into a single one, or that they are no longer felt on alecount of the influence of the winds.

It may also be observed that during the ordinary tides the quantity of water discharged during ebb is greater than that entering during flood, the contrary happening during the extraordinary tides. when the river goes back to its ordinary level alter 3 or.5 days as may be observed in the curves representing the heights of the water, a circumstance which greatly favours navigation of the river Cruguay during the periods when the river is low.

Observing those same curves, it may be seen that the ordinary tides without wind and only aused by the lunar atraction disappear near Nueva Palmira (6 or 10 centimetres of height) meanwhile the extraordinary tides under the influence of the winds of the end. and 3rd. quadrant arrive casily at Concordia and may reach at this port a height of more than one metre.

The slopes corresponding to the different heights observed in the various sections of the river Uruguar, have also been deternined (Sheet III and IV) and the mean slope during ordinary high river results to be $0.06 \mathrm{mts}$. per kilometer between Concordia and Nueva Escocia and 0.01.) mits. between Banco firande and Fray Bentos. 
Table of the high tides in the different ports, average height of the wave and its velocity of translation

\begin{tabular}{|c|c|c|c|c|c|c|c|}
\hline PORT AND PLACES & \multicolumn{2}{|c|}{$\begin{array}{l}\text { TIME OF TIDES } \\
\text { AFTER THE MOON } \\
\text { HAS PAST TIIE } \\
\text { MERIDIAN }\end{array}$} & 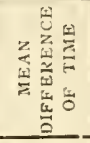 & 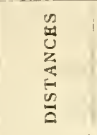 & 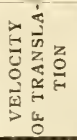 & 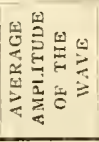 & OMsurtitious \\
\hline & H. & $\mathrm{H}$. & H. & Kil. & $\mathrm{M} / \mathrm{S}$ & & \\
\hline Buenos Aires.... & 6.20 & 19 & -5 & - & - & - & \\
\hline Nuera Palmira... & 9.57 & 22.13 & 5.10 & 101 & -4.43 & $\underline{0.6 t}$ & \\
\hline Sauzal Island (PB) & 15.25 & 3.05 & 4.15 & 83 & $\overline{5.43}$ & 0.48 & $\begin{array}{l}\text { The distance } \\
\text { between the } \\
\text { Sauzal Is. }\end{array}$ \\
\hline Uruguay..... & 19.40 & 7.20 & $\overline{3.15}$ & $\overline{33.40}$ & $\overline{2.86}$ & 0.45 & $\begin{array}{l}\text { land and } \\
\text { Uruguay is }\end{array}$ \\
\hline Colón. & 2.2 .55 & 10.35 & $\overline{7.30}$ & $\overline{75.70}$ & $\overline{2.80}$ & 0.45 & \\
\hline Nueva Escocia... & - & 一 & - & - & - & 0.21 & \\
\hline
\end{tabular}

Length of river in which the ordinary tide is felt . . ................ . 293.10

CURVES OF THE HEIGHT OF WATER AT THE DIFFERENT PORTS.

The curves of the height of the water at all the gauges, placed since the creation of this Commission, has been drawn, and also those at other gauges of which existed records from years before, as at Fray Bentos. Concepción del Uruguay and libres. The diagram of the principal ganges are shown ( sheets V. VI, VII, VIII \& X).

Studying the curves of the heights of the water it is very easy to account for the actual conditions of access to the different ports and also for the continuous valriations of level which the river undergoes owing to the tides rluring the periods when the river is low. It cin also be observed that the small rises, which in this ease take place above concordia. are not sufficient to ratise the level of the river below the Port of Conceprion.

It may also be noted that, though the greatest rises observed in the River Iruguay generally coincide with a period when the Paranci is low and vice versal, the fall of the water in the first named river is more considerable when the above mentioned relation does not exist. which is only is ronsequener of the small slope of the River Uruguay. 
The hydrometric observations are completed by diagrams of the metereologic observations carried out at the Port TEREOI.OGIC of Concepeión del Uruguay (Sheets XI and XII). With their aid it can be seen that the direction of the reigning winds and the general orientation of the river are the same. Their intensity, frequency and duration are indicated in sheet XII.

The approximate velocity of the propagation of the rises of the river between the principal stations considered results to be: - between Paso de los Libres and Concordial two days, between Concordia and Concepción del Uruguay one day.

The hydrometric observations have also been utilised to plot the corresponding heights of water for the Stations Concordia and Concepeión del Uruguay (sheet No XlII).

For the determination of the velocities of the cumrent, sections of velocity have been taken at the hydrometric stations Nueva Escocia and Concepción del Lruguay as well as at the different bars of the river (Sheets XIV \& XV).

The section at those two ports have allowed to plot the curves of the discharges and of the mean and maximum velocities in function of the heights observed for the Middle and Lower Lrmglnay (Sheet XIII). These studies have been carried out by the aid of a current meter system Woltmann with electric contact.

In comsequence of the quickness with which these obserrations nutust be made in the River Uruguay, as great variation of level may occur- within 24 hours during the periods of sudden rise of the river, they only consist in seven or eight verticals in which at each neter of depth relocities have been taken during intervals of two or three minutes.

The nature of the territory through which the River Unugnay flows is fairly consistent and the great proportion of mud which takes part in the formation of the islands and submergible grounds of the banks, makes them well able to resist the action of the current and explicates the relative stability of the different channels of the river.

The river bed of the River Uruguay is generally sand but in the lower Uruguay between the moutl of the Rio 
Negro and Fray Bentos mud is found over a great extension especially in the shallow parts which the navigators caracteristically call «El Barrial». The bed of the creeks and smaller channcls as far as Concepción del Uruguay is also mud.

Gravel. In the bar «Altos y Bajos» the suction dredger showed the existance of gravel at a depth of six meters under the zero of the gauge and the columns of the jetty of Concepción are placed in the same material which is sitnated under a layer of sand about 2 meters thick.

Going up stream the gravel appears more frequently and forms between Nueva Escocia and Concordia nearly exclusively the river bed.

It may be stated that, except in the stone bars of Corra lito and Hervidero», the Middle Uruguay does not bring down gravel during the great flows of water and that the gravel which is found in the river bed is not brought down from great distances but from both banks where layers of this matter are found at the surface of the ground or under a thin layer (cap) of humus.

The shallow parts formed by gravel of a diameter from 3 to 5 centimeters are specially found in the part of the river where the underground on account of its hardness has not been excavated and acts as a weir. This gravel forms a conglomerate were great velocities of current are observed.

Where the conglomeration does not exist, the sand, the

OF SAND BY THE AID OF SUCTION DREDGERS.

Downs. weight of which is about $1500 \mathrm{~kg}$. per cub. met., is easily raised by the suction dredger $\mathrm{N}^{\circ} 11 \mathrm{C}$, whose speed of water in the suction pipe is only 3,50 meter's per second. The specific weight of the sand causes it to deposit quickly in the hold of the barge and only a very small quantity flows over board back to the river.

At certain places the sand forms downs, as for instance on the Oriental coast at Nueva Palmira on the Nortlr and Soutl side of the Arroyo Negro and on the Argentina Coast north of the jetty of Concepción del Uruguay, on the island «Marineros» opposite Paysandú and at the canchas of Pepeají and San José.

The sand banks in the river contain a great amount of quart\% which does not allow any vegetation, they are easily 
shitted by the winds and their height roos not exceed 1,80 mits. above low river.

The stones or rocks, found in the river Lruguay may Rocks. be divided into two classes:

$1^{\text {st }}$ those wich originally formed part of the smperior layer of the ground and through its socavation when the liver bed was formed sumk down to the place which they actually occupy; $2^{\text {nd }}$ those which belong to the inforior layers and form compact banks.

The first are sundy and have more or less the hardness of grindstones, for the reasons given before they are louse stone and form heaps that can be extracted very easily.

The second are equally sandstone and those of the ( $0^{-}$

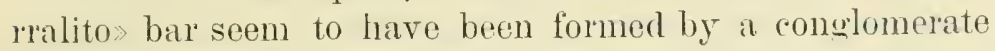
of limestone the softest parts of which has been dastroyed, the harder remaining and these once being silicified, besides getting firmer, have adopted irregular shapes. For this reason they are so dangerous to the hulls of the vessels.

There are also heaps of stones below the port of Paysandu and at the mouth of the Arroyo Sacra on the Oriental coast, and on the Algentina coast below the Arroyo Urquiza. Those stone heaps form the breakers of Paysandú, of the «san Francisco bar, of the limekiln Colombo, of Pepeaji, and of the arroyo Spina or «del Griego".

The sandstone in beds has been found by bolings at Chapicuy and in the Port of Concordia.

The stones of the Hervidero and Salto Chico are in some parts loose and in others they form beds: their texture shows rather a plutonic than a sedimentary origin. 'They are very hard in comparison with those named before.

\section{ACTUAL NAVIGATION}

The actual navigation of the River Lruguay consists of: the ocean navigation which goes to below the san Francisco bar and the coastwise navigation wich reaches to Concordia (Salto more correct).

The ocean navigation is actually done by ressels from Ocean navigation. 
700 to 1000 tors of effective load, and of a draught of $18 \mathrm{ft}$. as maxinum.

A serious inconvenience for vessels above cortain draught is the «Barrial bar situated below Fray Bentos, where the mean draught is only 17 feet, though vessels can cut their way through this bar drawing two feet more. (see page 16).

Before de dredging of the Banco Grande» and «Altos $y$ Bajos» bars was carried out, the captains of the vessels stipulated in the shipping contracts that the vessels should be lightened or their cargo be completed below the first mentioned bar. To-day this inconvenience has disappeared.

The coastwise navigation is catried out: 1st. by river NAVIGATION. steaners, which belonged successively to the following Companies: «Salteña, «La l'latense», «Nacional de Navegación á Yrapor», and «Mensagerías Fluviales del Plata and which are-now all belonging to Mr. Nicolás Mihanovich: s) nd. with lighters specially constructed or made up from old steaners, out of service, and which are towed, and $3^{\text {rd }}$. with the smaller coastwise vessels. Nearly all the river steamers ran before in the River Uruguay, the navigation of which used to be limly active on account of the numerous slaugtherhouses situated on both binks and also for the reason that there existed no other economical communication with the ports of Buenos dires and Montevideo.

river staamers. At present and in consequence of the paralisation of the slanghterhouses and the construction of railways in the Oriental Republic, which mite its Capital with Paysandú. Salto and the Brizilian frontier, this activity has partly decreased but is still sufficiently important to occupy for the service of the river the steamers, Paris, Triton, Helios, Labrador', ('omercio, 'Tridente and others, which make weekly trips.

The dranght of the steamers with a normal cargo on board is ? foet, in which condition they ("an carry 800 passenger's and 5.50 tons ol merchandise.

Serral ports of the River I ruguay are situaterl on creeks and the cargo for them is transhipped from the lare steamers into smaller ones, which have sufficient areconodation for passengers and ("allogo. 
In the zone between Colón and Concordia the transhipping is done directly in the ports by means of boats and lighters.

The navigation as earried out by towed lighters is the most economical because, owing to their capacity from 300 to 600 tons, they are only manned by a crew of 4 men and a skipper. They are used for the transportation of grain and the produce of the slatughterhouses and generally do not go beyond Colón as those of special construction lave a dranght of 9 feet, whilst the others go as deep as 15 feet.

'The third eroup, formed by the smaller coasting vessels, deserves more protection from the Public Authorities so as to make it possible for them to compete with the steamers and lighters, the actual competition being very unequal. The number of vessel of this class, which play on the River Uruguay and frequent the Argentine ports are more or less close on 300 , they carry a load from 30 to 100 tons and draw from 5 to 8 feet.

The draught of all the coastwise sailing ressels that entered the Port of Concordia haring been taken, their average draught resulted to be from 8 to 10 quarts (from 1.73 to $2.16 \mathrm{mts}$.)

In order that the river steamers may go up river to Concordia it is necessary that the height of the water at the gauge of said port be 2,50 meters.

I luring the years 1898-1900 and the first half of the year 1901, the number of days during which the steamers had to tranship into the smaller ones at Paysandí have been 76 48-149 and 14: respertively.

In order that the coastwise vessels with a draught of 8 quarts $(1.73$ meters), which are the more numerous, mily pass the bar of Chapicuy, it is necessary that the wange at «Nueva Escocia» marks 0,86 meters of water.

This navigation was paralized during 29 dars during' the year 1900 and 63 days during the first half of the year 1901: during the last period there was during 2:) (onsecutive days less depth than is necessary for the draught mentioned.

'There were even days during which navigation at the bar of Chapicuy wats completely stopped and passenger's had to continue their royage in boats.

INCONVENIENCES AND PARALIZ. TION SUFFERED BY NAVIGATION. 
COINCIDENCE OF THE TIME DURING WHICH THE RIVER is LOW WITH THAT OF THE EXPORTATION OF THE HARVEST.

IUPORTANCE OF TRAFFIC IN THE A RGENTINE PORTS.

RESUME.

Is can be seen from the diagrams of the height of the water, the periods of the lowest rivers oceur precisely at the time of the exportation of the harvest. The losses suffered by commerce and navigation, specially by the coastwise, are in some cases enormous.

The amount of the yearly traffic of the argentine ports on the river Uruguay is estimated to be 350.000 tons and this amount would increase if the condition of navigation were improved, for many of the cargoes, which before went to Concordia in transit with destination to Brazil and which are now sent directly by rail from Monterideo or Parsandí to the mentioned Republic (which will occur on a yet lareer scale once the port of Montevideo is finisher) would in such case again take the highway of the river.

Condensing the preceeding antecedents it will be seen that the slope of the river is insensible as the high tides are propagated as far as the port of Concordia, which, without this circumstance would not be accessible during about four months of the rear but for ressels drawing one metre.

For the same reason the fear disappears which might exist respecting the possibility that the level of the retained water upstream of the different bars will be lowered to a sensible degree alter their canalization.

The only ereat slope is that of the Corralito bar, but as we will see further on, when this bar will be cunsidered in detail, the work to be carried ont is specially one of rectification, the increase of section which will be given to the river at this place being depreciable.

On the other hand, the fict that the retained water above this bar might lower a few centimetres, will do no injury to the Port of Concordia, where there are no works and in front of which there is a depth which is at some places as much as 2.) meters.

Entering now into the description of each section of the river Uromar, the difficulties it presents to narigation, and the manner in which they may be remedied, will be studied. 


\section{ZONES OF THE RIVER URUGUAY}

The river Uruguay has been divider into the following zones, oi sections, which correspond to dilferences of the regime and distinct conditions of navigability.

Ist, louer Urugury: from its mouth in the River Plate situater above Nueva Palmira between Carbon Point and Chapirro Point, to Concepeión del Lruguay. Its extension is about 180 kilometer's (Slieets 5, 6, and 7 ).

2ud midalle Cruguay: From Concepción del Uruguay to Sialto Chico, situated immediately above Concordial, its extension is about 160 kilometers (Sheets 2, 3 and $t$ ).

3rel "pper Lruguay: From Salto Chico up river. Its extension is 4o kilometers (Sheet 1 ).

\section{LOWER URUGUAY}

The Lower Uruguay has again been subdivided into two parts, which differ greatly between eacls other: the first goes from its mouth to the mouth of the river Gualeguaychú, and the second from the mouth of the river Gualeguaychú to Concepción del Lrugruay.

The first section embraces an extension of 93 kilometers with a width from 8 to 10 kilometers forming a great lake crossed by a relatively deep channel, but which width is reduced in comparison with the width of river.

This circumstance and the curves of the channel and its banks which are often very steep explain, the great difficulties which this part of the river presents to its navigation with ocean-as well as with coastwise ressels.

The ocean vessels never navigate this part of the river during night time, the river steamers however havo to do Ist. SECTION.

From the mouth of the river Uru. guay to the mouth of the Gualeguaychú.

Difficulties for the navigation. so in order to pass during the day the bad bar's formed 
of stone of the Middle Uruguay, also some coastwise vessels do the same if they have skippers on board who know this part of the river well. This narigation is done by taking directions which are from time to time controlled by the sounding lead.

Buoys.

some buoys, marked on the English map, and which have been placed by the Oriental Gorernment, exist, but they disappear frequently, because the side wheels of the river steamers often destroy them.

As far as the depths, indicated by the mentioned map, are concerned, they are accurate and so are the directions of the channel; the only observation to be made being, that the soundings given are referred to the level of the ordinary water, mean while this Commission has adopted as plan of comparison, the level of the lowest low tide, which has been established from observations made during a period of 1866 days at the mole of Fray Bentos and from several referenees at Palmira.

The lowest tide observed at a gauge which has been placed in a arbitrary numner at the mole of Liebigs's Extract of Meat Factory, at Fray Bentos was 2.90 meters on the 24 th. of July 1896 at 7 h. p. m. Addling 10 centimeters to this level, in order to deduct three moters in whole figures from all observations, the readings with reference to the zero arlopted by the Commission has been obtained. From the curves of the heights of water ( Sheet VI) results that the plan of reference adopted remains albout $(0.30$ meter's below the mean of the extraordinary low tides observed.

In consequence there will always be more depth disposable for navigation than that indieated by the soundings on sheets $\mathrm{N}^{\circ}$. VI and VII.

As may be seen from the table, the tide propagates in this entire zone with the same intensity as in the River Platil which causes that at least 2 or 3 times each week the water rises to a kevel of about three or four feet above its ordinary level at low tides, increasing the depth indicated by the plans equally.

Floorts and high
ticles.

The ereat rises of the River Uruguay are at Palmira not so much noted as the highest tides of the River l'late, both 
may reach a height of about three or four meters as an avelige.

At Fray Bentos these differences of level are more or less the same, being 3,62 meters for the greatest rises of the river and 2,30 meters for the highest tides.

Up to the present time no special studies of the velocities of the ocurrent have been made in this part of the rivel, but it has been observed that, inconsequence of the influence of the tides, its velocity is sonetimes zero and even in a direction up river, when the river is low.

After having passed Curbon-and Chaparro points, going up river, the navigable chamnel is deep, wide, nearly From carbon point to Arenal Grande. straight and very close to the Oriental Coast, which circumstance makes its navigation easy till Arenal Gilande, where there is a wooden mole, is reached.

From here the channel curves towards the Argentine Canal de Márquez Coast, till after having arrived more or less in the center of the river it returns with a sudden bend towards the Oriental Coast in the direction of the point called «Cabeza de Negro». In the latter part of the channel, named the "Canal de Márquez » there is only a depth of 20 feet meanwhile before arriving at it there are depths of jo feet and more.

Navigation in front of this point is easy, but soon the channel begins to change its direction and to become narrower, forming what is called the « Amarillo bar which has only a depth of 18 feet by a width of about 250 meters, the river itsell at this place being about 12.000 meters wide. Atter having again changed direction the «Tarantanas » channel, the sides of which are very steep and where there is a depth from 36 to 52 feet, is reached.

In front of the Delta of the River Negro the chamnel goes nearer to the Oriental Coast and though forming a curve, this eircumstance and the fact that it is broarler at this part with depths varying from 28 to 40 feet, makes its navigation easy.

Above the Northern mouth of the River Nouro, North of the island Yruqueri the chamnel divides itself into two others named the English and the Caracoles chamnels.

The first is navigated by vessels of great draught and by the river steamels. At its beginning it is narow, 2.) meEnglish channel and Caracolos

Amarillo rass.

$$
\text { Tarantanas }
$$
channel. channel. 
ters, but afterwards it becomes wider and disappears in the bay into which the river Gualeguaychú flows. Its depths varies from 20 to 44 feet. The Caracoles channel being of easy navigation for being near to shore is utilised by coastwise vessels of small draught. The depth may be about 6 feet in its northerm mouth but its location has not been indicated on the plans as it could not be explored, the steamer of which the Commission disposed, drawing too much water. It may be observed that when going up river that meanwhile the Argentine coast is low and formed by mud, which is sometimes liquid the Oriental coast is exchusively sand or tosca.

c Barrial > bar.

In front of Gualeguaychú exists on the Oriental side a deep channel which is separated from the English channel by a shallow part which has been caracteristically called the «Barrial », with a depth of only 12 feet at the adopterl zero of this point.

The shallow place is indicated on the English Chart with 17 feet depth which may be found in this pass inconsequence of the tides and the facility with which it may be ploughed by the keels of the vessels to a depth of 2 feet.

This pass has not been surveyed; before the bar of « Banco Grande» had been dredged it was not considered to be an obstacle to navigation. which appears from the fact that the ocean vessels were chartered with a full cargo to below the last named bar. Neither is it mentioned in the nautical instructions of the River Plate of the hidrografic service of the French Navy. Till some 7 years ago the exportation consisted mainly in products of the slaughterhouses and the importation of salt for the same establishments which was done with sailing vessels from 14 to 18 feet draught, but since, notwithstanding the bad harvests of those very years, the direct exportation of wheat and corn started in the Port of Concepeion del Uruguly and as the tendency is to use vessels of the lingest tonnage possible in this trade, the «Barial» pass becomos a serious obstacle, though its importance lessened by the nature of the bottem and the frecuency of the tidles. Vessels with a draught of 18 feet may pass this bar in the proportion 
ats indieated in the oraplice table shown in the lespective drawing (Slleet 6 ). The quantity to be dredeed for a depth of 17 feet at the adopted zero by a wiolth of 200 metres is about 180.000 cubic meters.

As there exist immerliately below the pass a rhannel of a depth from 30 to 50 fieet, it is probable that in order to curry this work out, the suretion dredger " 11 C. > may be enployed, and that by making use of the periods of floods, the lifted material after havine been put in suspension will be carried away by the current.

In case this proves to be possible, the creavation might be carrier out, working night and day, in a short time.

It is intended to proceed within an early date with the survey of this pass and to make a trial with the nimed dredger. which trial will be the base of a plan which in flue time will be submitted to the superiority.

Once this bad bar has been orercome. narigation has no difficulties till past the port of Fray Bentos, the (-hannel being wide and deep almost following the oriental coist.

From the foregoing results not only that in the zone which has just bern described, the bar colled "barrial" with reference to the depth to be given to the Iruguay Inferior is the only bad one existing, but also that the rlifficulties with respect to the comse to be followed by navigation, even during day time. in ronsequener of the sinousities of the rhannel and becamse there are no lind marks. are many.

The most appropiate means to facilitate nawigation and to give confidence to the pilots who enter the river Lillguay with vessels of great draught is to mark the rhamnel over its whole extension with luminous buoys.

Ther ought to be huminous, in order that the ressols or river steamers dout sink or injure them by colliding with them during their voratges which in this section of the river ate alwalys during night time and which would be difficult 10 be aroided considerine the manner this zone is navigated duriug niwht time using the lrat and taking courses, going near the slopes of the chammel from one side to the other, which sides are the very phaces where the buoys must be located.

Necessity of buoying with lu.
minous buoys. 
According to the plan of this zone of the river. which has been specially prepared to project the buoying, 25 luminous would be sufficient to mark the navigable channel from the mouth of the river Uruguay to Fray Bentos.

Grenerally the sites indicated for the buoys are the prominent points of the channel and the places where the banks are the steepest, placing two buoys where the chamnel is narrow and dangerous. It the beginning and at the end of the projected channel in the Barrial p pass two buys will be provided. It will be noticed, that aceording to this project, there will be when going up river 11 buoys carrying white or green lights on the portside of the chamnel, 14 carrying red lights on the starboard side.

In concluding it must be acknowledged that for the exactness of the soundings shown on the plan, the observations made since the year 1896 at the gauge of the mole of the "Extract of Meat Faretory at Fray Bentos, have been of the greatest utility and that they were most kindly supplied to this Commission by the Nanager of satid Factory.

The Gualeguaychú The first Irgentine port when going up river is that of Gualemaychu: it is situated some on kilometers from the mouth of the river of the same name and some 33 kilometers from the bay of Fray Bentos (stheet $f ;$ ).

This river has a mean width of 100 neters by a mean depth of s feot. It has only one notable curve, but as its radius is 3101 meters, it is of no considerable inconrenience to the actual narigation.

The dilficulty which ressels of a regular draught meet consist in two shallow bars of stone; one of then is neall the muth of the river. the other in the noighbourhood of the port. The first one lis an axtension of 200 meters and is covrered by only thee lieet of water when the river is very low.

liesirles those bats there are isolated locks which am unperfectly known spread orer the whole leneth of the river and whirets ante dimeremous to naviention.

To the difficulties of the mentioned river is to be added the rextrnsive bar existing at its mouth. which, formed by mud, makes navigation impossible when the river is low, 
by rlosing the entrance of the river completely for vessels of mole than is feet of dranght. This circumstance howere]' helps to decrease the dincers arising from the existine shallow places in the river where there is stone.

'This second part embruces an extension of si kilometers. which differs greatly from that described before. Inmediattely above the mouth of the River Gualeguaychú begins the formation of islands which increases when woine up) 2nd. SECTION. From the mouth of the river (intale. guaychú to Concepción del Uruliver and which istands separated by several arms or creeks form in the neighbourhood of «Las Thes Bocas 》 (thr three mouths) a delta with a width of 12 kilometers which is completely flooded when the river is hioh.

'This circumstance renders navigation in this part easy for the pilots, in consequence of the many landmarks which the banks offer to then.

Alrady in this section the ereat difference in level is observed during ereat flows of water. The greatest slope observed is 0,04tit meters per kilometer, the mean slope when the river is high is 0,0195 between Fray Bentos and «Banco Girande » and 0,035 meters between the latter locality and Concepción del Uruguay (Sheet III).

The nean relocity observed in the bar of <Banco firande $>$ was 0,714 meters and the areatest ras 1,16 meters when the lerel of the river was 2,70 meters.

In this latter part with the greater slope, are the different sand bars situated, which are an obstacle to navieation with ressels of great draught.

The influence of the tides is felt in the port of Concepcion del Urugualy to a height of 2 meters at the gange. their mean height, when the river is low, beine 62 centimeters.

From Fray Bentos to the North point of the Zapatero Island there is only one chamnd for the navigation, and the diffienly in this part consists in avoiding the south part of the Abriego lsland in front of which the "Lnzué» port ( also ralled Abrigo»or « Nandubayzal port), is situated, which was examined by a commission of the Nary in the year 1882.

1 litte above the Kapatero fsland naviogtion ean solocet from two chanmels which are called the «Boca Chical ? and the \& Filomenal channel. The first named clummel 
owes it name to its narrowness between the «Boca Clica Island and the Southern extremity of the «San Lorenzo 》 Island.

Channel of the Boca Chica.

The Filomena channel.

Channel of the China.

Bars of Tala and of the Calderon island.
This is specially used by the coastwise navigation, and also by the river steamers when the river is high. It is preferred by navigation notwithstanding the danger of colissions with river steamers, because it is more protected and shorter than the Kilomena» channel.

Its minimum depth is 9 feet, which is lound a little above the Northern point of the island of the «Boca Chica 》.

The «Filomena» channel owes its name to the vessel «Philomel , whose Commander B. J. Sullivan, of the British Navy recounised it for the first time in the years 1845 and 46 .

It is the route followed by the vessels of great draught and by the river steamers when river is low. Its smallest depth of 19 feet is found at the entrance of its passage between the island of the "Burro and of the "Filomena trande».

Both channels join to separate again a little further on, at the point called the "Tres Bocas».

The one nearest to the Aroentine coast continues under the name of arcek of the C'hina $»$ and terminates in the interior port of Concepeion del Uruguay.

There are two bars which difficult navigation of ressels of !) feet dranght in the channel of the China , these are the bar of "Tala and that of the "Calderon island, the latter being situated in the very port of Concepcion del Iruguay. The bed is formed of mud and the depth at the first named bar is 5 and the second $31 / 2$ feet at the zero of the eatues at those places.

Is the river steamers and roastwise vessels could take this ronte when entering or leaving by the access channel to the interior port of Concepeion del Uruguay, dischalrging or taking their arreg there, it wonld be convenient to deepen the last mamed batris aretl as the channel of the China» (which actually las only at depth of 8 feet) 10 9 leet, which besides other adrantages, would benefit the pert of ('apalen. Campichnelo and l'iedritas, which ance ntilised hy rolonies and important eattle ranches of the neighbouthoort. 
The other channel follows, from its sepal'ation above the srincipal channel. "Tres Bocas» the Oriental coast and form the most important and rleepest arm of this section, of the river. It is used by the general navigation of the river.

It is comnected to the «China channel by virious arms as those called the \& Colon the s solitaria », « Cimpichuelo» and « Cambacuá ».

It was this part of the river which offered the greatest obstacles to the navigation of great draught, as there existed sand bars where the depth was reduced to only 13 feet.

At present part of these obstacles have been removed. only some of less importance remaining.

They are the following:

The bar of "Roman» with 16 feet of water at lowest The ckoman bar river, is situated in front of the "Bonfiglio island. The extension is only 400 meters and in order to remove it and to form a channel 17 feet deep by 200 meters wide a maximmm quantity of only 15.000 meters cube has to be dredged.

'The bar of "Banco Grande.. where there was only a The Bar of Banco depth of 13 feet, las been dredged to 18 feet and is marked as well during day - as at night time by beacons placed in the line of the course to be followed.

The survey of the "Montania bar has already been The Bar of Mon. carried out and a chamnel of 17 feet has been formed, but in consequence of its sinuosity there is practically only a depth of 16 feet.

In order to straighten the channel and to bring its deptle to 17 feet over a width of 200 meters it will be necessary to dredge a cube of $90.1100 \mathrm{M}$.

By decree of the 16 th of August 1901 its rectification within a cube of $10.000 \mathrm{~N}^{3}$ has been provisionally autorized.

The chammel has been marked at starboard sicle with three buoys numbered 2,4 and 6 .

The Altos \& Bajos» bar, which was a similar obstacle the cAltos \& Baas the Banco frande» batr has been deepened and marked joss bar. by beacons in the same manner.

Before arriving at this bar and at the mole of the port of Concepcion del Uruguar. there exist three plares with a depth of only 17 feet. 
Works to be carried out.

Dredging

Buoys and Beacons.
The zone between Fray Bentos and Concepcion del Uruguay is, as we have scen, more easy to narigate than the one which has been considered first, as the proximity of the channel to the coast allows its direction to be followed, but on the other hand there exists several sand banks which must be dredged and bnoyed.

The dredging has already partly been carried out and its conservation has given good results as well as the system of the beacons and buoys used.

It is necessary to place buoys at the following places:One at the South part of the "Abrigo island in order to aroid the shallow part at the extremity of this istand.

Three in the Filomena chamnel. The first one carrying the number 32 to mark the direction to be followed in the middle of the river', the second to mark the enrve formed by the channel and the third one in the narrow and shallow month between the "Burro and the Filomena Grande $\gg$ island.

Two in the «Roman pass.

One in the bar of Banco crande in order to complete the demareation of the beacons, marking the Northern end of the channel, which is very narrow.

Four in the Montana bar.

One below the Altos y Bajos bar to mark the slope of this bar: and finally one nearly in front of the mole of Concepción del Uruguay to mark the chamnel only 17 feet deep in the middl of the river.

The number of the buoys necessary to be placed amount therefore to eleven at starboard and two at port, making a total of 38 buoys between the River Plate and Concepción del Crugnay, which must be luminous for the same reasons as given with respect to those projected for the zone between the River Plate and Fray Bentos. 


\section{THE MIDDLE URUGUAY}

The zone of the river, which has been called the Middle Lruguay begins at Concepción del Uruguay, this part being the terminal port for Ocean navigation and because a little higher up river at the Oriental Port of Paysandi the transhipments of the ressels begin, which continues till Concordia.

It first, in consequence of the dredging in the shallow places of the "Almiron Grande and «. Iminiron Chico" bar. carlied ont by the Oriental Govermment to a depth of 15 feet, it was projected to give the same depth to the san Francisco bar, which obstaculises the access to the Port of Colon, but afterwards as it appeared that those works of canalization had not given a satisfactory result for want of maintenance and buoying, this idea was given up, it being decided to provide only a depth of $2.7 \mathrm{tm}$ ( 9 feet ) for this bar, which decision was approved by superior decree of the 15th. of June 1901.

The projected depth for this entire zone has therefore been fixed at 2,74 meters ( 9 feet) by a width of 50 meters ( the «San Francisco» bar excepted, which will have a width of 100 meters, which will be sufficient fol the proposed purpose as a glance at the curves of the levels of the water at Concepeión del Uruguay, Nueva Escocia and Concordia will show. It must here be observed that in all the plans and calculated puantities a depth of 3 meters has becu adopted in order to keep into accomt the imperfect cliss of work done by the dredgers, so as to obtain practically depths of 9 feet.

'Though the river Uruguay botween the River l'hate and Concepción del Uruguay has only been recognised, - only the principal bad bars having been surveyed - the part now under consideration has been completely sureyod in all its extension the corresponding plan having been drawn to a scale of $1: 10.000$ (Sheets $A$ to $N^{\top}$ ) and those of some bars at a scale of $1: 2000$ ( S'lieets $A^{\prime}$ and $C^{\prime}$ ).

The principal obsticles to navigation are several shallow Difficulties for naplaces formed by sindbanks, gravel or stone, which du-
State of naviga-
bility.

Projected depth of the bars between Uruguay \& Colon from Is to 9 feet.
Complete survey the river beween Concepción lel Uruguay s Concordia. 
ring the period of a low river cause great loss to navigation.

slopes. During the floods, the current is excessive, specially from Nueva Escocia to Concordia the mean slopes being 6 centimeters and the maxima being from $T$ to 9 rentimeters per kilometer.

Velocities of current.

Tides.

The greatest relocities of the current observed at the ports of Concepción del Uruguay, Colon and Concordia were $1.45,1,80$ and 2,20 meters per second, (orresponding respectively to riverheights of $5,+9,8,55$ and 12,56 meters.

The tides propagate with the same mean height to the Port of Colon as they do at Concepeion del Uruguay; the ordinary tides rearls to the Chapicuy bar and extraordinary as far as the P'ort of Concordiat.

In front of Concepción del Uruguay the river has an ample channel with a mininum depth of 20 leet, which forms a splendid roadsstead 7 kilometers long by 700 meters wide, which extends as fin as the extreme South of the *Amiron» island (sheet $N$ ).

At this point the river divides itself into two principal arms. In the Eastern arm, at the foot of the blufs, the chamnel maintains a great depth as far as the slaughterhonses "Casas Blinnos after which the depth decreases to 6 feet so that during a low river this arm is only navigable to the mentioned slaughterhouses (sheet $M$ ).

The Westem arm which is nsed by the general navigation, divides itself again into two arms, one nrar the $\mathrm{Ar}$ gentine roast and the other near the Oriental ishand ( Almiron Chico , pass: both have a depth of $1:$ feet, but the latter one is crenerally preferred as its navigation is easier.

Both last named chamnels mite again into a single one, which is wide and deep till the bar of « M lmirom Grande» has been reacherl.

This har, where there was before only a depth of \& teet at very low river, has, as hat been stated before, been dredged to 15 feet. Of this has remained a depth of 10 freet so that at present it is no longer an obstarte to the navigattion of the great river stemmers.

It is lowever not ret marked, which can be efferiently 
done with 2 beacons placed in line on the Irgentine coast and foul buors.

'This bad bar of ". Ilmiron Grande: having been passed and after the two arms of the Amiron lsland» lave joined - agian, the channel becomes wide and deep, having a depth of -2.) meters in the very port of Paysandí (sheet $L$ ).

There are on the Oriental shore near the Silcra» creek sereral shoales which remain above water when the river is low but which offer no danger to the navigators as they are ouside the general contse.

1)iflerent is the shoal situated above the port of Paysandin and wich is called the shoul of the «Curtiembre» (Tannery). On it grounded the river steamers «Helios» and L'aris». It can be avoided during day time, navigating a little westward of the line formed by the two tower of the Church of Paysandú. At present the shoal is marked by al buoy, which has been placed by this Commission.

The channel widens again till it reaches the lower end of the «San Francisco» island in front of the creek on the Oriental shore of the same name.

Here again it presents two arms to the navigation (sheet (I). The Eastern arm was before the one followed by the sailors, till it was discovered, that in the IVestern there is 2 teet more of water so that at present the first named is only used by vessels of small draught, which go to load lime or limestone in the River Queguay. The channel at thr. North point of the San Francisco Island, which in days before formed the pass indicated by this name, is now no longer used.

The Western channel has been surveyed in the years 189.5 and 1901, no notable differences in its configruration has been found.

It has a deptlı of 6 feet and being cmred caused the lrequent groundings that have taken place at this point. Upstream of the bar proper exist some sand banks, which beginning at the South end of the Queguay island, cross the river in the direction toward the great bank at the North point of the Hormos island.

The bar forms a weir when the river is low and the water flows in this case round the Nortlern point of the island of

The bar of San Franciscn. 
San Francisco, where it has excavated a channel of 50 meters wide by a mean depth of: meters. When the surface was levelled orer the distance of 4.50 meters in which the current is observed, a difference in level of $57 \mathrm{mili}$ meters was found. For this reason it may be hoped that once this bar has been canalized, the improvement will also be felt at the sand bank in consequence of the greater slope, which will be established in this part of the river.

Dredging work in
execution.

The dredging of the san Francisco bar which has been anthorized by decree of the 15th of June of this year (1901), is now in execution. The channel will be 100 meter's wide by a depth of 9 feet at lowest river. Three buoys have bcen placed to mark the old channel, but when the dredging has been carried out, their number must be previously increased to eight and completed by beacons in line on the Areentine coast until luminous buoys are provided.

Shoal of the San

Near the Oriental coast of the San Franciseo island exist

a shoal which is visible when the river is very low, but which presents no danger to navigation as it is situated outsicte of the general route.

Stretch of \&Colons and shoal of the limekiln of

With exception of a shoal situated on the Arqentine coast below the lime factory Colón», which nust be indicated by a buoy, navigation hereafter meets with no difficulties until arriving in front of O'Comnor's slanghterhouse.

A little above the mole of the slaughterhouse begins the bad bar-formed by sand and gravel-of Peruchoverne where there is only 5 feet of water when the river is rery low.

The work to be carried out here, consists in dredging $92.000 . \mathrm{X}^{3}$ in order to form a channel witls a section of al width of 50 meters in the bottom by leet depth when the water marks zero at the gauge. Is has been stated alrady before, this is the projected cross section for the channels to be opened in the bad bars till arriving at Con(ordial (sheet $J$ ).

The projected buorine consists in four buoys and a line of bearons on the Arwentine coast.

Stretch of the a Bat ca Chica) ()nee the mentioned bal has been passed, the navigation is easy, the deptly being areat till arriving at the boca Chica 
where orer a considerable distance great sand banks are met with ( Silheet $I$ ).

The deep channels terminates on the IV est side of the Bocar Chica island and the navigator las to take the smaller arm, which follows the East coast, which is formed by bluffs.

The depth of this channel varies from 3 to 5 meters and the maximum width is some 50 meters. lor which reason 3 buoys must be placed on the East bank.

Past the North point of the Pepeaji island there exists Shoat of «Pepeajis. on the Oriental shore a shoal, which protrudes some $80 \mathrm{mts}$ in the river, and which is indicuted by a buoy, which has been placed by this Commission.

A little below the Pepeaji creek exists a shallow place of sand and gravel, which carries the same name and where the depth is only 5 feet at the zero of the gauge (Sheet $H$ ).

In order to eliminate the obstacles which this part of the river presents, sereral directions have been indicated in the corresponding plan, but the direction corresponding to the smallest cube to be dredged and which maintenance will be the easiest, is. that actually followed by navigation. which also has the adrantage that it can be marked by a line of beacons on both shores, and four buoys. The cube to be dredged in this bar is $100.000 \mathrm{M}^{3}$.

Above the Pepeaji : bar the channel occupies the whole wirlth of the river and is of creat depth till the "Cancha Secal $\gg$ is reached which is a shallow placed formed by the sand. which during the great floods of water, is brought flown from the sandy bottom of the Merlo ereek and which is dropped again when the water of this creek loses its speed on entering the river ( wheet $G$ ).

There are two channels for narigation, one in the middle of the river and the other near the Argentine coast.

In the first channel there are $22.000 \mathrm{M}^{3}$ to be dredged and it can be marked with two beacons in line on the Argentine shore and four buys.

The sccond channel requires an excavation of only $\$ 000$ $M^{3}$ of heary aravel which is found above the arroyo «Palmar , but at this place, as well as above the spina creek there are shoals near the shore, these protude about 
80 meters into the river, and are only visible when the river is low.

As the channel near the Argentine shore is situated where the latter is of a concave form, it is to be supposed that its maintenance would be more easy than that of the other situated in the middle of the river, however vessels would not navigate it with the same confidence and it is for this reason that the dredging of the latter must be preferred.

Strech of the lime kiln of Barquins.

Bar of s San José

Stretch of the curve of «San Josés.

Bar of sombrerito $>$

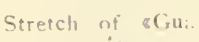
viyus.

Herealter-following the toot of the blulfis called the lime kiln of «Barquin»-.. the river has a wreat depth, which continues till the sand banks, situated at the Southern part of the island san José », are met with.

The cube to be dredged here is about $50.000 \mathrm{M}^{3}$ and alter this has been done the channel ought to be maked by beacons in line placed on the Aroentine shore and also by four buoys ( Sheet $G$ ).

There exists also a channel along the Oriental shore, but as its deepening would require the excavation of a greater volume than in the case of that on the Arontine side of the river, it has been decided to deepen the latter.

After this a wide channel of queat depth is found, till the bar called the Sombrerito has been reached.

There is little depth in this part of the river, and at present (1901), it is ten feet at lowest river. Contrary to the ceneral rule, the channel in this case is found in the convex side of the eurve, formed by the river, that means to say, very rlose to the Argentine coust ( Sheet $F^{\top}$ ).

This is the only place in the River Lrumay where chaneres in the riverbed have taken place, the channel running before mole towads the East, aceording to statements of old pilots.

It will be necessaly to rectily the chamnel here, which will require a dredging of about 6300 cub meters and to mark it with four buoys.

When this chamnel is passed, the rlirection towalds a stoney point, which inclicates the moutl of the ereek, Guaviyú, is followed, leavine the «Somblerito» istand on starboardside.

When passing the mole of the slaughterhonse, the depth decreases, and for navigatine it is necessary first, to keep 
the bow in the direction of the Gilariyg island and, after having passed the reek of this name, to keep it in the direction of the Arroyo (irande (sheet $E$ ).

The cube to be dredged, so as to make this bal suitable to narigation witl riversteamers, is 56.000 cub neters. It must be indicated by 8 buoys and a line of beacons on the Oriental roast.

The IVestem channel might have been selected as the one to be deepened, as its direction is nearly straight and perhaps its maintenance would be asier, but the cube to be dredged would be double as much. Also the slaughterhouse of «Guviyu beine an Oriental port, where the river steamers, which serve both coasts stop), ( which latter (circumstance ought to be kept in account): the deepening of the Western channel would cause them a loss of time in consequence of the curve they would have to make in order to aroid the great bank in the middle of the river. For this reason the intention is to deepen the actual route as it is thought that by doing so more practical results will be arrived at.

'The general depth of the river, which. as we have seen, diminishes atter the stretch of the blufts of sian Jose has

Stretch of \& Cha picuy $>$. been passed, does not increase amain alter the shallow bar of «tinariyú the middle Lruguay, the har of «Chapicuy», is met with at a short distance.

In the part of this Report, which lelers to naviugation Bar of schapicuys. (page 11) the great inconveniences, which this shallow part of the river causes during several months, have been mentioned and were it not for the extraordinaly tides, the influence of which may be felt in the Port of concoldia, it would make navigation of this zone of the river completely impossible.

This obstacle is formed by a shallow place (bill ) of sandy stone, which acting like a weir, detains the material which the enrent brings away from the bluffs of the plateat of "Artigas which excaration is the origine of the formation of the first islands of the middle Lruguay and of the sandbanks which form the bar of «Chapicuy».

From the borings, carried out at this bar, lesults, that the 
lock is formed by compact sand stone covered by 1,50 meters of sand. This rock has a depression which follows the very thatweg of the river, allowing therefore the drerlging of a channel with \& feet of depth with exception at the one place, where sand stone is found at a depth of 2.83 meters.

A little abore this bar, the depression formed in the hitrd sandstone seems to diride itself in a direction towards the Argentine coast in fiont of the arroyo «Mellado», passing between two banks formed by sand and gravel.

Even if it were truc that this depression continued till the cruve of 3 meters depth. ( which however is not likely to be the case), it is believed that a rhannel cut in this direction would be difficult to maintain, as it is sitnated between banks, the dimensions of which have augmented considerably as appears from a comparison of the figured plans of 1890 and 1900 .

Tho contray is observed in the chamnel passing the middle of the river, and as the bank in front of the island of Chapicuy $\gg$ has disapjeared, there is reason to believe thit once. When the bal of sand stone in the extreme south of the chanuel has been levelled, the result of this work will be the absolute maintenamce of its upper part, the more so as the projected direction corresponds exactly with the thalweg, which form corrusponds to the layer of sandstone.

Is for the other project in the rirection O. P., though jts upper mouth would have the adrantage of being better defined, the borings have shown the wround to be impenetrable to the borine tool at a depth less than 2. $\bar{\tau}+$ meters. reason for which the acceptance of this rlirection must be lejected.

The dumnel was therefore projected in the middle of the dopression, which is impenetrable to the boring tool,

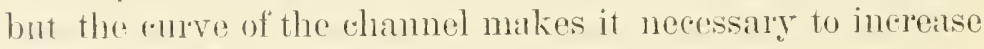
its width to 80 meters.

Comparison between the two directions.

It is vely uscful to rompare the cube necessaly to bo excavater for a curver as well as for an absolute straight channel which nnites the curves of 3,00 meters depth and which therefore is done below: 
Channel in a curved line

Ruck........ $16.000 \mathrm{II}^{3}$

sand and oravel. 256.000 ,

$272.000 \mathrm{M}^{3}$
Channel in a straight line

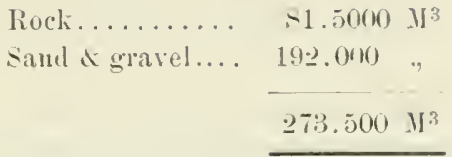

From these figures lesults that the channel in a curved line is the most convenient. as the difference in cube of sand to be dredged is little, where as that for breaking up and excavating sandstone is very visible.

In orde rto see the result which the opening of the channel mimht effect on the regime of the river in this palt, gauges have been placed which are based on a precise levelling which has been continued as far as the "Estancia Humaitá ».

With the observations which have been made simultaneously the mean slopes lave been dotermined for diflerent sections and the heights of water resulting from their examination that even if the formation of the uniform slope orer the whole extension of the bar were to take place, after the execution of the works of canalization, this would not unfarorable modify the resimen of the river in this zone, which, as has been seen, is navigable during a low river, not in consequence of the quantity of water it brings down, but for the periodical high tides. which maintain the water sufficiently high during three or foll days.

On the contrary, it may be taken for sure, that by opening the channel as projected, giving it a wiclth of 80 meters by levelling the shallow places of sandstone. this will help to maintain the upper portion, in consequence of the increased slope which will be established.

It is intended to mark this chamnel, in consequence of its curved direction, with ten buoys, which position will be referred to two fixed points placed with this object on the island of "Chapicuy .

The last maned shallow plate having been passed. the stretch of creruá river can be navigated with areat facility, following the 
Hervidero har.

Wi estern route 6 feet.

Eastern route 8 feet.

Marking of the channel. center of the river. till the arroyo «Hervidero» is reached. where the bottom formerl by rocks begins.

The extension of the Hervidero bar is about 3.800 meters, the principal shoals existing in the rery center of the liver" ( 'sleets $C^{\prime}$ and $C^{\prime \prime}$ ).

In order to aroid those rocks, navigation at present follows the Argentine shore, the rlirection being indicated by two buoys placed by the riversteamer Companies and the Oriental Gorernment. The number of those buoys is generally three, which are situated in the upper part of the bar; the first and the last are left to the W'est and the second one, which marks a great shoal which is visible when the river is very low, is left to the East. Following the described direction 6 feet of water will be found when the river is very low, but the bar ean also be passed leaving the geat shoal to the West and in this easc the maximum depth found is $S$ feet.

The last named direction, which is known by the pilots, is at present not used, not only for being more curved than the other but also because the navigability of this part of the river depends on the "Chapicuy» bar where there is only $21 / 2$ feet of water under the sime condition when the river is low.

Howerer it may become useful some diay when the other bals that of Chapicuy» included, have been deepened, but it will then be necessary to explore it first carefully in order to extract some loose stones, which are supposed to exist, besides buoying it.

In order to natke this bar mavigable in ronditions of perfeet safety, a nine feet chamnel in the center of the river has been projerted, which call be marked by signals placed in its direction on the Arentine sliore.

The greatest attention has been given to the marking of this barr, so that reswels may cross it during day and night with eomplete safety.

At present the steamers leave the docks of Buenos Aires at 10 o'elork a.m. with the object to arrive the next afternoon at Concordia and silto, where the operation of loading and unloading are immediately earried ont, in order that they may be able to undertake the return royage next day. 
"The delays the steamers suffer when woine up rivor, may eause them to arrive at the Hervideron" bar aller clark. oblinge them to anchor till the following day, losing by doing so one nieht, not to mention the losses and annoyances cilused to the passengel's.

()n the other hand it is very difficult to anehor buegs in this part of the river in consequence of the nature of the rivel bed and of the strong current-3 meters per second-when the rivor is high: and if this were to be attempted at least 30 meters of chain are required. the result being that in periods of low water those buogs could not indicate the channel with sufficient exactuess.

For all those reasons thr chamnel has heen proyected in the center of the river and it will be indicated by direction lines on the shore.

The rocky bar of «Hervidero, is mainly formed by loose stones. of an averaye weight of one ton, which cin be easily extracted with Priestmans excavators. The quantity to be remored is about $19.000 \mathrm{~m}^{3}$.

Mter having passed the list shoal of the Hervidero., narigation, in the curve formed by the river is easy, till the mouth of the arroyo Tuqueri Chico is rearhed (sheet $B$ ).

A little above this arroyo the bar carrying the same name ruqueri chico bar. is met with, which owes its existance to the little elevation ol the shoals and the concarity formed by the river (sheet $A$ ). The bottom consists of qravel and the cube to be dredged is 44.500 (-ubic meters. This dredging must be rompleted by establishing a direction line of beacons. to be erected on the Arentine coast, and 4 buoys:

Nivigating in the center of the river there is sufficient depth for the river steamers till arriving at the mouth of the arrove Yuquerí Grande».

In front of the mouth of said arrogro begins the bar of « Yuquerí Grande», a shallow place formed by gravel and Bar of Yuqueri Grande. remains of stones which the enrrent brings down from the «Corralito» bar (sheet $A$ ).

Two directions for a channel have been studied, the first one in a straight line, forming the prolongation of the (hannel projected in the rocky bottom of the Corralito» bar (Sheets $A$ and $A^{\prime}$ ) and for which a cube of $51.000 \mathrm{~m} .{ }^{3}$ 
must be extracted, but it will be noticed that this direction cuts a shallow place near the Argentine coast, where probably rocks will-be found.

For this reason it is believed that it is more convenient to adopt a direction partly straight and partly curved, following the thalweg of the river giving at the same time a width of 60 instead of 50 meter's to the channel. It is almost sure that adopting this direction no rock will be met with and the cube to be dredged will be reduced at the same time to $30.000 \mathrm{nn}^{3}$.

Is the bars of "Tuquerí Grande and of Corralito form in reality one single bar, being the first one, as explained before, a consequence of the second. it has been agreed upon to give the name of "Yuqueri Grande to the whole part which bed is gravel or snall stone, and that of "Corralito» to the part where the bed is completely of a rocky nature.

Corralito bar. Immediately upstream the «Corralito» bar is found, the formation of which is compact stone in the middle of which exists a narow channell. When taking the level of the water surfice in the part above and below the bar, when the height of the river water was 0,62 meters a difference of 0,40 meters was found over a distance of $2.237,20$ meters, that is to say a slope of 0,183 meters per kilometer.

The corresponding mean rolocity observed at the surface was 0.9-2 meters the greatest velocity, 1,26 meters per second. Other observations marte when the height of the river was 2,5) and 2,80 meters gave as a lesult velocities of 1,382 and 1.398 metris per" second.

In order to navigate the "Corralito» channel, the lollowing" buoys, all near the Argentine shore, will be placed when going upstrean, thee at the beginning and four at the end.

In the plan of the works for derpening permanently this part of the river lor naviation with vessels drawing y feet, a divection in a straight lino has been adopted, which follows as much as possible the existing chamel and reduces the excaration to be executed to a minimum.

The colbe af the material which must be broken up and excavated is 17.70 meters. The marking of this bar and that of Suguerí Grinde nust be done with buogs pro- 
virled with hanterns, which will be plated moler the charee of a special gutrd (watchman); the number of the buoys will be 122,6 on each side.

Ifter the Corlalito $\gg$ bar luas been passed there ane no more dilfienlties as far as Concordia, the depth in this port in front of the Harbour Police Office being 1.5 meters.

The river (ontinues rery deep) as far as salto ('hico but en the Arontine coast past the mole of the shaughtrerhouse of Concordiat there are many shoals amongst which despres to be mentioned specially the one called : Lal C'abillatda. It is met before arriving at the Oriental port of Salto, obstrueting the river and learing only an opening towalds the Oriental shore ol about 81) meters.

Is has been observed in the loregoing description, of the zone between Concepción del Lruguay and Concordia, the inconveniences that difficult navigation drawing ? feet are numerous, but with exception of the barl passes Chapicuy, "Hervidero , and Corralito, the rest can be easily removed. 'The marking of the chamnels to be opened is also easy and can be done by directions on shore, which alleadr have given good results at the bar of « Mltos y Bajos and «Banco Grimde .

From the quantities, which are wiven, results that the maximum cube to be dredged or excarated in the different shallow places is as stated in the following table: 


\section{GENERAL QUANTITIES OF THE WORK TO BE CARRIED OUT TO OBTAIN A DEPTH OF 9 FEET TO CONCORDIA}

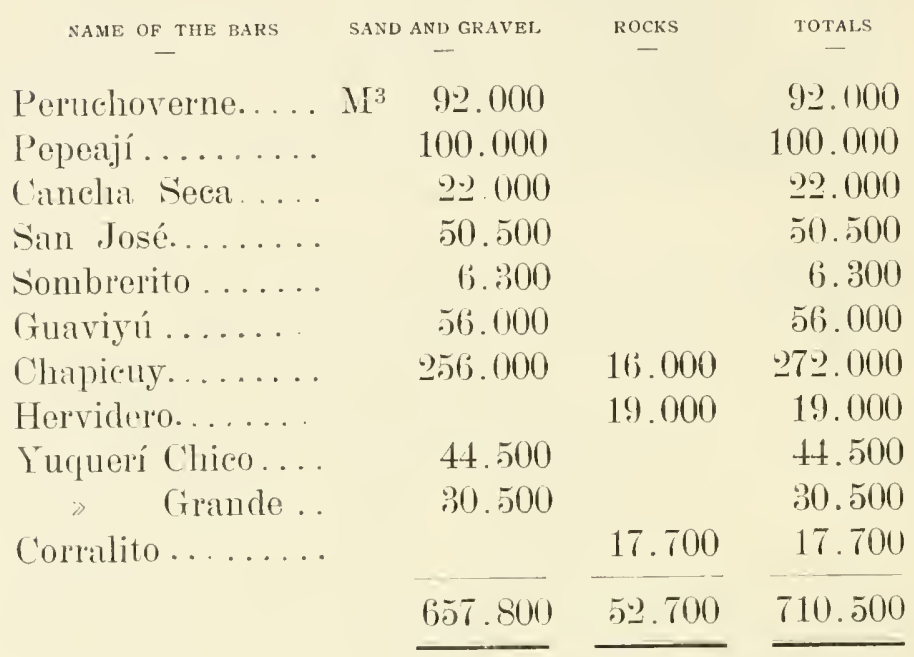

111 the cubes lave been calculater for a depth of 10 feet and have been increased with some $20 \%$ in the case of sand and wravel and with some $30 \%$ in case of stone, they represent therefore the maximum work and the complete solution of the problem.

\section{PROVISIONAL REDUCTION TO 8 FEET OF THE DEEPENING FROM CHAPICUY TO BELOW THE CORRALITO}

As it may lappen that it would not be possible at present to dispose of the necessary alements to mudertake the canalization of the bars which are of a stoney formation, the deepening of the bals of 《Chapicuy above the lattrer must be reduced at present to 8 feet $(2.40$ moters ).

By this provisional solution the cube to be dredoed would be reducer to some $500.0010 \mathrm{M}^{3}$, to which ought to 
be added unimportant work to rectify and to rean the eastern chammel of the "Hervidero" bar.

With a deptl of 9 feet at the bars situated between the Concepreión dol Uruguay and "Chapicuy and of S feet between the latter and Concordia, the conditions of navigations in those parts of the middle Uruguay would have improved considerably.

The coastwise narigation would no longer suffer from the ronsequences of a prolongated state of a low rivel and the port of Concordia would be permanently aceessible to it.

What concerns the river steaners, they would nealy always be able to reach the latter port, sometimes transhipping into liwhters would have to take place below the Corralito $\gg$ bar and mole exceptionally yet below the "Hervidero or «Chapicuy 》 bar, as easily can be romprobated by an examination of the curves of the height of water at the ports of Nuera Escocia and Concordia.

The buoying of the middle Uruguay uught to be carried out as far as the port of Colon with luminous buoys for the same reason for which this system has been proposed for the Lower Uruguay.

It would be necessary to place this class of buoys at the following points :

At the South point of the "Almirón " jsland. one At the North point of the Oriental island... one At the bar of "Almirón»............ four At the shoal of «Curtiembre ( Tammery).. one At «San Francisco» bar.............. six

being a total of thirteen luminous buoys in this section of the river. From Colón to Concordia it is intended to use cylindrical buoys 1.50 neters long by 1,00 meter dianeter, with sights and rudders : at nearly all the bars the bnoving would be completed by directions on shore, indicating the center of the channel, and which if provided rith lights, would make navigation of these bad bals easy even if during night time.

Cylindrical buoys have been adopted, as their construction is cheaper and because repairs can be easaly exeruted. 
Is the beacons in alingments can nearly all be erected in places which are out of reach of the highest water, their construction, installation and maintenance will be fairly economical.

\section{GENERAL PROGRAM OF THE PROJECTED WORKS}

By the aid of all the preceeding antecedents and the detailed list of the work to be executed for the improvement of the river to Concordia, the corresponding estimates have been prepared.

Determination of

For the pupose of establishing the schedule of prices for dredging, the plant which the General Inspection actually disposes of, as well as the cost of the work already carried out by this Commission at the bars of Banco Grande. Altos $y$ bajos and San Francisco, have served.

Breaking up and extraction of rock.

With reference to the breaking up and extraction of the bars of rock it is believed that the first operation can be executed with explosives and also by heavy bar's and rams, which are allowed to drop from some height and for which an installation can be made; the second with Priestman's crab excavators.

The use of the falling ram is indicated to level the shallow parts formed by sandstone of the «Chapicuy» bar, and that of the explosives to break up the blocks or layers of compact rock of the «Hervidero and Corralito» rock.

At the two last named bars and specially at the first one the work of extracting the stone will be notabaly reduced in conseguence of depth existing near the plitces where the explosives will be used.

The Pricstman's rab excavators can be erected on and worker with perfect ease on board of steam hopper barges, the holds of which onght to be lined before hand with timber in order to transport and discharge the extracted matorial.

In this rondition and hy working in a rational manner, it is brolieved that the excaration and extraction of the stones can be done at a maximum cost of 5 dollats national 
currency, and that this price will be notably reduced if special tools could be provided, with which also the work of the improrement of the Upper Uruguay rould be iniciated.

With relerence to the workmen. as labourers, saibors, miners, firemen, etc. it can be said that they ale of a very good cliss and that they may be secured in the different ports of the River Umguay. For this reason the interruptions work caused by the great rises of the river, will be of little influence to the cost of the works.

The ordinary buoys which are intended to be platerd are of about $0.750 \mathrm{M}^{3}$ of displacement, and will be anchored with chains of 25 milimeters diameter and of a length equal to double the depth at the highest river.

'The towers or beacons for indicating' directions have been designed of angle iron $\frac{80 \times 80}{10}$ milimeters and are 8 meters high.

The advantage of their use (besides an other principal onc. which will be indicated further on ) is that they can be changed into a luminous demarcation under economical conditions.

The huts, which are provided for guards, are destined for the watching and the service of maintenance of the demarcation of the principal bars of Chapicuy, Hervidero and Corralito.

In order to estimate the cost of the luminous broys to the Port of Colon, which port is navigated by the riversteaners during night time, the prices of the contraret with Messrs. Dirks \& Dates of the $10^{\text {th }}$ of January 1899, for a similar work executed in the River Plate, have been taken.

The total cost of the works mentioned amount to seren hundred and thirteen thousand eight hundred and five dollars national currency ( $S 713.80 .5 \mathrm{n} / c^{\circ}$ ) and Two hundred and five thousand four hundred and seventy three aregentine gold dollars ( 5 205.473 gold dollars).

In order to carry out the works within two rears it is necessary to complete the dredging plant of this Commiscion with the following elements:

Total cost of th works.

One bueket dredger of an average monthly work of 20.000 cub. meters $(\mathrm{C}+)$. 
()ne tomboat ( $204 \mathrm{~B})$.

Four ordinary hopper barges.

One mud pump, transformed into suction deedger ( C 12).

One steamer for inspection ( B 105 type ).

With these olements added to the dredger $9 \mathrm{C} \gg$ and 11 (' a monthly cube of 84.000 meters may be rlredged and ralculating 8 montlus of work for every year ( taking into account the losses caused by high water or repairs ) a total of $1.344 .000 \mathrm{M}^{3}$ will be excavated at this rate, which is a difference in favour of about $200.000(\mathrm{cub}$. meters. Therefore as lar as dredging is concerned, the working plan can perfectly be realized.

Besides these elements, the acquisition of which is foreseen in the price calculated for this class of work, it would be useful if for the breaking up and extraction of the stones, two steam lopper barges were provided.

What the ordinary buoys and beacons concerns, considering their quantity it might be convenient to have them made hy private contractors so that they will be promptly ready for placing, and facilitate the execution of the works.

Te plan of the work having been clearly explained, its

Time it will take to canalize the river. practical results might be doubted, specially with regard of the deepening of the shallow places.

It has been observed when describing the River Lruguay and the different bad bar's, which are an obstacle to navigation, that the river has a very reduced slope and that its banks are firm. The shallow places with their details of orientation and depth have remained the same, as has been proved by comparing diflerent surveys made before. with those made by this Commission.

The cause of the relative stability of the shallow places and specially of these where the direction ol the current is always the same, is the great adherence and conglomerittion between the materials, which is so great that the suction dredger of this Commission is not able to lift them, though the velocity of the water in the suction pipe is 3,50 meters per second.

It is therefore expected that the canalization of the bars, which are in these conditions, when executed, will be of easy maintenance. They represent more than half the cube 
to be dredged as may be seen from the following list : San Francisco (129.000 $\left.\mathrm{M}^{3}\right)$, Peruchoverne (92.(1)(1)), I'(upeají (100.000), Clappicuy (297.000), Yuquerí Grande (2).0.000).

With reference to the maintenance ol the other birs, which are formed by the rhange of the curent atecording" to the different heights of the river as for instance that of the Cancha Seca (2.2.000). San José (50.500), Sombrerito $(6.300)$, Guariý $(50.000)$, Iuquerí Chico $(44.59)(1)$. it is believed that it will be necessary to dredge after each great rise of the river, about $60.000 . \mathrm{I}^{3}$. supposine that the filling will represent a third part of the cube originally taken out. Besides, it has already been proved that for maintaining the hars of Banco frande and Altos $y$ Bajos the working eapacity of the suction dredger is one third more.

It is therefore possible to assure tlat, with two suction dredgers, the C 11 and an other one of those acquired Probable cost of the canalization. for the dredging of the Martin Garcia channels. it will be perfectly feasible to attend the canalization of the river Uruguar and to improve it, for which it will be only necessaly to work the dredger dming six months in the rear, which represents an annual expense of $\$ 36.000$ national currency. It might be observed that as the silting may take place suddenly and as its removal by dredging takes some time, the navigation in consequence might be interupted during a loneer or a shorter time after each flow of water.

With respect to such an observation the answer would be, that however suddenly the river falls, this alwats takes place little by little from below to hisher up river: lor instance, when the watel maks yet 2.40 meters at the callue of Concordia the river steamers have not enoush water to pass the "Peruchorerne bar.

But this inconvenience has all the same heen taken into account and in order to eliminate it as far as posible the marking of all the bad bals by alionements on shore, where the coast allows to do so, lias been adopted.

By the aid of those signals which are if posilule, erecterl out of the reach of the highest floods, the channel is absolutely lined out and even in case the buoys. which 
mark its width disappear, the engineers in charge can immediately know to what extent silting up has taken place when the river begin to lower in its superior part, as they are warned of this by direct telegrafic communication. In this way there is the necessary time to remove the partly filling orer a reduced width, to complete this later on over the entire width between the buoys.

It may be assured that three fourth parts of the work to be carried out in sand and gravel will be a permanent improvement and that it will be necessary to maintain the rest, but this maintainance will become less in time because it is believed that the sand is not kept in suspension and only brought down during the great flows of water, and that in consequence the first filling of the chamnels during a high river is therefore due to the steep slopes and great difference of the height of the bottom immediate to the channels eut through the bars.

In short, the improvement of the navigalility of the River Lruguay in the conditions as explained is a work easy to cirry out and of ereat consequence if earlied out with the necessary speed, method and energy.

As the plan of the works are based on studies sufficiently complete for the object in view, and as already dredging works and demareation by signals has been carried out. which so far have given a good result, there is much reason to believe that in the relative short time of two vears, all the obstacles, which now difficult navigation to Concordia, will have disappared, if the approval of the superior (iovernment "an be obtained and if the necessary means can be disposed of.

IVith the surveys realized up to this date it has been partly possible to study the regimen and conditions of the River Lruguay, in order to design the necessary works of improvement for navigation: the part situated between Conrepeion del l'uguray and the River Plate has only been surveyed and studied partly, and this work has been completer by a general recomizance. For this reason those estudies will be continued in this part of the river, which, it may be stated is yet mperfectly known. specially the part between Fray Bontos and Concepeción del Uru- 
guay as is proved by the many errors which the English Chart of this zone contains.

It maly be hoped that by continuing the studies of the River Uruguay in the same manner as at present. that there will be within the time of two rears all that is necesairy for the realization of the present program of works, that a complete chart of the river will be finished. which not only will render great services to navigation, but which will alsoserve as a base for other works for the improvement of the navigation in the Lower [ruguay. which will undoubtedly be neressary after the canalization of the bals of Martín (iareíi has been finished.

I am pleased to be able to state that in the execution of the plans etc., forming part of this study, I have been very ably assisted by the personnel of the Commission and specially by the ${ }^{2}$ Engineer in Chief of this Commission Mr. James Piqazzi, and the assistant encineer's Messrs. Robert Dubosq, Henry Widmüller and Ramon Celinski, who I, for this reason recommend to the consideration of the superiority.

November 1901.

Julio Hexis.

Chief Engineer of the Commission of the Uruguay River. 



\section{A NNEX}

\section{Short description of the studies and works which have been carried out during the years 1902 and 1903.}

\section{MIDDLE URUGUAY}

A precise levelling carried out from Buenos Aires to Concepeión del Uruguay and from there to Concordia has affirmed the approximative results obtained by the studies of the propagation of the tides in the Uruguay Rirer, which showed that the slope at a low river is small and thit the river, even during the montles of extraordinary low water, is navigable as far as the last named port.

In accordance with the proyect for the improvement of the Lruguay River, the dredging of the Sin Francisco Bar,

S.AN FRANCISCO BAR: the first of the many which obstruct the river narigation to Concordia was started.

In this bar, the low part of which is formed by gravel and the upper by sand, a channel has been opened 1011 mts. wide and 2000 unts. long. Alter it had been dredered for the first time, some unimportant siltimg las taken place in its superior part, where the bottom consists of finc sind. which has been removed sinee. It present there are? feet of water at this bar at extraordinary low water, whereals before its dredgine. there were only j feet. 'The formation of the channel through this bar has been completed hy marking it with 2 towers in line on slore, which are lighted during night. and + ordinary buors. 
chapicuy bar. Ifter the dredging of the San Francisco Bar had been finished, that of the Chapicuy bar was undertaken with the object to establish there the same condition of navigability as at the other bars where there is 5 feet of depth at extrandinary low river, whereas at the chapicuy bar there was onlỵ $21 / 2$ feet.

In consequence of the hard material found in the bed of the liver, and as there was no plant at hand to deal it, the channel was lined ont in a curve followine a natural depression in the riverberl.

The result of the dreduing has been that at present resscls of $+1 / 2$ feet dratuht can cross the bar, however low the river may be.

PERUCHOVERNE BAR.

This bar, which is the second of the many met in the Middle Lruguay whre there is less than 9 feet of depth, is artually being dredged.

The material at first extracted by the dredgers was very hard and consisted of ronglomerate of gravel, but his conglomerate was only found over a short distance. The material dredged afterwards is fine sand and gravel.

\section{LOWER URUGUAY}

1)uring the year 1902, , the studies and surveys of the River L'ungay have been extended south of the town of Concepcion det Lruguay and therefore cmbrace that part of the river which is alled Lomer I rmemuly.

Theriver, which between Concordia and Concepción del Uruguay is formed by one single navigable rhammel-with exception ol a lew unimportant arms and islands-has a width varying from 800 to $1500 \mathrm{mts}$. and divides itself bodow the last named town into two arms-one which an be weed by vessels of areat draught and the other by the rivar or (mastwise navigation-which forme a great number of small and large islands. the distance of the shore of the main hand varying from 10 to 12 kilenteters.

Ther only obstatedes loor the ocran navigation, which always follows fhe main arm of the rives, to go as lar as (concep- 
ción del Uruguay were the bars of « \ltos y Bajos, Montaña, Banco frimdes and Roman.

'The dredging works, which have been carried out at the mentioned bars, have given rery satisfactory results: the channels have maintained their depth since the first dredging was carried out and it has only been necessary to make some local corrections and to clean them occisionally.

The "Altos y Bijos and Banco frande balls, which completely prevented navigation and where only existed a depth of 11 or 12 feet at low water, are now (.rossed by at channel where there is always more than 18 leet of water.

The width of the chammel through the "Altos y Bajos» bar is $200 \mathrm{mts}$, and that through the Banco (irande» ball $1.50 \mathrm{mts}$. and of that through the Montana bar $100 \mathrm{mts}$.

The channel through the first two bars is marked by two towers placed in line on shore and which are lighted during night.

The part of the river Uruguay, which is least known. is that situated between the River Gualequarchú and Palmira. In this entire section of the river, there exists only a narrow twisted navigable (-hannel, which almost disappears in what might be called a lake from 8 to 1 2. kilometers wide. The channel is therefore difficult to narigate as well for ocean as lor coastwise ressels.

The channel, though generally deep. is. as already hias been mentioned. full of bends and if not marked by beacons and buogs difficult to narigate.

In this entire zone, the ehannel is enclosed by steep and hard banks or an extensive strand formed by mud, where there is only a depth of one meter. Between those himks the narigation channel passes. Which at some places is only 300 mts. wide, but where depths from 50 to bo feet are found.

Navigation of this part of the river is only possible by using continually the sounding lead, as well during dily time as at night and is generally interrupted at sumset unless the services of an experienced pilot have been secured.

During this month (september 1903) the buoring of the lower Lruguay orer a distance of nearly 100 kilome- 
ters, by means of luminous buoys will be completed and ronsequently navigation will then be as easy at night as by daytime.

In the part of the river under rescription (from the river (fualeg'tuaychí to its mouth) there are only two places in the navioable channcl where the depth is less than 18 feet. They are the «Barrial bar and the «Punta Caballos» bar.

BARRIAI. BAR.

Before arriving at the mouth of the River Gualesuaychu, the narionble chammel disappears to be found again at some distance. Those two parts of the channel are separated by a bar formed by sand and thin mud, to which latter the bar owes its name. At this bar, which must he crossed in ordel to pass from one channel to the other, there is only 13 fect of water at exreptionally low tides. After the surveys lave been concluded, it las been found, that the bar becomes narrow towards the North forming a gorge consisting of sand being only 800 wide. It is at this place that the chamnel to be excarated, for joining up the deep waters, has been projected. The cube to be dredgerl is about 300.000 $\mathrm{N}:$ After this dredging has been carried out the new channel will be marked by luminous buoys, so that vessels will pass safely.

pUNTA Caballos

Alter the last described bar, the only shallow place in B.AR. the River Lrugua till its mouth is the I'unta Caballos » ban. It is situated a little above the mouth of the Rio Negro and is also formed by a long and narrow bar which blocks the naviuable chanuel. The matrial to be dredged is sand. tho quantity to be extracted being only

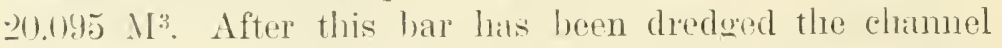
formed will also be marked by luminous buoys.

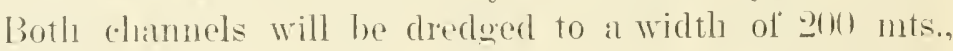
and as the Argentine (iovernment has just made an arrangement with a firm of contractors, to execute this work, it is supposed that before May of next year there will be in thr Rirer Lrmonay from Colon to its mouth the depth as has been established in the project of this Ministry of Pnblice llioks for the improventent of the naviqubility of this river. 


\section{PORTS}

As the intention is to construct for this port, works, CONCORDIA. which will allow the loading and discharging of vessels, whatever may be the state of the river, which yearly differences of water are from 10 to $12 \mathrm{mts}$. and exceptionally as much as $1+\frac{1}{2} \mathrm{mts}$, it is clear that those works will be very expensive. The importance of the sudden rise and fall of the river at this port will be yet better be understood by mentioning the lact, that the river is known to have risen more than jo meters within 24 hours.

The work to be carried out will give the bank of the rivel an uniform paved slope, so that the vessels may be moored against floating pontoons, secured by anchors and which will be able to alter their position according to the height of the river. The pontoons will be connected to shore by means of small bridges.

I project has been made for a wharfing at which riverside steaners and larger coastwise ressels can operate and also for a small basin for the smaller coastwise vessels.

The works will be started within a short time and when finished will contribute much to facilitate the exportation of the products of the many important agricultural colonies, of which Colón is the center.

The minimum deptl at lowest river to reach this port is now 9 feet, but it is intended to increase this depth to 15 feet; the wharf having been proyected so as to allow the deepening of the river to be carried out longside ler.

There will also be constructed a small brick warehouse.

'This port is continually being improved in order to facilitate the operations of ocean vessels.

Besides the wharfing in the main hranch of the River Uruguay, the dredging to widen the entrance channel to the interior port and to deepen it to 11 feet, is in progress. Its depth will be increased in future to 17 feot.

The works carried out in the interior port, which is situated in a branch of the river, as a fuay wall, ralwaly lines, connecting it to the system of the Entre Rios Ry ('o. lave much contributed to increase its inportance and

COXCEPCIÓN DEL LRLGLAY. 
PORT UNZUE NANDUBAYZAL. within a few years it will be necessary to extend those works so as to transform the interior harbour into a very safe port for all class of vessels coming to the port of Concepeión del Uruguay.

When the dredging of the « Barrial» and «Punta Caballos » bal has been carried out it will be accessible under all circumstances for vessels of 19 feet draught.

In the year 1902 the Argentine Congress granted a concession to Mr. Saturnino Unzué for the construction of a port on his property situated on the River Uruguay on the Argentine shore opposite and a little above Fray Bentos. The project consists of a wharfing which provides accomodation as well for ocean - as for coastwise ressels. The island Abrigo in front of the projected works, protects them against southern winds. The natural depth of the river is sufficient for ocean vessels, without requiring dredging. The port will be connected by a railway to the town of Gualegnaychú and with the general Entre Rios Railway system. Though not yet at present, it is intended to construct in future a factory for frozen meat and a grain elevator. The plans for this port are at present at this Ministry for examination and approval.

The port of Gualeguaychi, situated on the river of the same name, is at present, as has been said before only accessible for coastwise vessels of rery small draught. In the year 1902 Congress granted a concession to Engineer sobral for the execution of works to improve it so as make the town accessible for ocean vessels, but till at present no works have been carried out.

As the concession "Sobral " ended in November 190:3, this Ninistery of Public Works has completed now the necessary surveys and studies for the improvement of the entrance chamel and the Gualeguaychi river, and Congress having granted $\$ 100.000$ gold for the works, the town of Crualeguachil will soon be accessible at lowest river for coastwise vessels of 7 feet of draught. 
St. LOUIS EXHIBITION (UNITED STATES OF N. AMERICA)

工

\section{EXPLANATORY INDEX}

OF THE

\section{OBJECTS EXHIBITED}

BY THE

\section{MINISTERY OF PUBLIC WORKS \\ $\mathrm{OF}$}

ARGENTINE REPLBLIC

DIRECTION GENERAL OF HYDRAULIC WORKS

MILITARY PORT OF BAHIA BLANCA * * *

DEPARTMENT OF ENGINEERS OF TLCUMAN * 



\section{$\mathrm{NOTE}$}

The objects exhibited by the Ministery of Public Works of the Argentine Republic and presented by the Direction General of Hydraulic Works, have been divided into five groups:

$$
\begin{aligned}
& \text { I. - River Plite. } \\
& \text { II. - River Paliní. } \\
& \text { III. - River Uruguiy. }
\end{aligned}
$$

IV. - Militart Polit of Bahia Blayca.

V. - Masontr Dam and Reserveir for the Irrigation Works of the Province of Tucumáx. 



\section{Direction General of Hydraulic Works}

\section{I. - RIVER PLATE}

This great plan executed in relief to the scale of 1:40.000, and covering an approximate area of 3500 sruare kilometers, shows clearly all the particulars of the bed of the Upper River Plate. With its aid the numerons cliannels and banks that exist and also the great number of rivers that form the Paraná Delta, as well as the situation of the luminous and other buoys and signals destined to facilitate navigation, can easily be seen.

This plan also shows the Ports of Buenos Aires and La Plata, with their entrance channels. buoys and beacons, by means of which the aecess to them is facilitated.

Six maps have been put up in album form: the follo- 2. Асвем wттн wing is a short description of them:

After having finished the survey of the Upper part of the River Plate the navigable channels have been buoyed. This is one of the most important works carried out. The buoys indicate precisely the route to follow, aroiding, by doing so, the groundings that were formerly so frequent, and that caused so much detriment to the general commeree.

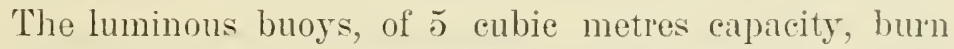
night and day, the greater part of them being supplied with mineral oil gas and the rest with acetylene gas. The gas is taken to the buoys by steamers provided with storeholders which are loaded with gas from a gas factory: both the steamers and gas works were specially constructed for this purpose on the Pintsch Patent Lighting system.

This plan is a resumé of the results of the survey carried Nap. No 2.-Geneout by the staff of the Ministry of Publie Works of the $\begin{gathered}\text { ral Map of th } \\ \text { River Plate. }\end{gathered}$

PI.A. IN RELIEF River Plate. MAPS OF TIIE River Plate. Ylan No 1.-General Mapi of the luminous bunying of the River Plate - Scale 1.20000, lear 1902. 
Nation up to 1908, and embraces the upper part of the River Plate.

This survey has been carried out with great care by means of a great number of soundings and eross sections, and close observation of tides. An excellent triangulation covers completely the studied zone. This plan also contains the position of all the signals for navigation that exist on the River.

Map No 3. - Lruguayan shore of the Upper River Plate.

Nap No 4.- Outer Roads of Buenos Aires. Year 1903

Map No 5. - Farallon $\mathrm{B}$ ar, Scale $\mathrm{I}: 40000$.

ap No 6. - New Channel, scale I: 100000 , Year 1903.

MOUEL OF THF Gravisg Dock OF THE PORT of Buenos MIKES.

The problem of the interior navigation of the Parani- and Uruguay Rivers being based on the navigability of the channels near the Uruguayan shore of the Upper River Plate, this map has therefore been prepared on a large scale which allows it to be perfectly studied, there being an abundance of details.

This map, drawn to the seale of 1:40000, embraces the part of the River Plate in front of the City of Buenos Aires, including its Port, the access channels, and the manner in which the latter have been marked with buoys and beacons.

This map embraces with many details the zone of the River Plate where there is less depth in the route of navigation of ocean vessels. All the buoys and the position of all rocks that may be dangerous to navigation in the proximity of the Farallon (Colonia Lighthouse) are indicated.

This channel was buoyed for the first time in the year 1892, the passing of vessels and the elfects of the current have produced a natural excavation of 3 feet. This channel has at present 1!) feet at low water, and the luminous buoys greatly facilitate its navigation.

The port of Buenos Aires has two graving dorks, one 180 meters and the other 150 meters long. This model represents with all details the largest of the two to a sale of $1: 100$. It shows the eulverts for emptying the dock, the engine house, the floating aisson and all details of its construction.

4. Luminous Bury. ing of the $\mathrm{F} n$. trance Channels to the Port of Bueno; Aires.

'This plan inclicates in detail all the signats, luminous - and other buoys and beacons that mark the access channels to the l'ort of Buenos Aires, the position of the Semaphore and the form of signals most commonly used for the buoring. 
This album is a collection of photos of the various ty- Photographatbun pes of dredgers, the tug boats, and other craft belonging to this Ministry. There are also some photos of important works executed and in execution, that give an ample idca of the forward state and progress of public works in the Argentine Republic. Annexed to the album there is an index of the photos it contains.

This is the last plan prepared by the Ministry of Public Works of the Port of Buenos Aires in its present state. It shows the general disposition of the Port, and contains also the channels, the Riachuelo Port. Southern Dock, etc. On both sides of the Riachuelo there exist good timber wharfs that allow of ocean and coasting steamers being moored to them. On the Southern shore of this river 1200 meters of wharfing are now under construction.

Where the South Entrance Channel commences the Ministry of Public Works has its workshops, where the repairs to the dredgers and other craft are carried out. In the North Basin are installed the graving docks and workshops which belong to the administration of the Miinistry of Marine.

To give an exact idea of the importance of the Port of 7 . Panorama of the Buenos Aires, three Panoramas taken from different places Aires are also exhibited. They show the traffic of ocean steamers and coasting craft.

This album contains photos of the steamers and other 8. Photos of Vessels vessels for all the different serrices of the Ministry. At the belonging to the Ministry. end of this description there is an index of all the craft.

\section{RIVER PARANÁ}

The importance of the studies of the Paraná River in front of the City of Rosario (on the occasion of competitive tenders for the construction of its Port being called for) - Plan in relief of the River Paraná in front of Rosi. has motived the preparation of this plan. It shows the curves for every meter difference in depth of the bed of the river, and ist general formation, as well as its other peculiarities, such as banks, channels, ete. 
2. Plan in relief of the River Para. ná in front of ná, Scale I:I0000.

Portfolio of Maps of the 1.o. waná.
This plan was eonstructed, as was the preceding, with the object of showing in a plastic form the results of the surveys wich were carried out to serve as a basis for a project for a Port for the City of Paraná. For its construction the same method was followed as for that of Rosario, the curves of depths show the differences from meter to meter and embrace all the zone that was studied in order to select the bestlocation for the future port.

The entire course of the River Paraná to its mouth in the River Plate has been divided into three sections named respectively Upper-, Niddle-and Lower Paraná. The first section embraces the part of the river between Corrientes and Santa Fé; the second that between Santa Fé and Rosario, and the third that between Rosario and the mouth of the Guazú: the approximate lengths of these sections are 508,160 , and 420 kilometres respectively.

The aforementioned portfolio contains in 16 sheets the map of this section of the River to a scale of $1: 20,000$.

Rosario-River Plate; One index sheet to the scale of 1:100000. This plan indicates the relative position of the different sheets which constitute the total survey.

This survey is based on a triangulation which takes in the two shores, the vertices are used as reference points to fix the profiles of the soundings. These have been carried out at variable distances, from a maximum of 200 metres at points where great deptlis are fomd and navigation is easy, to a minimum distance of 20 metres in the parts where there is little depth, and where, therefore, the soundings for each section are numerous and most closely taken in the most interesting parts; the position of each sounding is referred to red signals on shore. The constant observations at two alutomatic registering gauges erecter in Rosario and Sin Pedro, and at ten ordinary permanent galuges placed at different points of the river during the execution of the survey, gave the necessary olements to reduce the heights of water observed to the hydraulic zeros. Besides these permanent gallyes, tempority gauges were also erected and continuously observed at the most important points, as at the bars and shoals, during the time they were surveyed.

The maps in the portlolio have been eompiled lrom these 
surveys. The bed of the river is shown by eurves of depths taken at distances of one meter. The list of all the maps contained in this portfolio, with the details of each, is given in the Appendix.

This contains 8 sheets on a scale of $1: 20,000$ and one index sheet on a scale of $1: 1,000,000$. It embraces the course of the River Paraná between Rosario and Santa Fé over an extension of 160 kilometres. The have been compiled from the surveys in the same manner as those of the Lower Paraná. The list of all the maps contained in this portfolio is given in the Appendix.

On this plan are shown all the constructive data which have relation to the works designed for the Port of the town of Rosario, which work is now in execution. The centre part of the plan shows the general plan, the works for the correction of the river, dredging and quay walls and wharfings, sheds, warehouses, etc. and round it are artistically grouped plans and sections of the more important works as masonry and timber quay walls, concrete walls, and drawings representing the type of the dredging plant used.

The photographs contained in this album show the most important points of the river and also the works which have been carried out. A detailed index of all the photos is given at the end of this booklet.

\section{RIVER URUGUAY}

The port of Concepción del Uruguay, situated at a dis- 1. Plan in relief of tance of $18+$ kilometres from the mouth of this river, is the last port that can be reached by ocean-going ressels. the port of Con-

guay: Scale 15000. Besictes having a basin for the coasting vessels in the smaller arm of the river, access to which is given by an artificial access channel with its entrance protected by a stone dam, there exists also in the principal arm of the river a great mole for the ocean-going vessels.

The plan shows these installations and the peculiarities of the river bed at this point.

At Concepción del Urugutay is installed the Commission 
for the Study of the River Uruguay under the direction of the Direction General of Hydraulic Works.

2. Portfolio of Naps of the R ver Uruguay.

Portfolio of the Plans show ing the studies of the River Lruguay.

Descriptive Me moir.

5. Album with Tho. tographs
The 21 maps which this portfolio contains are of an exploration of the Upper River Uruguay ( from Concordia to Santo Tomé), of the survey of the Middle Lruguay ( from Concordia to Coneepcion ), and of the survey of the Lower Uruguay firom Concepeión to its mouth.

Besides these maps there are others with details of the parts that are difficult to navigate; they are drawn to a scale of $1: 10.000$ and show the improvements and the buoying that has been projected or executed.

A detailed list of these maps is given at the end of the booklet.

This portfolio eontains 15 sheets showing the most important hydraulic features of the River Uruguay, such as instantaneous sections, studies of the tides and slopes, graphic demonstrations of hydrometric observations, and studies of the flow of water and velocities at different places, etc.

In the corresponding Appendix details of these plans are given.

For the benefit of all who take an interest in the studies, surveys and works that have been carried out in the River Uruguay, a descriptive memoir has been prepared, which deals with the studies and projects for the improvement of this river:

This album, like those above mentioned, contains views of the different points of the river, of the works, dredgers, steamer's and other craft at the disposal of the Commission, signal for navigation, etc. Details of these photos will be found in the last appendix of this booklet.

\section{IV. - THE MILITARY PORT OF BAHIA BLANCA}

I. Plan of the Istuary of Bsalic Blanca.
This plan shows the topography and hiclrograplry of the estuary of Bahia Blanca, and the relative position of the Military Port, located in Punta Alta: of the commercial lort belonging to the Ferro Carril del sud (Sonthern R.R.) lowated near the Arroyo Napostá; of the commereial Port of the Ferro Carril Bahia Blanca y Nor-Oeste (Bahia Blanca 
and North IVestern Railway) located near the Arroyo (ralvan. More inside of the estuary there is another pier for the chilled beef lactory at Cuatreros.

This plan shows with blue colour - of deepen hue in proportion with the depth of the water - that in the estuary there are not less than $322^{\prime}$ of water for all its length from the Atlantic up to Punta Alta in here is located the Military Port: and that in the anchorage of " P'uerto Belgrano» opposite the Military Port, can ride safely at anchor the largest fleet.

From the anchorage there is a channel about $2000 \mathrm{~m}$. in length, dredged (for the present) to 21 feet at low tide and 32 feet at high ordinary tide, which allows the largest men of war to pass from the anchorage to the tidal basin of the Military Port. There is also another chamnel dredged to $18^{\prime}$ at low tide and 29' feet at high tide which allows commercial ships to follow the estuary up to the commercial Port of the Southern Railway opposite Bahia Blanca. This plan contains all the works in project - even those 2. Plan of the Nafor a far away future - and the works that at present are sufficient for the Argentine Navy.

These works - in their majority already finished consist of :

a) An outer harbour which protects the tidal basin from the waves of the estuary.

b) Of a tidal basin for large men of war, dredged to 30 feet at low tide and with 41 feet at ordinary ligh water.

c) Of a granite dry dock, - the largest of America in which any ship of war or merchant can be docked - the «Baltic» can enter this drydock and the «Iowa» was docked here.

d) Of a quay wall $250 \mathrm{~m}$. long and 30 feet deep at low water, provided with hydraulic cranes, one of which of 30 tons power.

This quay wall is not yet finished but will be by the micldle of 1904 .

Round the tidal basin there are workshops for the repairs to ships, deposits for armaments, ete. There are also 
houses for employees, barracks, and is also ready the first section of the Naval Hospital with 80 beds and in position of receiving 400 in case of war.

The Nival Station is provided with waterworks, sewarage, electric ligth, and usual installations for the service of a dockyard.

Also a small town has almost sprung up round the dockyard in here in 1898 there was a complete desert.

This plan shows the principal dimensions and details of

ving Dock and anexed tidal $\mathrm{B}$ a$\sin$

4. Normal sections of the principal works. the dry dock, $222 \mathrm{~m}$. long, $27 \mathrm{~m}$. wide at the entrance and $10 \mathrm{~m}$. deep on the eill, at ordinary high tides.

This plan shows the system of construction of the dry dock, built entirely of concrete made of portland cement, sand and gravel, with a ficing of granite so that the general aspect of the dry dock is as if it were built entirely of granite. Thus it combines the durability of granite with a moderate expense and rapidity of construction.

The dry dock can be pumped out in $21 / 2$ hours by means of two large centrifugal pumps, driven each one by a 400 H.P. compound engine; the dock is also provided with hydraulic capstans and cranes, electric light, water mains, railway service, etc. The entrance is closed by a sliding caissoon removed by hydraulic power in 3 minutes. There is also an intermediate floating caisson for the internal divisions or for the porpose of leaving dry the sliding caissoon when this needs paiting.

This plan shows the general outlines and dimensions of the most important works, that is:

a) Entrance channel, dredged with $80 \mathrm{~m}$. width at the bottom, and depth of $32^{\prime}$ at $\mathrm{O}$. H. $\mathbb{W}$. and $21^{\prime}$ at O. L. II.

b) Pumping-engine house and sliding caissoon with its recess.

c) Diagram showing the dimensions of the largest ressels afloat in comparison with the dimensions of the graving dock.

d) System of construction of the graving dock, in its various periods.

e) Details of the sliding caissoon at the entrance of the diry dock. 
This plan shows the arrangement of the quay wall ane- 5. Quay Wall. xed to the graving dock, the normal section of this quay wall, and the arrangenents of its various parts, that is:

( ) Hydraulic movable cranes of the elevated type, with its adjoining sheds for temporary deposit of goods, armaments, etc., to be transhipped.

b) 30 tons - hydraulic crane with derricking jib, with railing sidings for laandling large guns or bulky weights.

c) Coal elevators for unloading about 100 tons of coal per hour from the colliers to on land, or for deposits, loading 120 tons of coal per hour to the war vessels, or to barges, or railway trucks, including screening and weighing.

These albums contain a collection of the most impor- 6. Two albunswith tant plans of the Naval Station. Lighthouses, Semaphores, and other works. The collection consists of 120 sheets of $0.65 \times 1.20 \mathrm{mts}$, showing general plans, studies, entrance channel, graving dock, engine house and engines, sliding eaissons, hydraulic pressure mains, cranes, tidal basin, quay wall, water supply, building for the storage tank, sewers. buildine, and various other designs.

All these plans are mentioned in detail in the last Appendix.

This album consists of a collection of 62 views of the $\mathrm{Mi}$ litary Port, all of which are detailed in the appendix to I'hotograph Al. lium. this booklet, and which show the state of the works. and how they are used for war ressels.

\section{MASONRY DAM AND RESERVOIR For the Irrigation Works of the Province of Tucumán}

The Department of Public Works \& Irrigation of the I. Plan in relief Province of Tucumán has designed a grreat natural storage reservoir of a capacity of $200,000,000$ cubic metres of water, of the Masonry Wall and Depo. sit of Cadilial. destined for the irrigation works of this province. The cost of this work has been estimated at orer one million of $\mathrm{Ar}$ - 
gentine currency. The plan shows the general disposition of the works and the artificial lake.

The author of the design is the Director of the Iepartment of Public Works of the Province, Mr. Charles Wauters, Civil Engineer.

Plan in relief This plan shows on a larger scale than the former one,

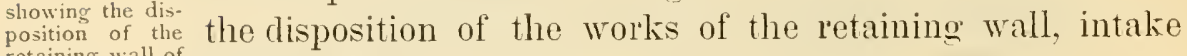
retaining wall of the Reservoir of overflow, ete.

Cadillal. 


\section{INDEX}

of the plans, maps \& photographs contained in the different portfolios \& albums

\section{0 - River Paraná}

This contains the following photos of the Port of Buenos Photograh Albur. Aires:

1. General view of the Workshops of the Ministry of Public Works in April 1899.

‥ Ditto. ditto. in October 1903.

3. Ditto. ditto. with a view of the Entrance Channel, 1903.

4. Ditto. ditto. from the signal of the South Channel, 1902 .

5. Ditto. ditto. in December 1902.

6. Slip belonging to the Ministry of Public Works in July 189.9 .

7. Ditto.

ditto.

in January 1900.

8. Ditto.

ditto. (two views) in 1900.

9. Workshops and protecting moles of the South Entrance Channel.

10. Workshops of the Ministry and Offices of the Direction.

11. Framework of the original Workshops, 1897.

12. Compound Engine of the Workshops. July, 1899.

13. Turning and fitting shops, August 1908.

14. Ditto.

ditto.

15. Small lathes and planing engine, 1898 .

16. Dynamos for light and power, September 1903.

17. Large Compound Engine of the II'orkshops.

18. Small ditto. ditto. 
19. Carpenter's shop, Angust 1903.

20. Ditto.

December 1902.

21. Bandsaw constructed in the Workshops, 1901.

22. Punching \& Cutting Engine and planing engine for wood.

23. Big lathe, 1900.

24. Small steam hammer, 1900.

25. Smith's shop, 1903.

26. Boilermaker's shop, 1902.

27. Ditto 1903.

28. Smith's Shop, 1902.

29. Foundry, 1909 .

30. Ditto. with cupola, 1902.

31. Gasworks with gas buoys readly to be erected.

32. Ditto. South front.

33. Ditto. Accumulators, water-tank, and gasometer.

34. Luminous buoys.

3.. Gasworks. Wharfing and cranes for handling the buoys.

36. Luminous buoys.

37. Gasworks - Compressors.

38. Ditto. - Boilers.

39. Ditto. - Purifiers.

40. Ditto. - Furnaces.

4. Water-tank and filter.

4. Semaphore and house of the and. Chief.

4\%. Refonleur (Mud pump).

4t. Low grounds in the port works being filled by the refonleur.

t5. The dredged material filling the low grounds.

4h. Low grounds after having been filled.

47. Entrance of the South Channel-- Protecting mole.

4. Ditto. ditto. ditto.

49 \& 50 . Views of the protecting mole.

j). Entrance mole of the Port.

5.). Reconstruction of the Riachuelo wharfing.

53. Ditto. ditto. ditto.

5t. Ditto. and Riachuelo Port.

5.). Ditto.

itt. Riachuelo port. 
57. , Hitto.

59. View of the Arant-Port.

(6). Ditto.

b1. Dock Sud ( South Dock).

62. I I Iitto.

64. Avint-port and Riachuelo.

65. Ditto.

66. Slipways of the Ministry of Public Works.

67 \& 68. Dock No. 3.

69 \& 60 . (irain Elevators.

71. Hydrographic Office at the North Basin.

7.9. Graving Dock.

73. Bridge over the Riachuelo.

74. Engine House.

$75 \& 76$. Vessels undergoing repairs.

77. Birdseye view of the Workshops of the Port of Buenos Aires.

78. Guter mole of the South Dock.

79. Entrance to the Moles of La Plata.

80. Central Doek (La Plata).

81. Ditto. ditto.

82. Naval station at La Plata.

1. Barge for the transport of materials.

2. I)itto. Floating pile driver.

3. Floating shearlegs and barge for the transport of dredged material.

4. Barge witl piledriver, and ditto. for the dredged material.

5. Barges for the transport of dredged material.

¿. Houseboats for surveying purposes.

9. Houseboat and Floating Semaphore.

10. Floating Semaphore.

11. I Ditto. ditto. and steam liunch for a sur-

12. f reving party. 
13. Ditto.

$1+\& 15$.

16.

17. Steam launch for surveying purposes.
18.

19. I Steam launch for surveying purposes.

22. Steamers for surveying purposes.

28.

24. Steamer for inspecting and loading the gasbuoys. 25.

26.

27.

28. Tugs.

29.

30 \&31. Barges for dredged material.

32. Barge, dwellinghousse and office for surveying purposes.

$33 \& 34$.

35.

36. Barges for dredged material.

38.

39.

$40 s+1$.

42.

43.

44. Dredgers.

4.5.

$4 t$.

47.

48. Dredger and Refouleur ( Mud-pump).

49. Excavater and Refouleur.

50. Barge with boring apparatus and clitto. with steam pump.

51. Floating crame and Refouleur ( Mud-pump).

5.). Dredger. 


\section{1. - River Paraná}

Lower Parixi. - Index sheet and sheets 1 to 1 o.

Index sheets showing the division of maps from Rosario Portfolio with to the mouth of the Guazui.

1. City of Rosario and neighbourhood.

2. Alvear and Paraguayo Bars.

3. Villa Constitución and neighbourhood.

4. San Nicolás and neighbourhood.

ว. Tonelero and Las Helmanas Bars.

6. Obligado and neighbourhood.

7. San Pedro and neighbourhood.

8. From San Pedro to the Isla Grande (Creat Island).

9. Mouth of the Paraní de las Palmas and neighbourhood.

10. Island of the Bizcaino, Ibicuy River, Zanja Mereadal and upper mouth of the Talavera.

11. Island of the Botija and lower mouth of the Tatlavera.

19. From Dorado Island to «El Ceibo».

13. Portuguez Bar and neighbourhood.

14. River Bravo and its mouth.

15. Mouth of the Guazú and of the Bravo.

Midde Parand. - Index sheet and sheets 1 to $S$.

1. City of Paraná and neighbourhood.

2. City of Santa Fé, river of the same name, and part of the River Parana as far as the Tragadero Bar.

3. From the Paracao Bar to the Arana Islands.

4. From the Arana Island to the Taemani.

๖. From the Tacuani to the Reyes.

6. From the mouth of the Reyes to the Island of Los Pajaros.

7. From the Island of Los Pajaros to the mouth of the Bobo.

8. From San Martín to Alberdi.

'This album contains the following views: 
Page 1. Port of Zárate.

2. Rosario, View of the town and the national wharfing.

》 $3 \& 4$ Rosario, Anchorage.

》5. Dredging plant at the Paracao Bar.

» 6. Sparbuoys at the Paciencia Bar, Buoys and gridance signals at the Paracao Bar.

7. Bajadia Grande. General view of the wharfing.

8. Paraná - Salto del Calderón.

9. Paraná - Anchorage.

10. Puerto Viejo (Old port).

11. Paraná - Birdseye view from the Morro.

12. Paraná - Limekiln and Panorama.

13. Santa Fé - Views of the town and wharfing.

14. Santa Fé - Installations of the surveying commission and the cut of the Paraguayo.

15. Colastiné -- Port and deposit of hardwood logs.

16. Colastine - View of the port.

17. Moutly of the Piragua and Slaughterhouse Santa Elena.

18. La Paz (Curtiembre) - View of Esquina.

19. Tiew of Esquina.

20. Port of Reconquista - Wharfing at Goya.

21. Bella Vista.

22. San Antonio. Pilcomayo.

23. Port of Asunción (Capital of the Republic of Paraguay ).

2. Anchorage.

2.5. Corrientes, view of to Mole and Govermment House.

26. Views of the town of Corrientes.

27. Island of rocks below Itatí.

28. Views of Itatí.

29. Church of Itatí, Group of Palmas indians.

30. Views of Humaití and neighbourhood.

31. Humaitá.

3:2. Villa f'ilatl. Island de Aquino.

33. Views of formosa.

34. Villat Fance. Sub-prefecture of Formosa. 
Page 35. \& 36. Views of Formosa.

»37. Cillardia Angostura near V'illeta. Villeta.

$\gg$ 38. Lambaré Hill -- Empedrado.

39. Colonia Lrquiza. - ( La Curtiembre) ( Tannery ).

» 40. Zanja Mercadal.

\section{$2^{\circ}$-- River Uruguay}

The 23 maps it contains are in detail the following:

Portfolio of Maps.

Sheet 1. Exploration of the Upper Uruguay from Concordia to Santo Tomé.

Sheets 2. 3 \& 4. General maps of the Mirdde Lruguily showing in conjunction the peculiarities of the river bed and the relative position of the principal points.

Sheets 5, 6 \& 7 . Maps of the lower course of the river, giving a topography entirely different to the other parts.

Sheets A \& A'. Detail plans of the bars of Corralito and Yuqueri, which are situated immediately below the port of Corcordia. The first of these bars is full of rocks.

Sheet B. Map of the Vuelta (curve) of Dayman: this part of the river is very regular and easy to navigate.

Sheets C \& C'. Hervidero Bar. This is a tortuous passage between rocks. Its rectification to a depth of 9 feet lias been projected.

sheet D Chapicuy Bar; the most difficult bar, and the one which is the greatest obstacle to the access to the port of Concordia; it lias been surveyed with great care in order to design its canalization.

Sheets E. F. \& (. . H. \& I. Maps of the Bars of Cillavivú, Sombrerito, San José, Cancha Seca, and Pepe Ají : these bars are formed by sand and gravel.

Sheet J. Peruchoverne Bar, the last of the many which exist between Concordia and Colón. 
Sheet K. San Francisco Bar. This bar was deepened to 9 feet over a width of 100 metres in order to facilitate the access to the Port of Colón.

Sheet L. Plan of the Port of Paysandú, which town is situa ted in the Republic of Unngray. Thongh there is plenty of depth in the port itself, its accoss is made diffienlt by the existence of the Almiron Bar, 9 kilometers down river.

Sheet M. Almiron Bar with a minimum depth of 10 feet. The execution of the works for improving this bar is left to the Uruguayan Government.

Sheet N. Map of the anchorage and port of Concepción del Urugnay.

Portfolio with Plans of the Stur dies.
Sheet 1. Instantaneous sections of the tidal wave, which show the manner in which the surface of the River Uruguay is affected by the tides of the Atlantic Ocean, which are transmitted over a distance of 293 kilometers from the mouth of the river during the periods of a low river.

Shect 2. Graphic demonstration of the tidal wave, showing the form of the wave for an ordinary and an extraordinary tide.

Sheet 3. Longitudinal section of the surfice of the river Urugnay below Concordia, showing the slopes of the river at its different heights of water.

Sheet 4. Graphic demonstration of the relation of the zeros of the water-gange, which have been levelled by studying the tides as there was no precise levelling, which is now being carried out.

Sheets 5 to 9. (iraphic demonstration of the observations at the gauges at Nueva Palmira, Fray Bentos, Concepción del Uruguay, Nueva Escocia, Concordia, and Paso de los Libres.

Sheets 10 \& 11. Diagrams of the winds and rainfall registered during the years 1900 and 1901 at Concepción del Uruguay.

Sheet 13. Diagram representing the variation of the flow and relocity for the different states of the river at Concepción del Uruguay and Nueva liscocia, as 
well as the corresponding different lieights of water at Concepeión del Uruguay and Concordia.

Sheets 14 \& 15 . Sections of velocities at Concepución del Uruguay and Nueva Escocia tor different leights of water and conditions of currents.

Pages 1 \& 2 . Types of the signals indicating' the centre of Photograph Album the dredged channel in the bars Banco Grande and Altos y Bajos. 'They carry lights during the night and a gauge which indicates the minimum depth in the dredged channel.

$3 \mathrm{~d} 4$. Views of the mole for ocean traflic at Concepción del Uruguay when the river is rery hiwh.

» 5. The mole of Concepcion del Lruguay as seen from up river.

$\gg 6,7 \& 8$. Tessels being worked at the mole of Concepción del L'ruguay.

»9. Access from the shore to the mole of Concepreion del L'ruguay, showing the hut for the automatic tide-gauge on the right hand side, and that of the watriman on the left.

10. The same access at a high flood.

$\gg 11 \& 12$. The bridge giving access to the mole during a high flood.

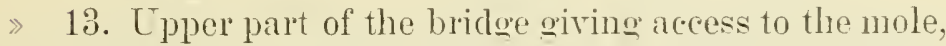
with Custom House and «Sub Prefectura» (harbour police ).

»14. Entrance to the access channel for the inner Port for coasting vessels at Concepción del L'uguay.

$\gg 15$ \& 16 . Tiews of the abore-mentioned entrance channel.

» 17 \& 18 . Dredgers for the excavation of the entrance channel.

》 $19 \& 20$. Dredgers operating in the inner port for coasting ressels of Concepción del L'moruar.

$» 21 \& 22$. Slip of the Ministry of Public Works at Concepción del Lruguay.

$\gg 28$ \& 24 . Works for improving and extending the slipways at Conecpoión del Uruguay.

» 2อั. Dredgers working in the River Uruguay. 
Page 26. Bivouac of engineers on a survey.

» $2 \bar{\tau}$. Offices of the Commission for Surveys and Works of the River Uruguay, at Concepción del Uruguay.

».8. Workshops of the Ministry of Public Works at Concepción del Uruguay.

»29. View of the port of Colón in its presents state.

»30. View of the port of Concordia in its present state.

》31. View of the port of Concordia, with a high river.

»32. View of one of the nunnerous rapids of the River Uruguay.

\section{0 - MILITARY PORT AT BAHIA BLANCA \\ General Plans \& Various Studies}

1. General plan of the works for the defense of the Atlantic coast of the Argentine Republic. Scale 1: 2.500.000.

2. Hydrographic plan of the Port of Belgrano at Bahia Blanca (general plan of the works) Scale 1: 150.000.

3. Hydrographic plan of Puerto Belgrano and soundings. Scale 1: 40.000.

4. Hydrographie plan of Puerto Belgrano. Pits and borings. Scale 1: 40.000.

5. Hydrographic plan of Puerto Belgrano. Scale 1: 40.000.

6. Topographic-hydrographic-geognostic-in hirdrognostic plan of the neighbourliood of Punta Alta at Puerto Belorano. Scale 1:, 5000 .

7. Cross sections A. B' (with reference to the plan mentioned above)

8. Ditto. A. B' ( Ditto. Ditto. )

9. Ditto. C. C" ( Ditto. Ditto. )

10. Longitudinal sections

$$
\text { X. Y. ( Ditto. Ditto. ) }
$$

11. Jitto. W. S. ( Ditto. Ditto. )

12. Hidrognostic studies in the neighbourhood of Puerto Belorano (sections).

13. Sources of studies for the Entrance Channel.

14. Plan of the Naval Arsonal reduced to the works neressary for the immediate future. Scale 1: 2500. 
15. Plan of the Naval Station which will in the future be transformed into a Naval Arsenal, (most urgent works), Scale 1: 2500 .

15. General constructive plan of the Naval Station Scale $1: 2500$.

17. General plan of the Naval Station. Seale 1: 2000.

ENTRANCE CIIANNEl,

18. General plan of the soundings in the entrance channel and the Avant-Port. Scale 1: 2000.

19. Various buoys for mooring and other purposes.

20. Beacon.

\section{GRAVING DOCK}

21. Graving Dock-Plan and Sections. Seale 1: 200.

22. Ditto. Disposition of the layers of concrete in the bottom and side walls. Scale 1: 50 .

\section{Engine House \& Engines}

23. Frontage towards the Avant-Port. Scale 1: 50.

24. Frontage and sides of the Boiler House. Scale 1: 50.

25. Plan and sections of the walls. Scale 150.

26. Plan showing the installation of the centrifugal pumps. Scale 1: 100 .

27. Details of the installation of the main-and leakage pumps. Scale $2: 20$.

28. Details of the engines of the main pumps. Scale $1: 10$.

29. Details of the centrifugal pumps. Seale 1: 10.

30. Details of the sluices of the drainage culvert. Scale. $1: 10$.

31. Details of the boilers. Scale 1: 10 .

32. Acumulator tower. Scala 1: 20.

33. Plan showing the complete arrangement of the hydraulic machinery and accumulator. Seale 1: 20 .

34. Details of the hydraulic pressure machinery.

35. Details of the accumulator. 


\section{Sliding Caisson}

36. Sliding caisson with lifting bridge and hydraulic action, with corresponding diagram (general plan).

37. Sliding Caisson - Plans and section (working drawings).

38. Sliding Caisson-Longitudinal section and cross sections.

39. Sliding Caisson-Hydraulic machinery for working same.

40. Floating Caisson-(general plan).

41. Ditto. -Longitudinal- and end views.

42. Ditto. - Longitudinal-and cross sections.

43. Ditto. - Various plans.

(Sheets 41,42 \& 43 are working drawings)

\section{Hydraulic Piping, Cranes, etc.}

4t. Arrangement of the cranes, hydraulic piping, roads, etc., belonging to the quay wall.

4.5. General plan of the pressure- and return mains, and the water supply for the graving dock.

46. Fixed crane of 30 tons.

47. Noveable crane of $j$ tons.

48. Ditto. of $1 \frac{1 \%}{2}$ tons.

49. Hydraulic eapstan of 5 and 10 tons.

50. Ditto. ditto. of 1 tons.

\section{Tidal Basin}

51. State of the dredging on 31st. August 1903. Scale $1: 1000$.

52. Details of the slopes, larders, mooring posts, buoys, etc.

\section{Quay Wall}

5. Construction of the cofferdam marle for the purpose of building the quay wall in the dry.

55. Plans, elevations, and sections. 
56. Ashlar, bollards mooring posts, rings, etc.

57. Piping, posts, bollards, and other metallic accessories.

58. Normal- and other sections of the quay wall.

59. Subway for the service pipes.

60. Discharge pipes for the sewer's.

61. Plan of ensemble of the quay wall with cranes, elerators for coal, etc.

\section{Derivation of the Water Supply from the River «Sauce Grande »}

62. Catastral plan of Bahía Blanca, scale $1: 200,000$.

63. General plans and longitudinal sections.

64. General plan of the piping (1st. section).

65. Ditto ditto (2nd. section).

66. Ditto ditto (3rd. section).

67. Ditto ditto (th. section).

68. Longitudinal section of the ramification to P'uerto Militar and to the village Puerto Belgrano.

69. Longitudinal section from the origin to the town of Bahía Blanea.

\section{Deposit and Sources of the Water service}

70. Elevation and plan of the tank for the water service, telephone station, etc., scale $1: 50$.

71. Details of the construction of the watchtower, scale $1: 20$.

72. Intake culvert for the water service, and other works, such as pits in the district of the Military Port, scale $1: 5000$.

73. Sources of the water in the downs of the Magnetic Observatory.

74. Distributing pipes for the water service in the rarious districts of the Military Port.

75. Engine house for the water service. 


\section{Sewers}

76. Plan and section, scale $1: 100$.

77. Various sections and registering outlet $(1: 20)$.

78. Regulating chamber, scale $1: 20$.

79. Details of the regulating chamber and discharge chamber.

80. Detail of the outlet into the sea, scale 1:20.

81. Plans and sections.

8. Details of the regulating chamber.

83. Details of the registering outlet, etc.

(Sheets 69,70 \& 71 show how the sewers were constructed and contain the modifications that were introduced during eonstruction.

\section{Various Buildings}

8t. Hospital for the Navy. Plan of a pavillion.

85. Ditto Kitchen, Wash-house, and other out-

S6. Ditto

Ditto

Ditto.

(houses.

87. Iitto Cellar of the out-house to pavillion $\mathrm{N}^{\circ} 3$.

88. Hospital - Sidewall (misonry works).

89. Dwellinghouse for the Medical Director of the Hospital.

90. Chalet $\mathrm{N}^{\mathrm{o}} 8$.

91. Chalet No 8 bis.

9.. Offices, and other buildings.

93. Wwelling-house $N^{\circ} 23$ for employees.

14. Ditto No 24 Ditto.

\%). Post and Telegraph office. Elevation and sections.

96. Ditto Ditto Plans and details.

97. Principal entrance to the Naval Arsenal.

!R. School «Humberto I», erecter by public subseription.

919. Marnetic office of the Military Port.

100. Cemetery, crematorim, otc.

101. Barracks for the Coust Artillery-General plan.

102. Ditto Ditto. Elevation and sections.

103. Powrder House - elevation, plan and sections.

104. Ditto details of walls and windows. 
105. Powder House - various details.

106. Ammunition stores.

107. Dwellinghouses for the officials of the powder louse and ammunition stores.

\section{VARIOUS DESIGNS}

108. Moorings for ocean-going vessels in tho River Sinta Cruz (transformable into graving dock).

109. Naval Station in the River Santa Cruz.

110. Telegraph line to the South Coast (Ist. section).

111. Ditto. (2) (2ndto. section).

112. Ditto. Ditto. (3rd. section).

113. Ditto. Ditto. (4th. section).

$\left.\begin{array}{c}114 . \\ 115 .\end{array}\right\}$ Strategic Railway - Temporary bridge.

116. General plan of lighthouses and semaphores, to be erected along the Atlantic Coast.

117. Lighthouses and semaphores at the entrance of Bahía Blanca.

118. Lighthouso at Cape de las Tírgenes.

119. Metallic tower for ligthouses.

\section{Photograhps}

\section{A Collection of 62}

$$
\text { (Dimensions: } 30 \times 45 \mathrm{~cm} .=12 " \times 18^{\prime \prime} \text { ) }
$$

1. Strand of Punta Alta - before tire commencement of the works.

2. Building for the waterworks - watch tower.

3. Ditto. Ditto. Ditto.

4. Construction of the concrete platform of the Giring dock.

5. Granite facing up to the first altar.

6. Ditto. Ditto.

7. Southern entrance to the dock - during the construction.

8. Southern entrance to the Graving dock and cngino house. 
9. Erection of the keelblocks and bilge blocks.

10. Erecting the intermediate caisson.

11. Southern entrance at the moment of letting the water in.

12. Northern entrance and view of the works.

13. Taking the floating caisson out and working the slinding caisson.

14. Recess for the sliding caisson.

15. Basin in front of the graving dock.

16. Entrance basin to the graving docks during rough weather.

17. Waves against the sliding caisson.

18. Letting the water into the graving, dock.

19. View of the dock taken as the san Martín» was entering.

20. The first battleship entering the graving dock.

21. The «an Martín breaking the garland.

22. The entrance open after the battleship had entered.

23. Ditto. closed Ditto. Ditto.

24. Floating caisson, which closes up the 3rd. section.

25. Battleship in the dry-stern view.

26. Cieneral view of the docks and Engine house.

27, Cieneral view of the dock after a battleship has left it.

28. Temporary mole at the entrance of the graving dock.

29. Thus in the graving dock.

30. The english cruiser Cambrian» entering the clock.

31. The L.U.S. S. battleship «Iowa» entering the dock.

32. The battleship «lowa in dock, seen from the Northern entrance.

3i. The battleship \&owa in dock, seen from the Southern entrance.

34. The battleship Iowa» in dock, alter the water had been pumper out.

35. Strutting the battleship «lowa» in the graving dock.

36. Stern of the battleship «owa» and Southern entrance to the graving dock.

37. Entineer Villanueva (whom as Minister of War and Marine ordered the construction of the Military Port), at the bottom of the Graving Dock with Admiral sumer of the U. U.S... battleship Lowat. 
38. The battleship «Iowa dry in the dock.

39. Stern of the battleship «Iowa and Engine house.

41. C'ruiser Newark and yacht - Varuna» in the graving'

( dock.

41. Ditto. in the graring dock.

4.. Ditto. seen from the bow in the graving

43. Ditto. in the griving dock.

( dock.

44. The crew of the cruiser Newark drilling.

tó. 'Trainng' ship Samiento» and battleship Pueyrredón s.

46. The training-ship «armiento in the graring dock.

47. Quay wall. Erecting the granite facing.

48. Quay wall in construction.

49. Quay wall. Construction of the subway for the piping.

50. Quay wall in construction.

51 Water Works Building, Watch-tower and Hospital.

5.). General View. Water works Building. Watch tower, and Hospital.

53. Watch tower, and 1st. Section of the Naval Hospital,

54. Panoramic view - Watch tower, Naval Hospital, Engine house, etc.

55. A pavillion of the Naval Hospital.

56. Honse for officials (June 1899 ).

$5 \overline{7}$. House for officials, 3 years after the plantations were finished.

58. School «Humberto $I »$.

59. Railway bridge over the Arroyo Pareja (downstream).

60. Ditto. Ditto. Ditto. (up stream).

61. General view of the maritime works, and anchorage of the fleet.

62. Lighthouse at 《Puntil Alogotes». 



\title{
ARGENTINE REPUBLIC
}

DEPARTMENT OF AGRICULTURE

\section{CAMARA MERCANTIL}

\author{
BARRACAS AL SUD \\ BUENOS AIRES \\ CATA LOGUES
}

These Samples are to be presented after the close of the Exhibition to the Philadelphia Commercial Museum. 


\section{Technical Catalogue of sample case of}

CLASS OF WOOL

DISTRIC T

ZONE

1 Top cross Rambonillet on other merino grades

2

3

4

5

6

7

$\mathrm{S}$

9

10

11

12

13

14

15

16

17

18

19

20

21

22

23

24

25

26

27

28

29

30

31

32

33

34

35

36

Negrete

Rambotillet

$1^{\text {st }}$

$1^{\text {st }}$

, $1^{\text {st }}$

, ,

," ,

, ,

," ,

, ,

", "

, , ,

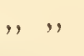

", ",

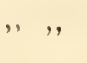

, , ,

, , ,

" ,

, , ,

, 2nd

Fine cross-bred Lincoln

$1^{\text {st }}$

, ,

$$
11
$$

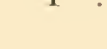

Pueyrredon

Villegas

Chacabuco

,

Azt11

Salto

Pehuajó

Balcarce

Lincoln

Suipaclia

Coronel Vidal

Cañuelas

Olavarría

Azul

Ayacucho

25 de Mayo

Lincoln

Bolivar

San Antonio

Cañuclas

Las Heras

Coronel Vidal

Pringles

Ayacucho

Balcarce

Navarro

Ratuch

Balcarce

Lincolı

Olavarría

Lapricla

Cliascomús
Prov. of Bs. Aires S.

N. IV.

IV.

IV.

S.

N.

IV.

S.

IV.

VI.

S.

S.

S.

S.

S.

S.

S. IV.

IV.

S. IV.

N.

$\mathrm{S}$.

S.

S.

Pampa Central s.

S.

s.

S.

s.

IV.

S.

Panpa Central

S.

s.

II.

s.

s.

s. 


\section{wools forwarded by the Mercantile Chamber}

PASTURE

Fine

Mixed

,

,

",

Fine

Mixed

Fine

Mixed

,

Fine

Mixed

,

,"

Fine

Mixed

,

",

",

Fine

Mixed

Fine

"

Mixed

,

",

Fine

,

Mixed

,

,

Fine

Mixed
ESTIMATE OF YIELD

WHEN SCOURED
SEASON

$E \times H|B| T O R$
Viera Bros.

Fortunato B. Arzeno

Duggan Bros.

Santamarina \& Sons.

Duggan Bros.

Cildoz \& Souza Martinez

José C. de los Santos

Patricio Ham

Cilcloz \& Sonza Martinez

L. Lynch \& Co.

José Crotto \& Sons.

Salaberry, Lalor \& Bercetche

Alejo Gallardo

Fermin Ortiz

Bayona \& Ferrazzini

Cildoz \& Souza Martinez

Patricio Ham

S. Unzué \& Sons.

$45 \%$

$44 \%$

$44 \%$

$45 \%$

$44 \%$

$44 \%$

$4.5 \%$

$4.3 \%$

$43 \%$

$41 \%$

$46 \%$

$47 \%$

$55 \%$

$48 \%$

$49 \%$

$4.8 \%$

$49 \%$
S. Unzae e Sons.

José Crotto \& Sons.

Ojea Garcia \& Co.

L. Lynch \& Co.

S. Unzué \& Sons.

P. \& A. Lanusse

Ramon Yiton

A. Ayerza

Cildoz \& Souza Martine\%

M. Parera Marti

S. Unzuć \& Sons.

Martin Yraizoz

Patricio Ham

Salaberry, Lalor \& Bercetche

Santamarina \& Sons.

Cildoz \& Souza Martinez
José C. de los Santos 


\section{Technical Catalogue of sample case of}

\section{SแMB:R \\ CLASS OF WOOL}

Fine cross-bred Lincoln

38

39

40

41

42

43 Medium cross-bred Lincoln $2^{\text {nd }} / 3^{\mathrm{rd}}$

44 Fine cross-bred Lincoln

45 Medium cross-bred Lincoln

46

47

48

49

50

51

52

53

54

55

56

57

58

59

60

61

62

63

64

65

66

67

68

69

70

$2^{\text {nd }}$
,............. Lobos

Balcarce

Lobería

Laprida

Juarez

Rauch

Olavarría

Las Flores

Magdalena

Dolores

Maipú

Tapalqué

Mercedes

Lincoln

Necochea

Olávarría

Ayacucho

General Alvear

General Guido

Pueyrredon

Balcarce

General Alvear

Dolores

Necochea

Saladillo

Balcatece

Rauch

Alvear

Sitipacha

Lincoln

I'ila

General Saaredra

Balcarce
ZONE

Prov. of Bs. Aires W.

IV.

S.

S.

S.

s.

S.

S.

S.

E.

S.

S.

S.

IV.

IV.

S.

s.

S.

S. W.

S.

S.

s.

S.

S. IV.

s.

S.

S.

IV.

S.

s.

s. W.

IV.

IV.

s.

S. II.

s. 


\section{wools forwarded by the Mercantile Chamber}

PASTURE

Coarse

Mixed

,

,

",

,

",

,

,

\begin{tabular}{l|l}
.,$\quad$ & -1 \\
\hline & -
\end{tabular}

"

",

Fine

Mixed

Coarse

Mixed

Fine

Coarse

Mixed

Fine

Coarse

Mixed

Coarse

Mixed

,"

Coarse.

Mixed

\begin{tabular}{c|c}
,$"$ & $55 \%$ \\
, & $69 \%$ \\
,$"$ & $52 \%$ \\
Fine & $56 \%$
\end{tabular}

$57 \%$

$56 \%$

$55 \%$

64 i

$60 \%$

$50 \%$

$5+\%$

$57 \%$

$66 \%$

$62 \%$

$60 \%$

$52 \%$

$62 \%$

$66 \%$

$60 \%$

$55 \%$

$54 \%$

$57 \%$

$56 \%$

$56 \%$

$57 \%$

$54 \%$

$5 \%$

$69 \%$

$56 \%$
SEASON

EXHIBITOR

Fortunato B. Arzeno

Santamarina \& Sons.

P. E A. Lanusse

Errea \& Urtazun

Salaberry, Lalor \& Bercetche

M. Parera Martí

Bayona \& Ferrazzini

$1903 / 904$

Bang

Viera Bros.

José Crotto \& Sons.

A. Velaz \& Co.

Duggan Bros.

F. Ortiz \& Co.

Salaberry, Lalor \& Bercetche

Martin Yraizoz

J. Crotto \& Sons.

Viera Bros.

M. Yraizoz

José Crotto \& Sons.

Bayona \& Ferrazzini

Salaberry, Lalor \& Bercetche

A. Velaz \& Co.

Santamarina \& Sons.

Reyes Bros.

S. Unzué \& Sons.

Cildoz \& Sotza Martinez

Patricio Ham

P. \& A. Lanusse

Esteban Gotusso

Orcoyen Castaños \& Co. 


\section{Technical Catalogue of sample case of}

DISTRICT

ZONE

73 Fine cross-bred Lincoln $3^{\text {rd }} / 4^{\text {th }}$

74

75 Coarse cross-bred Lincoln

76

77

78

79

so

81

82 Coarse cross-bred Lincoln

83 Medium cross-bred Lincoln

84

85

86

S7

88

S9

90

91

92

93

94

95

96

97

98

99

100

101

102

103

104

105

106

Medium cross-bred Lincoln

4

$4^{\mathrm{t} 1 \mathrm{t}}$

$44^{\text {th }} / 5^{\text {th }}$
Ayacucho

Prov. of Bs. Aires S.
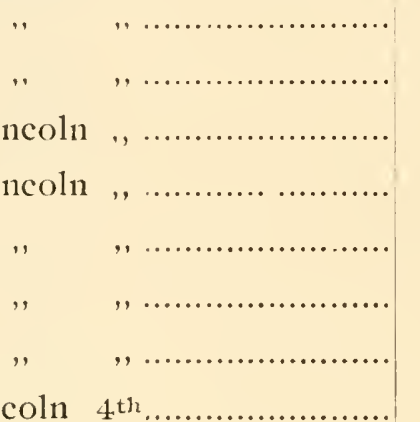

Coarse cross-bred Lincoln $4^{\text {th }}$.

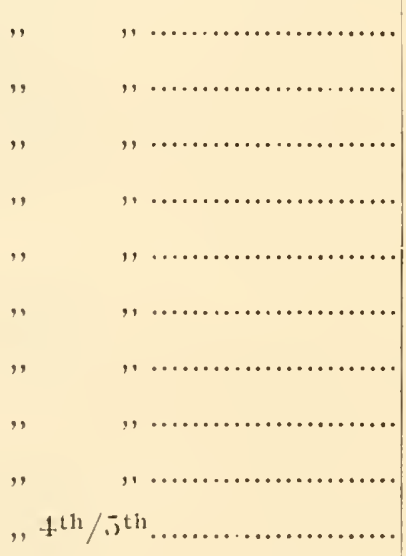
, $4 t^{t h} / 5^{t h}$.

$4^{\text {th }}$.

$5^{\text {th }}$

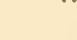

\begin{tabular}{c|ccr} 
Olavarría &, &, & S. \\
I)olores &, &,$"$ & S. \\
Pueyrredon &, &,$"$ & S. \\
Magdalena &, &,$"$ & E. \\
Tres Arroyos &, &,$"$ & S. \\
Lincoln &, &, & W. \\
Mercedes &, &,$"$ & W. \\
Lincoln &, &, & W. \\
Tres Arroyos &, &, & S. \\
Balcarce &, &, & S. \\
Maipú &, &, & S. \\
Tandil &, &, & S.
\end{tabular}

General Alvear

Mercedes

Magdalena

Vecino

Necochea

Lincoln

Maipú

C'hascomús

Tuyú

Ayacucho

Lincoln

Magdalena

Tres Arroyos

Ensenada

Lamadrid

Las Flores

Tuyá
Juarcz
Balcarce
Ayacucho

S. W.

W.

E.

E.

S.

S.

W.

S.

S.

S. E.

S.

W.

E.

E.

S.

E.

S.

S.

S. E.

S.

S.

s. 


\section{wools forwarded by the Mercantile Chamber}

PASTURE

\begin{tabular}{|c|c|}
\hline Fine & $58 \%$ \\
\hline$"$ & $62 \mathrm{r} / \mathrm{r}$ \\
\hline Mixed & $60 \%$ \\
\hline ", & $56 \%$ \\
\hline Fine & $59 \%$ \\
\hline Mixed & $64 \%$ \\
\hline ," & $64 \%$ \\
\hline , & $66 \%$ \\
\hline Fine & $64 \%$ \\
\hline Mixed & $66 \%$ \\
\hline , & $54 \%$ \\
\hline ," & $57 \%$ \\
\hline ," & $64 \%$ \\
\hline ", & $62 \%$ \\
\hline ," & $62 \%$ \\
\hline Fine & $67 \%$ \\
\hline Mixed & $68 \%$ \\
\hline$"$ & $65 \%$ \\
\hline ", & $65 \%$ \\
\hline ," & $66 \%$ \\
\hline , & $64 \%$ \\
\hline , & $62 \%$ \\
\hline ", & $64 \%$ \\
\hline , & $60 \%$ \\
\hline Fine & $62 \%$ \\
\hline Mixed & $67 \%$ \\
\hline , & $68 \%$ \\
\hline$"$ & $67 \%$ \\
\hline , & $67 \%$ \\
\hline ", & 65 " \\
\hline , & $60 \%$ \\
\hline$"$ & $66 \%$ \\
\hline$"$ & $64 \%$ \\
\hline$"$ & $66 \%$ \\
\hline Fine & $67 \%$ \\
\hline " & $66 \%$ \\
\hline
\end{tabular}

SEASON

EXHIBITOR
ESTIMATE OF YIELD

WHEN SCOURED
$1903 / 90$;
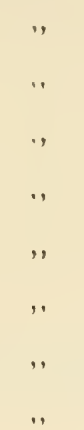


\section{Technical Catalogue of sample case of}

CLASS OF WOOL

109

Coarse cross-bred Lincoln $5^{\text {th }}$

110

111

112

113

114

115

110

117

$11 \mathrm{~s}$

119

120

121 Fine cross-bred Lincoln $2^{\text {nd }}$

122 Top cross Rambouillet on other merino grades $2^{\text {nd }}$

123 Fine cross-bred Lincoln $2^{\text {nd }} / 3^{\text {rd }}$

124

125

126

127

128

129

130

131

132

133

134

135.1190

$13 \mathrm{~A}$

$13 \mathrm{~B}$

$29 \mathrm{~A}$

$29 \mathrm{l3}$

$3 \bar{i}$

35 $\mathrm{B}$

96.1

$2^{\text {nd }}$

Medium cross-bred Lincoln $3^{\text {rd }}$

Top cross Rambouillet on other merino grades $1^{\text {st }}$
DISTRICT

ZONE

Pehuajó

Prov. of Bs. Aires WV.

Magdalena

E.

Ayacucho

Maipú

Ensenada

Lincoln

Balcarce

Nogoyá

Gualeguarchú

Prov. of E. Rios S. IV.

Concordia

S. E.

Gualeguay

Gualeguaychú

Gualeguay

Concordia

Gualeguay

Concordia

Gualeguaycchú

S. E.

S. E.

S. E.

Sauce

Curuzú-Cuatiá

Prov. of Corrientes S.

Sauce

Curuzú-Cuatiá

S. E.

S. E.

S.

S. E.

Sauce

Ayacucho

S. E.

S.

Pror. of Bs. Aires S.

S.

S.
Tres Arroyos

Maipu

Ayacucho

Maipú

San A. de Areco

Pelnuajó

Gualeguay

Tres Arroyos
Maipú
,"
Ayacucho
Maipú
San A. de Arceo
Peluajó
Gualeguay
,,

S.

S.

E.

IV.

S.

.

.

.




\section{wools forwarded by the Mercantile Chamber}

PASTURE

Coarse

Mixed

,
,
,"
,
,
,
,
,
,
,
.,

ESTIMATE OF YIELD

WHEN SCOURED
SEASON

$1903 / 904$

$69 \%$

$68 \%$

$67 c^{\prime}$

$67 \%$

$48 \%$

$67 \%$

$49 \%$

$47 \%$

$48 \%$

$52 \%$

$50 \%$

$52 \%$

$48 \%$

$60 \%$

$53 \%$

$54 \%$

$57 \%$

$56 \%$

$50 \%$

$4.7 \%$

$50 \%$

$48 \%$

$51 \%$

$47 \%$

$48 \%$

Mixed

Tender

Mixed

$42 \%$
$44 \%$

$42 \%$

$46 \%$

$46 \%$

$44 \%$

$64 \%$

$52 \%$

$54 \%$

$56 \%$
EXHIBITOR

Fortunato B. Arzeno

J. Crotto \& Sons.

J. R. Roulriguez \& Son.

Viera Bros.

J. R. Ramsay \& Co.

Patricio Ham

José C. de los Santos

Bernardo Milhas

S. Unzué \& Sons.

Antonio Arzeno \& Co.

Guillermo Kelsey

S. Unzué \& Sons.

Juan B. Mihura

Antonio Arzeno \& Co.

Juan B. Mihura

Antonio Arzeno \& Co.

S. Unzué \& Sons.

Josefa B. de Fonseca

T. Gomez Fonseca

Josefa B. de Fonseca

T. Gomez Fonseca

Josefa B. de Fonseca

Pastor Senillosa

Girat \& Calviño

A. Ayerza

Quintana \& Jauregui

Pedro Argel

Quintana \& Jauregui

Quirno Bros.

Garat \& Calviño

Joaquin Alvarez Bentos 


\section{CATALOGUE OF SHEEPSIKINS}

SIIINS OF WILD ANIMALS

\section{DESCRIPTION OF PRODUCT}

Sheepskin, Slaughtered for ranche use, Cross-bred Lincoln, class $4^{\text {th }}$

1

, ." ."

3

4

5

6

7

8

9

10

11

12

13

14.

15

16 


\section{OX HIDES, HORSE HIDES}

\section{AND BIRDS, AND SUNDRIES}

D I S T R I C T

E X H I B I T O R

Tandil, South of Province of Buenos Aires

Alzaga,

Azul,

Dolores,

Juarez,

Navarro, IVest

Rauch, South

Pila,

Cañuelas,

Maipú,

Olavarría,

Navarro, West

Tandil, South

Alzaga, , ,

Dolores,

Gualeguay, Province of Entre Ríos

La Paz,

Concordia,

Colon,

Gualeguay,

Mercedes, West of Province of Buenos Aires

Tandil, South

Alzaga,

Olascoaga, West

Alzaga, South

Juarez,
Santamarina \& Sons.

S. Unzué \& Sons.

Santamarina \& Sons.

Fortunato B. Arzeno.

José Crotto \& Sons.

Angel Vélaz \& Co.

Fortunato B. Arzeno.

Orcoyen, Castaños \& Co.

José Crotto \& Sons.

Santamarina \& Sons.

Angel Velaz \& Co.

Santamarina \& Sons.

S. Unzué \& Sons.

José Crotto \& Sons.

Angel Vélaz \& Co.

Antonis Arzeno \& Co.

Juan B. Mechura.

Angel Vélaz \& Co.

Cildoz \& Souza Martiner.

F. B. Arzeno.

s. Unzué \& Sons.

Ginocchio, Etchererry \& Co.

F. B. Arzeno.

Angel Vélaz \& Co. 


\section{$\mathrm{N}^{\circ}$ \\ DESCRIPTION OF PRODUCT}

Ox hide, slaughtered for use on ranche.

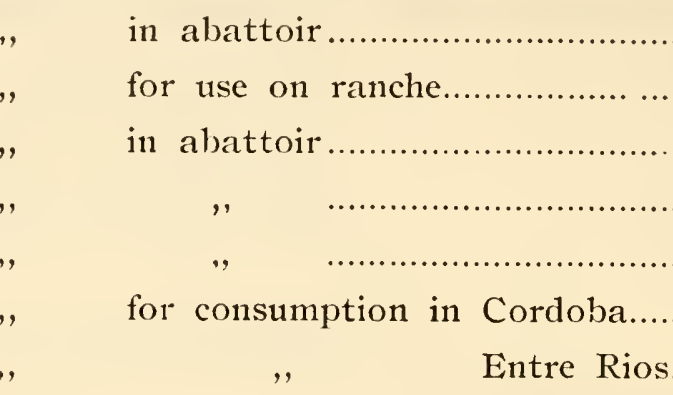

Calf skin.

Unborn calf's skin.

Horse hide, male.

Horse hide, female.

Goat skin

Horse tail, docked.

,, undocked.

$6 \mathrm{cow}$ tails

8 horse tails docked.

8 bundles mane horse hair...

1 bundle pigs bristles.

South American Ostrich feathers (Rhea) light coloured

2

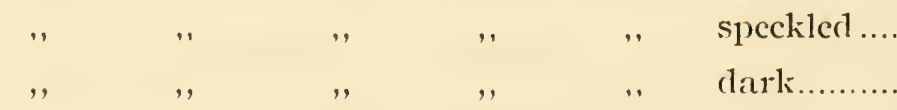

, " , , ,

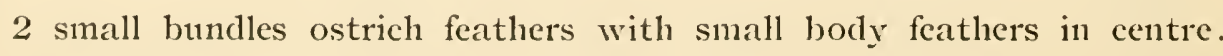
Scoured and carded merino wool. 


\section{OX HIDES, HORSE $\sim$ HIDES}

\section{AND BIRDS, AND SUNDRIES}

D I S T R I C T

Arrecifes, South of Province of Entenos Aires

Navarro,

Dolores,

Maipú,

Province of Cordoba

$$
\text { , , Entre Ríos }
$$

Dolores, South of Province of Buenos Aires

Tandil,

Dolores,

Alzaga,

Junin, West of Province of Buenos Aires

Province of Cordoba

Province of Buenos Aires

South of Province of Buenos Aires

Argentine Republic
Angel Vélaz \& Co.

José Crotto \& Sons.

Ramon Sisto.

Victoriano Villamil.

Angel Vélaz \& Co.

José Crotto \& Sons.

Fortunato B. Arzeno.

José Crotto \& Sons.

S. Unzué \& Sons.

Cildoz \& Souza Martinez.

Orcoyen Castaños \& Co.

Cildoz \& Souza Martinez.

S. Unzué \& Sons.

Victoriano Villamil.

Angel Vélaz \& Co.

Victoriano Villamil.

Angel Gonzalez \& Son.

Mereantile Chamber 


\section{Technical Catalogue of Products of the}

No.

DESCRIPTION OF PRODUCT

Fox skin (Canis magellanicus)

(Canis Azaræ)

Skunk skin (Mephitis Patagonicus)

Swan's skin (Cygnus nigricollis)

Wild cat skin (Felis Geoffroyi)

Stag skin

Deer slin

Goat slin

Kid skin

Water log skin (H. Capybara)

Chajá skin (Palanıedea Chavaria)

Possum skin (Didlelphys Azara)

Grey Monkey skin"

Otter skin, so called, (Myopatamis Coypus)

Marmot skin

(unsplit).

Wild" cat skin (Felis pajeros Azara)

Cormorant slin (Carbo Brasiliensis)

Pampa Hare "skin (Dolichotis patagonica).

Rabbit skin

Penguin skin

Water Boa

Tiger cat slin...

Young chajá skin...

Cliajá skin..

Unborn calf skin, salted

Chinchilla skin (Chincilla lanigera) 


\section{Chase, exhibited by the Mercantile Chamber}

DISTRICT

Patagones, National Territory.

Pigüé, Province of Bnenos Aires

Puan,

Patagones, National Territory.

Dolores, Province of Buenos Aires

Tornquist,

Pampa Central, National Territory

Alzaga, Province of Buenos Aires...

Province of "Córdoba

Corrientes

Dolores, Province of Buenos Aires

Province of Corrientes

Chaco, National "Territory...

Dolores, Province of Buenos Aires

Province of Entre Rios

Pampa Central, National Territory

Province of "Corrientes

Puan, Province of Buemos Aires

Santa Cruz, National Territory

Provinee of Corrientes

Chaco, National Territory...

Ayacucho, Province of buenos Aires

Province of Buenos Aires

$$
\text { , , Salta }
$$

Chaco, National Territory

Cañuelas, Province of Buenos Aires
$E \times H|B| T O R$

Mercantile Chamber.

A. Caride, Jr. Bro. \& Co. Mereantile Chamber.

A. Caride, Jr. Bro. \& Co.

$\begin{array}{lllll}, " & , & , & , & , \\ , " & , & , & , & , \\ , & , & , & , & , \\ , & , & , & , & , "\end{array}$

Mereantile Chamber.

A. Caride, Jr. Bro. \& Co.

Mercantile Chamber.

Mlonso and Blaquier.

Ger"inan Nolte.

Mercantile Chamber. 




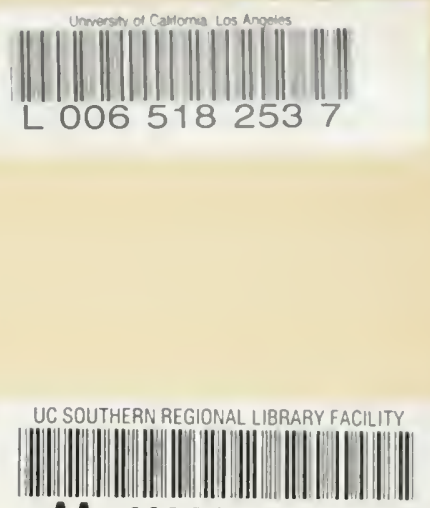

AA 0007230568

SOUTHERN REersity of California

305 De Neve Drive - Parking LIBRARY FACILITY

LOS ANGELES, CALIFO Lot 17 • Box 951388

Return this material to the CALIFORNIA 90095-1388

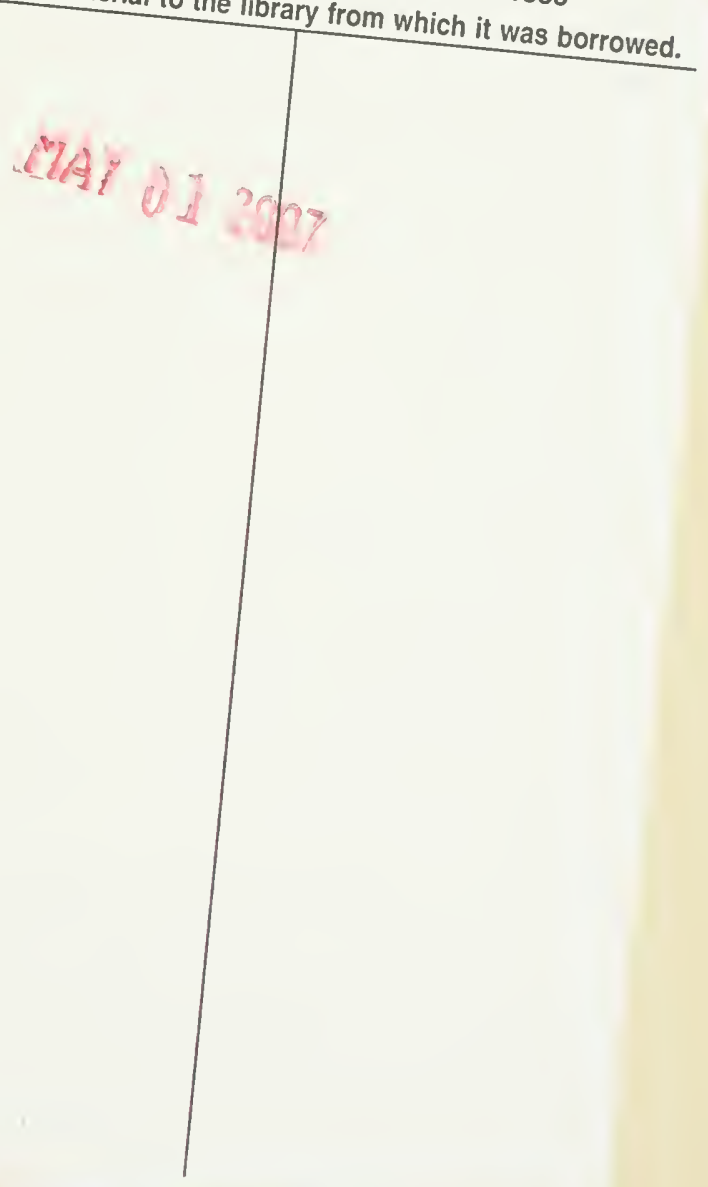


lifornia fional ility 